UNIVERSIDADE DE SÃO PAULO

FACULDADE DE ECONOMIA, ADMINISTRAÇÃO E CONTABILIDADE DE RIBEIRÃO PRETO

DEPARTAMENTO DE ADMINISTRAÇÃO

\title{
A INFORMAÇÃO COMO FATOR CHAVE PARA ATUAÇÃO NO MERCADO INTERNACIONAL: UM ESTUDO PILOTO COM EMPRESAS EXPORTADORAS DE RIBEIRÃO PRETO E REGIÃO
}

ORLIENE MACIEL GUIMARÃES

Orientador: Professor Doutor Dirceu Tornavoi de Carvalho

RIBEIRÃO PRETO 
Prof $^{\mathrm{a}}$. Dr ${ }^{\mathrm{a}}$. Suely Vilela

Reitora da Universidade de São Paulo

Prof. Dr. Rudinei Toneto Júnior

Diretor da Faculdade de Economia, Administração e Contabilidade.

Prof. Dr. Marcio Mattos Borges de Oliveira

Chefe do Departamento de Administração

Prof. Dr. André Lucirton Costa

Coordenador do Programa de Pós-Graduação em Administração 
ORLIENE MACIEL GUIMARÃES

\title{
A INFORMAÇÃO COMO FATOR CHAVE PARA ATUAÇÃO NO MERCADO INTERNACIONAL: UM ESTUDO PILOTO COM EMPRESAS EXPORTADORAS DE RIBEIRÃO PRETO E REGIÃO
}

\begin{abstract}
Dissertação apresentada ao Mestrado do Programa de Pós-Graduação em Administração de Organizações do Departamento de Administração da Faculdade de Economia. Administração e Contabilidade de Ribeirão Preto da Universidade de São Paulo.
\end{abstract}

Orientador: Prof. Dr. Dirceu Tornavoi de Carvalho

\section{RIBEIRÃO PRETO}


AUTORIZO A REPRODUÇÃO E DIVULGAÇÃO TOTAL OU PARCIAL DESTE

TRABALHO, POR QUALQUER MEIO CONVENCIONAL OU ELETRÔNICO, PARA FINS DE ESUDO E PESQUISA, DESDE QUE CITADA A FONTE.

\section{FICHA CATALOGRÁFICA}

Guimarães, Orliene Maciel

A informação como fator chave para atuação no mercado internacional: Um estudo piloto com empresas exportadoras de Ribeirão Preto e Região./Orliene Maciel Guimarães - São Paulo. 2007.

$159 \mathrm{pg}$

Dissertação (Mestrado - Programa de Pós-Graduação em Administração de Organizações) - Faculdade de Administração Economia e Contabilidade de Ribeirão Preto da Universidade de São Paulo.

1. Exportação. 2. Inserção Internacional. 3. Informação de Mercado. 4. Marketing Internacional 


\section{FOLHA DE APROVAÇÃO}

Orliene Maciel Guimarães

Título: A INFORMAÇÃO COMO FATOR CHAVE PARA ATUAÇÃO NO MERCADO INTERNACIONAL: UM ESTUDO PILOTO COM EMPRESAS EXPORTADORAS DE RIBEIRÃO PRETO E REGIÃO

Dissertação apresentada à Faculdade de Administração Economia e Contabilidade de Ribeirão Preto da Universidade de São Paulo para obtenção do título de Mestre em Administração de Organizações.

Aprovado em:

Banca Examinadora

Prof. Dr.

Instituição: Assinatura:

Prof. Dr.

Instituição: Assinatura:

Prof. Dr.

Instituição: Assinatura: 


\section{AGRADECIMENTOS}

A Deus, Supremo Criador do Universo, que permitiu a concretização de um sonho há muito acalentado.

Aos meus pais, pela graça da vida e formação do meu caráter, fundamentais para que eu chegasse até aqui.

Aos amigos que me acompanharam durante o curso de mestrado, pela convivência, paciência, colaboração e incentivo.

As empresas participantes desta pesquisa, cujos funcionários gentilmente cederam seu precioso tempo no preenchimento do questionário.

A Faculdade de Administração Economia e Contabilidade da Universidade de São Paulo, Campus de Ribeirão Preto, representada pelo Prof. Dr. Dirceu Tornavoi de Carvalho, pela oportunidade de realização do curso de mestrado e pelo seu apoio, orientação e intervenções fundamentais neste trabalho. 
“Quem pode exportar?

Quem avaliou sua capacidade de internacionalização e encara a exportação como uma estratégia para melhorar a competitividade." 


\section{RESUMO}

GUIMARÃES, O.M. A informação como fator chave para atuação no mercado internacional: um estudo piloto com empresas exportadoras de Ribeirão Preto e região. 2007. Dissertação de Mestrado. Faculdade de Economia, Administração e Contabilidade de Ribeirão Preto, Universidade de São Paulo, Ribeirão Preto, 2007.

A participação das empresas brasileiras no comércio internacional vem aumentando nos últimos anos. Neste contexto, pesquisas foram conduzidas visando detectar as dificuldades associadas à atividade exportadora, e a literatura sugere a necessidade de informação para uma atuação bem sucedida no cenário internacional. Esta pesquisa objetiva identificar as informações, utilizadas por empresas exportadoras em sua atividade exportadora, levantadas a partir da revisão bibliográfica. Para tal, desenvolveu-se uma pesquisa de campo com empresas exportadoras da região de Ribeirão Preto. Os resultados mostraram que as empresas utilizam pouco as informações gerais do ambiente de negócios internacionais e com mais frequiência as informações do mercado alvo, ligadas a oferta/demanda do produto. Quanto às fontes de informação, observou-se que grande parte é obtida do próprio cliente. Também foi possível observar que as empresas com maior volume de exportação tendem a desenvolver mais o processo de utilização de informação para a geração de novos negócios, atuam em mercados mais exigentes, diversificam sua forma de atuação e buscam constantemente novos mercados.

Palavras-chave: Exportação. Pequenas e Médias Empresas. Informação de Mercado. Comércio Internacional. 


\begin{abstract}
GUIMARÃES, O.M.. 2007. The information as a key factor for participating in the international marketing: a pilot study with Ribeirão Preto Region's exporting companies. Faculdade de Economia, Administração e Contabilidade de Ribeirão Preto, Universidade de São Paulo, Ribeirão Preto, 2007.
\end{abstract}

The Brazilian companies' international commerce participation has been increasing in recent years. Within this context, research were carried with objective of identify the difficulties associated to exporting activities, as well the companies which recognize information as a need to a successful international market actuation. This research focused the information used by exporting companies in their export activities, raised from the bibliographic revision. In order to do so, a field survey was developed with Ribeirão Preto Region's exporting companies. The results showed that the companies use little general international business environment information and, with higher frequency, the target market information, linked to product's offer/demand. Regarding to information source, was observed that most of it was obtained directly with customer. It was also possible to observe that companies with higher volume of exporting tend to develop better information system in order to generate new business, act in more demanding markets, diversify its form of performance and search new markets constantly.

Key words: Exporting. Small and Medium Companies. Market Information. International Commerce. 


\section{SUMÁRIO}

LISTA DE ABREVIATURAS E SIGLAS.............................................................. 03

LISTA DE QUADROS................................................................................... 04



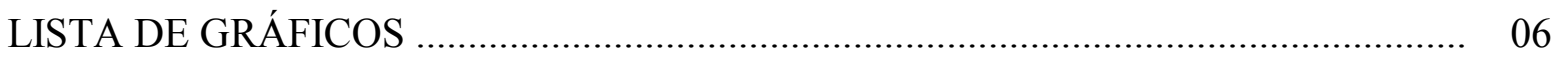

1. O PROBLEMA DE PESQUISA...................................................................... 08

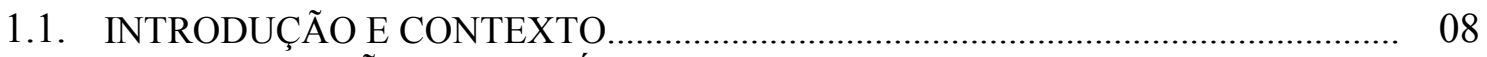

1.1.1. EVOLUÇÃO DO COMÉRCIO INTERNACIONAL ........................................ 08

1.1.2. A PARTICIPAÇÃO DO BRASIL NO COMÉRCIO INTERNACIONAL........ 12

1.1.3. AS EMPRESAS BRASILEIRAS NO CENÁRIO INTERNACIONAL ............. 14

1.2. FORMULAÇÃO DO PROBLEMA......................................................................... 20

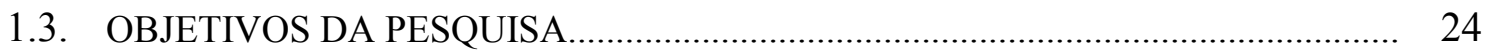

1.4 JUSTIFICATIVA, IMPORTÂNCIA E CONTRIBUIÇÕES DO ESTUDO................ 25

1.5 DELIMITAÇÕES DO ESTUDO.......................................................................... 26

2. REVISÃO DA LITERATURA....................................................................... 28

2.1 AS ESTRATÉGIAS DE INSERÇÃO NO MERCADO INTERNACIONAL............ 28

2.1.1. O MODELO UPPSALA ........................................................................ 29

2.1.2. O PROCESSO DE INSERÇÃO INTERNACIONAL..................................... 32

2.2 INFORMAÇÕES PARA TOMADA DE DECISÃO SOBRE ATUAÇÃO NO MERCADO EXTERNO.............................................................................. 36

2.2.1. INTELIGÊNCIA DE MERCADO PARA ALTA GERÊNCIA........................ 39

2.2.2.MODELO DE INTELIGÊNCIA DE MERCADO INTERNACIONAL DE KEEGAN

2.2.3. MODELO DE INTELIGÊNCIA DE MERCADO INTERNACIONAL DE DOWLE \& LOWE.

2.2.4. MODELO DE INTELIGÊNCIA DE MERCADO INTERNACIONAL DE HILL. . .

2.2.5. INTELIGÊNCIA DE MERCADO INTERNACIONAL APLICADO AO COMÉRCIO EXTERIOR BRASILEIRO.............................................................. 48

2.3 O AMBIENTE DE NEGÓCIOS INTERNACIONAIS............................................. 49

2.3.1. O AMBIENTE SÓCIO CULTURAL ……...................................................... 50

2.3.2. O AMBIENTE ECONÔMICO.......................................................................... 51

2.3.3. O AMBIENTE POLÍTICO LEGAL E REGULATÓRIO................................ 51

2.3.4. O AMBIENTE TECNOLÓGICO................................................................. 52

2.4 INFORMAÇÕES REQUERIDAS PARA OS NEGÓCIOS INTERNACIONAIS..... 54

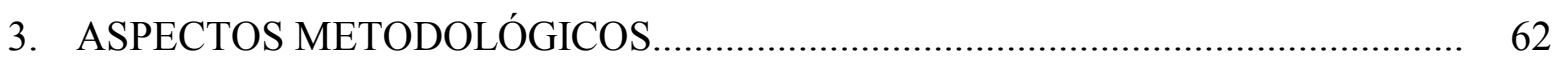

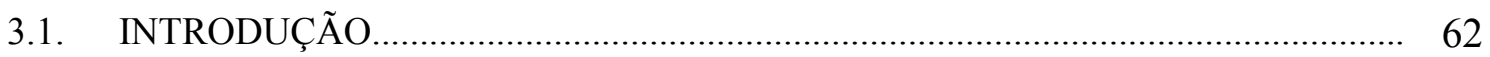

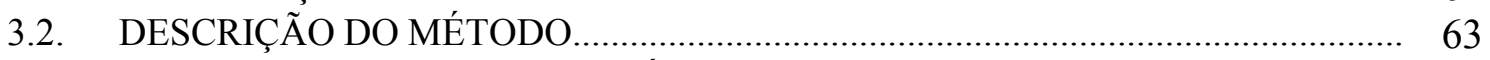



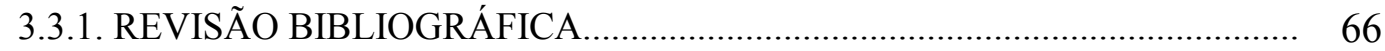

3.3.2. DELIMITAÇÃO DO ESTUDO DE CAMPO................................................... 67 
3.3.3. ELABORAÇÃO DO QUESTIONÁRIO....................................................... 70

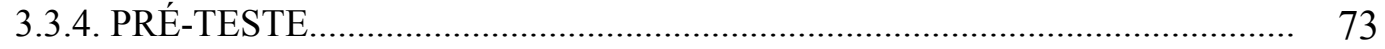

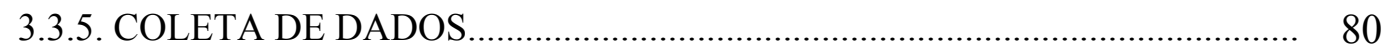

3.3.6. ANÁLISE DOS DADOS............................................................................... 82

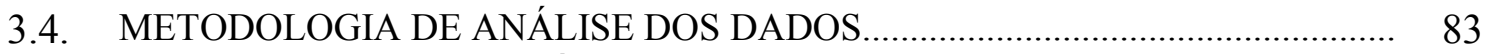

3.5. LIMITAÇÕES METODOLÓGICAS................................................................. 84

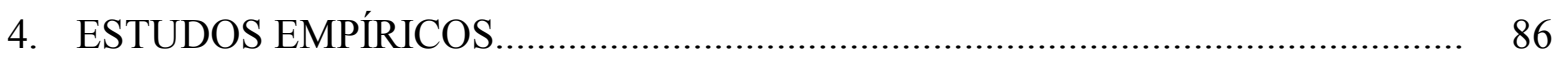

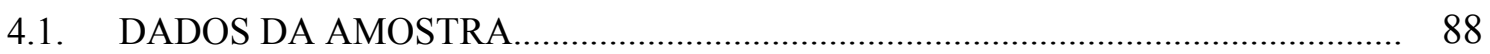

4.1.1. CARACTERÍSTICAS DA AMOSTRA.................................................... 88

4.1.2. MERCADOS DE ATUAÇÃO ….................................................................... 93

4.1.3. PERFIL DE ATUAÇÃO ............................................................................... 95

4.2. INFORMAÇÕES SOBRE OS PAÍSES ALVO .................................................... 96

4.2.1. USO DE INFORMAÇÕES GERAIS............................................................... 96

4.2.2. USO DE INFORMAÇÕES DE MERCADO.................................................. 100

4.3. FONTES DE INFORMAÇÃO SOBRE OS PAÍSES ALVO...................................... 107

4.3.1. ANÁLISE FATORIAL DO USO DAS FONTES DE INFORMAÇÕES......... 108

4.4. ANÁLISE DOS DADOS................................................................................... 111

4.4.1. TEMPO DE EXPERIÊNCIA X VOLUME DE EXPORTAÇÃO...................... 111

4.4.2. TEMPO DE EXPERIÊNCIA X QUANTIDADE DE MERCADOS................ 112

4.4.3. ANÁLISE DA DIFERENÇA ENTRE GRUPOS........................................... 113

5. CONCLUSÕES E CONSIDERAÇÕES FINAIS ................................................. 123

6. CONTRIBUIÇÕES E RECOMENDAÇÕES PARA PESQUISAS FUTURAS........ 126

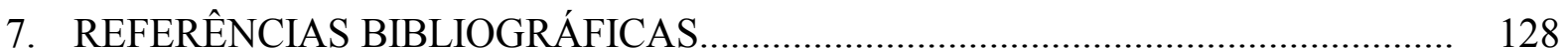

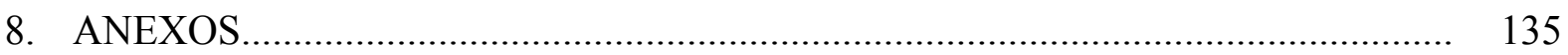

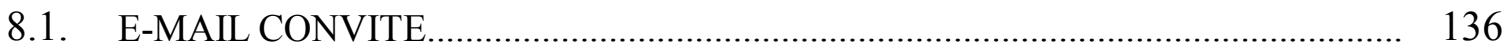

8.2. INSTRUMENTO DE PESQUISA - QUESTIONÁRIO............................................. 137

8.3. RELAÇÃO DAS EMPRESAS EXPORTADORAS DA REGIÃO............................. 140

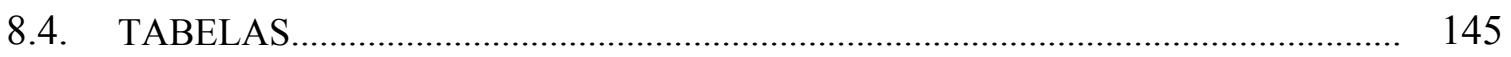




\section{LISTA DE ABREVIATURAS E SIGLAS}

AAP

$\mathrm{ACE}$

ALADI

ALALC

BNDES

CNPJ

DEPLA

FUNCEX

GATT

GMC

IEDI

MERCOSUL

MDIC

$\mathrm{OMC}$

PIB

PME

SACU

SEBRAE

SECEX

SISCOMEX

Acordo de Alcance Parcial

Acordo de Complementação Econômica

Associação Latino Americana de Integração

Associação Latino Americana de Livre Comércio

Banco Nacional de Desenvolvimento Econômico e Social

Cadastro Nacional de Pessoas Jurídicas

Departamento de Planejamento e Desenvolvimento do Comércio Exterior Fundação Centro de Estudos em Comércio Exterior

General Agreement for Trade and Tariffs

Grupo Mercado Comum

Instituto de Estudos para o Desenvolvimento Industrial

Mercado Comum do Sul

Ministério do Desenvolvimento, Indústria e Comércio Exterior

Organização Mundial do Comércio

Produto Interno Bruto

Pequenas e Médias Empresas

South African Custom Union

Serviço Brasileiro de Apoio às Micro e Pequenas Empresas

Secretaria de Comércio Exterior

Sistema Informatizado de Comércio Exterior 


\section{LISTA DE QUADROS}

Quadro 1- Teorias do Comércio Internacional

Pág. 28

Quadro 2- Estágios de Desenvolvimento na Exportação

Pág. 34

Quadro 3- Modelo de Sistema de Inteligência Internacional de Keegan

Pág. 41

Quadro 4- Modelo de Análise de Mercado Internacional de Dowle \& Lowe

Pág. 44

Quadro 5- Inteligência de Mercado Internacional de Hill

Pág. 46

Quadro 6- Ambiente de Negócios Internacionais

Pág. 54

Quadro 7- Visão macro do universo de informações

Pág. 55

Quadro 8- Sumário de Informações Necessárias

Pág. 57

Quadro 9- Informações teoricamente relevantes para as atividades internacionais

Pág. 60

Quadro 10- Detalhamento do Questionário

Pág. 74

Quadro 11- Características da Empresa

Pág. 75

Quadro 12- Mercados de Atuação

Pág. 75

Quadro 13- Perfil de Atuação

Pág. 76

Quadro 14- Informações Gerais dos países

Pág. 77

Quadro 15- Informações sobre o Mercado Alvo

Pág. 78

Quadro 16- Linha de Resposta do Questionário

Pág. 79

Quadro 17- Fontes de Informação

Pág. 79

Quadro 18- Informações sobre o Respondente

Pág. 80

Quadro 19- Quadro Resumo das Conclusões do Trabalho

Pág. 122 


\section{LISTA DE TABELAS}

Tabela 1- Acordos Internacionais Negociados pelo Brasil 1990-2005

Pág. 10

Tabela 2- Classificação das Empresas Exportadoras

Pág. 17

Tabela 3- Volume de Exportações por tamanho de empresa 2002 a 2005

Pág. 18

Tabela 4- No. de Empresas x Volume Exportado 2002-2005

Pág. 18

Tabela 5- Maiores dificuldades associadas à atividade exportadora

Pág. 20

Tabela 6- Fatores mais importantes para o sucesso de uma empresa

Pág. 21

Tabela 7- Grau de Dificuldade em relação aos fatores exigidos pela experiência exportadora

Pág. 22

Tabela 8- Dificuldades Associadas à atividade exportadora por tamanho de empresa

Pág. 23

Tabela 9- Dificuldades Associadas à atividade exportadora por freqüência exportadora

Pág. 23

Tabela 10- Exportação Brasileira - Distribuição por porte de empresa

Pág. 68

Tabela 11- Representatividade das empresas exportadoras de São Paulo

Pág. 68

Tabela 12- Plano Amostral

Pág. 69

Tabela 13- Amostra selecionada para coleta de dados

Pág. 81

Tabela 14- Resultado da Seleção dos Questionários

Pág. 86

Tabela 15- Uso de Informações Gerais

Pág. 96

Tabela 16- Uso de Informações de Mercado

Pág. 100

Tabela 17- Informações sobre o Mercado Alvo por ordem de citação

Pág. 101

Tabela 18- Escala do Volume de Exportações

Pág. 111 


\section{LISTA DE GRÁFICOS}

Gráfico 1- Evolução das Exportações Mundiais de 1950-2006

Pág. 9

Gráfico 2- Variação Anual das Exportações x Variação Anual do PIB 20022004

Pág. 11

Gráfico 3- Participação do Brasil nas Exportações Mundiais (1950-2006)

Pág. 13

Gráfico 4- Empresas Brasileiras Exportadoras 1990-2005

Pág. 15

Gráfico 5- Volume Exportado por tamanho de empresa 2002-2005

Pág. 15

Gráfico 6- Representatividade Amostral

Pág. 70

Gráfico 7- $\quad$ Ano de Fundação da empresa

Pág. 88

Gráfico 8- Número de Funcionários

Pág. 89

Gráfico 9- Receita Anual com Exportação

Pág. 90

Gráfico 10- Participação das Exportações no Volume de Vendas Totais Anuais

Pág. 90

Gráfico 11- Setores de Atuação das Empresas Respondentes

Pág. 91

Gráfico 12- Experiência das Empresas com Exportação

Pág. 92

Gráfico 13- Primeira Exportação - País

Pág. 93

Gráfico 14- Mercados de Atuação das Empresas da Região

Pág. 94

Gráfico 15- Perfil de Atuação das Empresas Respondentes

Pág. 95

Gráfico 16- Perfil de Atuação no Mercado Internacional

Pág. 96

Gráfico 17- Fontes de Informação utilizadas pelas empresas respondentes

Pág. 107 


\section{LISTA DE FIGURAS}

Figura 1- Dinâmica do Modelo Uppsala

Pág. 31

Figura 2- Etapas da Inserção Internacional de Empresas

Pág. 33

Figura 3- Organização da Divisão do Serviço de Inteligência

Pág. 39

Figura 4- Análise Internacional de Mercados de Hill

Pág. 45

Figura 5- Influências do ambiente no marketing internacional

Pág. 49

Figura 6- Etapas da Pesquisa

Pág. 65

Figura 7- Etapas para seleção da amostra

Pág. 69

Figura 8- Modelo conceitual de Pesquisa

Pág. 72

Figura 9- Teste $K M O$ - Uso de Informações Gerais

Pág. 98

Figura 10- Matriz de Variância Total Explicada - Uso de Informações Gerais

Pág. 98

Figura 11- Matriz de Componentes Principais - Uso de Informações Gerais

Pág. 99

Figura 12- Teste $K M O$ - Uso de Informações de Mercado

Pág. 102

Figura 13- Matriz de Variância Total Explicada - Uso de Informações de Mercado

Pág. 103

Figura 14- Matriz de Componentes Principais - Uso de Informações de Mercado

Pág. 104

Figura 15- Resultado do Texto KMO - Uso de Informações de Mercado

Pág. 105

Figura 16- Resultado da Variância Total Explicada - Uso de Informações de Mercado

Pág. 105

Figura 17- Matriz de Componentes Rotacionada - Uso de Informações de Mercado

Pág. 106

Figura 18- Teste $K M O$ - Fontes de Informações sobre o País Alvo

Pág. 108

Figura 19- Variância Total Explicada - Fontes de Informação sobre o País Alvo

Figura 20- Matriz dos Componentes Principais - fontes de Informação sobre o País Alvo

Pág. 109

Pág. 109

Figura 21 - Matriz de Correlação: Tempo de Experiência x Volume de Exportação

Pág. 112

Figura 22- Matriz de Correlação: Tempo de Experiência x Quantidade de Mercados

Pág. 112

Figura 23- Histograma: No. De Anos que a empresa exporta

Pág. 120 


\section{Problema de Pesquisa}

\subsection{Introdução e Contexto}

\subsubsection{Evolução do Comércio Internacional}

O comércio internacional é parte integrante do desenvolvimento das nações, pois trata das relações de compra, venda e troca de mercadorias e serviços que geram parte do fluxo internacional de capitais. Foi a partir do século XVI e metade do século XVIII, período da Revolução Industrial, que as bases conceituais começaram a se desenvolver e se tornaram fonte de estudos teóricos da ciência econômica (DIAS et al. 2004; SOARES, 2004; AMARAL, 2004).

A busca por novos mercados, a partir do século XVIII, faz surgir idéias do livre comércio em favor de um maior bem estar para a população, que se beneficiaria de produtos originários de outros países. O crescimento do comércio internacional impôs às nações necessidade de associarem-se e combaterem as práticas abusivas, o que fez surgir, em 1947, os acordos internacionais, visando regulamentar as relações comerciais internacionais, por meio do GATT (General Agreement for Trade and Tariffs). A partir desta época, muitas nações, com o objetivo de incrementar o comércio e reduzir as barreiras, começaram a se unir, na formação de acordos internacionais e blocos econômicos.

A partir de 1995, o GATT foi base para a criação da OMC (Organização Mundial do Comércio), propondo uma flexibilidade comercial maior entre os membros e regras mais claras na solução de controvérsias. 
O efeito do esforço conjunto ao longo de décadas resultou em grande expansão nas trocas entre as nações. A evolução do comércio internacional pode ser visualizada no Gráfico 1, que retrata as exportações mundiais, a partir de 1950 até 2006.

Gráfico 1: Evolução das Exportações Mundiais de 1950-2006

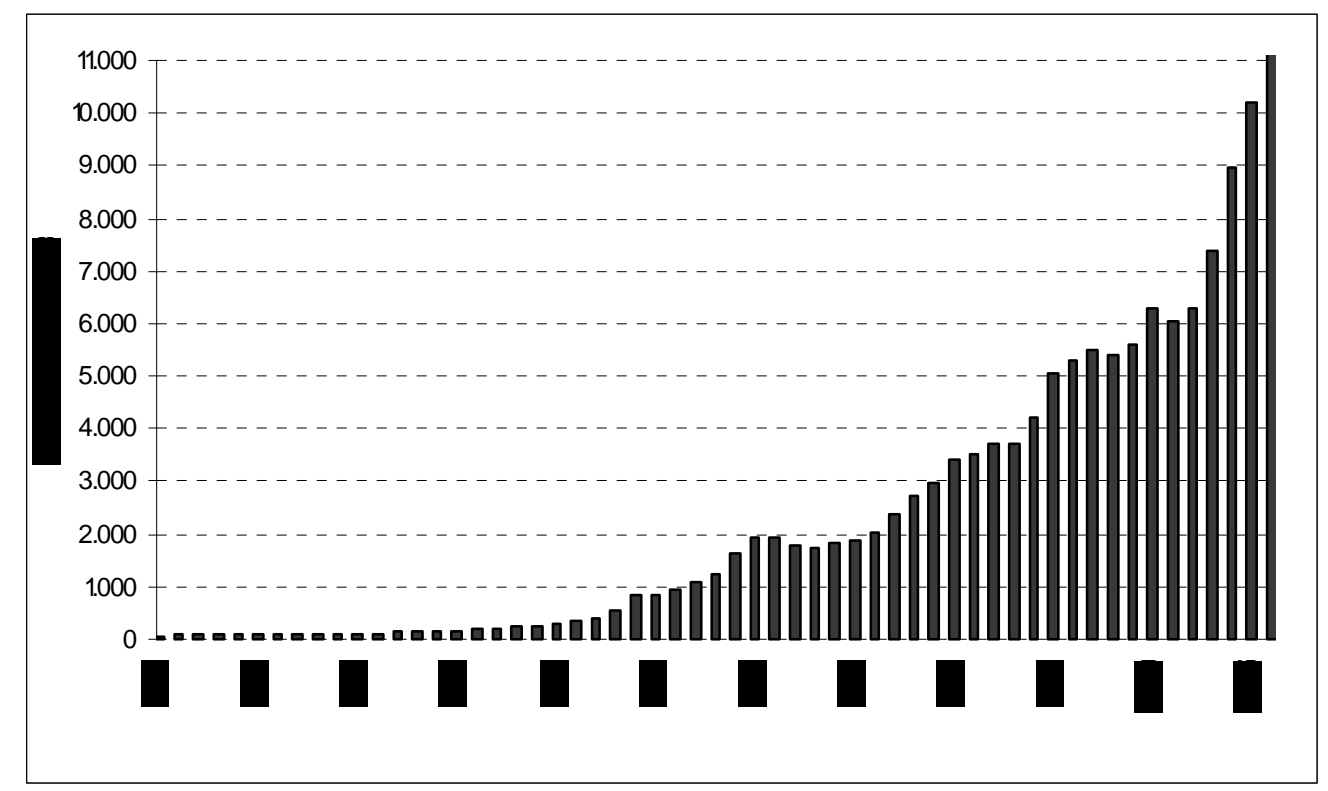

FONTE: Ministério do Desenvolvimento, 2006.

Pode-se observar no Gráfico 1 que, a partir de meados dos anos 70, o comércio internacional alcançou uma evolução crescente. A partir dos anos 90, a abertura comercial e o aumento dos acordos comerciais desenvolvidos pelas nações, com a criação da OMC, refletiu um aumento no volume do comércio internacional.

A assinatura de acordos comerciais bilaterais é uma característica da atualidade vem resultando em muitos blocos econômicos numa multiplicidade de regras para o comércio internacional. O Brasil participa desta tendência ativamente resultando na sua atuação como integrante de bloco econômico data de 1960, quando sete países criaram Associação LatinoAmericana de Livre Comércio (ALALC), transformada em Associação Latino-Americana de Integração (ALADI) em 1980. 
Tabela 1 - Acordos Internacionais Negociados pelo Brasil, 1990-2005

\begin{tabular}{|c|c|c|c|}
\hline Participantes & Acordo $^{1}$ & $\overline{\text { Data }^{2}}$ & Objetivos \\
\hline Brasil - Uruguai & ACE 2 & $20 / 06 / 83^{3}$ & $\begin{array}{l}\text { Regular o comércio de produtos } \\
\text { automotivos }\end{array}$ \\
\hline Brasil - Argentina & ACE 14 & $15 / 03 / 91^{4}$ & $\begin{array}{l}\text { Regular o comércio de produtos } \\
\text { automotivos }\end{array}$ \\
\hline Brasil - MERCOSUL & ACE 18 & $21 / 11 / 91$ & Criar o Mercado Comum do Sul \\
\hline MERCOSUL - Chile & ACE 35 & $19 / 11 / 96$ & $\begin{array}{l}\text { Criar Zona de Livre Comércio em dez } \\
\text { anos }\end{array}$ \\
\hline MERCOSUL - Bolívia & ACE 36 & $28 / 05 / 97$ & $\begin{array}{l}\text { Criar Zona de Livre Comércio em dez } \\
\text { anos }\end{array}$ \\
\hline Brasil - Peru $^{5}$ & ACE 39 & $16 / 08 / 99$ & Criar Zona de Livre Comércio \\
\hline Brasil - Cuba & ACE 43 & $22 / 03 / 00$ & Dinamizar o Comércio Bilateral \\
\hline Brasil - México & ACE 53 & $23 / 09 / 02$ & Dinamizar o Comércio bilateral \\
\hline MERCOSUL - México & ACE 54 & $18 / 02 / 03$ & Criar Zona de Livre Comércio \\
\hline MERCOSUL - Canadá ${ }^{5}$ & ACE 59 & $02 / 02 / 05$ & Criar Zona de Livre Comércio \\
\hline Brasil - Trinidad Tobago & AAP-A25TM & $07 / 03 / 02$ & $\begin{array}{l}\text { Promover o incremento do Comércio } \\
\text { Bilateral }\end{array}$ \\
\hline Brasil - Guiana & $\begin{array}{l}\text { AAP-A25TM no. } \\
38\end{array}$ & $31 / 05 / 04$ & $\begin{array}{l}\text { Promover o incremento do Comércio } \\
\text { Bilateral }\end{array}$ \\
\hline Brasil - Suriname & ACE-41 & $31 / 05 / 04$ & $\begin{array}{l}\text { Concessão de quota anual para } \\
\text { importação de arroz }\end{array}$ \\
\hline MERCOSUL -SACU $^{6}$ & & $16 / 12 / 04^{7}$ & Criar Zona de Livre Comércio \\
\hline MERCOSUL - Índia & & $19 / 03 / 05^{7}$ & Criar Zona de Livre Comércio \\
\hline
\end{tabular}

${ }^{1}$ ACE (Acordo de Complementação Econômica); AAP (Acordo de Alcance Parcial); A25TM (Artigo 25 do Tratado de Montevidéu).

${ }^{2}$ Data de internalização na legislação brasileira.

${ }^{3} 60$ o Protocolo adicional foi internalizado no Brasil em 06/06/03.

${ }^{4} \mathrm{O} 31$ o Protocolo adicional foi internalizado no Brasil em 11/11/02.

${ }^{5}$ O ACE 39 incluía também Colômbia, Equador e Venezuela que, com o Peru, formam a Comunidade Andina. Os três primeiros firmaram o ACE 59 com o MERCOSUL.

${ }^{6}$ SACU (South African Customs Union) inclui África do Sul, Lesoto, Namíbia, Botswana e Suazilândia.

${ }^{7}$ Data do acordo de preferências tarifárias. Aguarda-se a internalização do Acordo para entrada em vigor.

Fonte: <http://www.desenvolvimento.gov.br/sitio/secex/negInternacionais/acoComerciais/Indice-Acordos.php > Acesso em 27 abr 2007.

A Tabela 1 mostra os acordos internacionais assinados pelo Brasil, após a década de 90 . Estes acordos refletiram no incremento do comércio internacional brasileiro, e a busca constante por novos mercados e a formalização de outros acordos internacionais, tais como 
com a Índia, Marrocos e Israel (MDIC, 2006). Os acordos internacionais proporcionam, aos países signatários, redução dos impostos incidentes sobre os produtos negociados e a uniformização dos procedimentos burocráticos na liberação da importação dos produtos. (MDIC, 2006).

Ainda que possa haver argumentos de que a produção internacional cresceu, é importante comparar a evolução desta produção com o comércio internacional. Para confirmar a hipótese de que o comércio internacional cresceu, independente da produção. $\mathrm{O}$ Gráfico 2, que mostra a variação anual do Produto Interno Bruto (PIB) mundial e as exportações mundiais, nos anos de 2002 a 2004.

Gráfico 2: Variação Anual das Exportações x Variação Anual do PIB 2002-2004

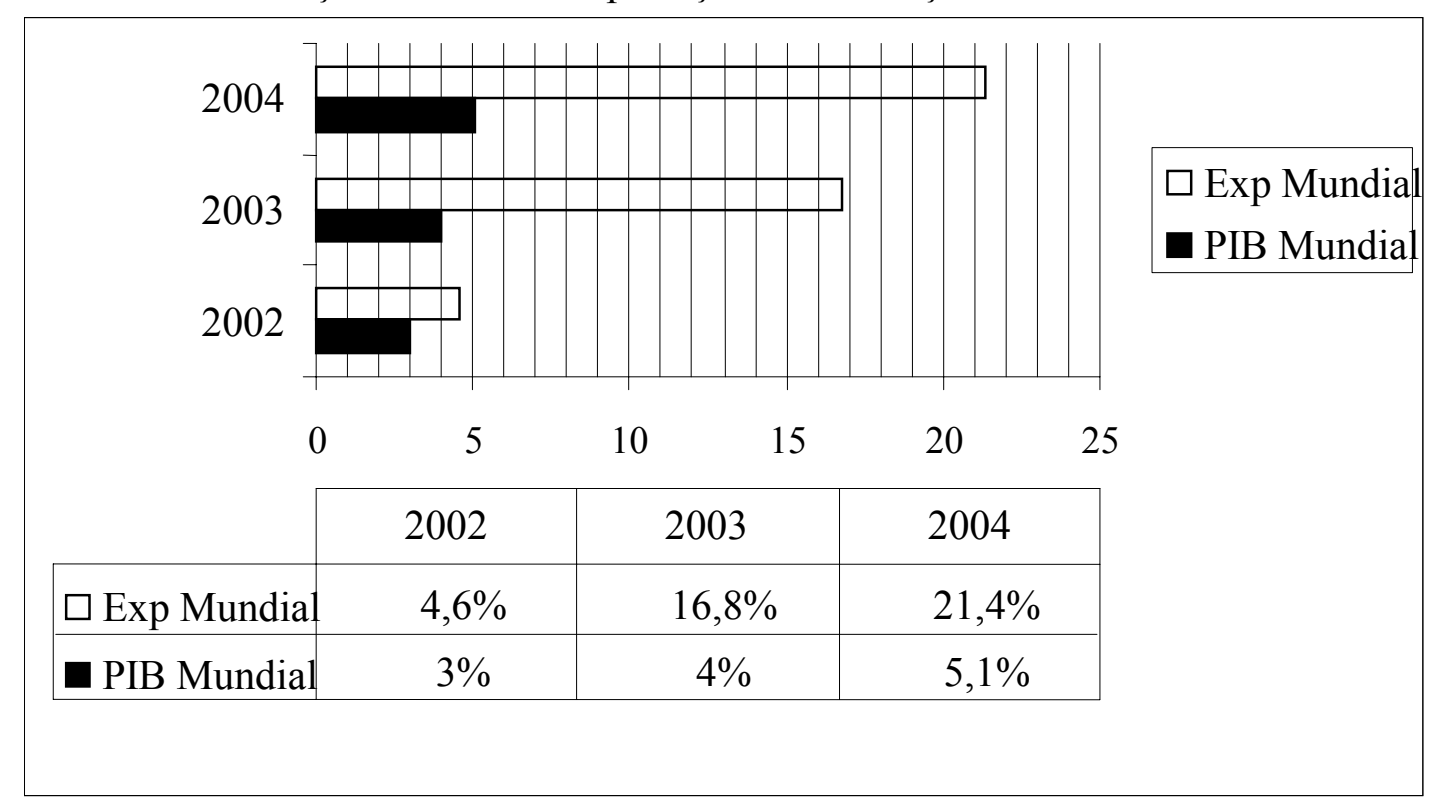

Fonte: Ministério do Desenvolvimento, 2006

O Gráfico 2 mostra que o comércio internacional apresenta um crescimento percentual maior que o crescimento do PIB mundial. Também é possível verificar que no ano de 2004, as exportações mundiais cresceram $21,4 \%$ e a produção mundial $5,1 \%$, ou seja, o volume de 
comércio cresceu quatro vezes mais que a produção mundial, e pode-se confirmar a importância da atividade exportadora. A seguir, será apresentada a participação brasileira no contexto do comércio internacional.

\subsubsection{A Participação do Brasil no Comércio Internacional}

A política comercial brasileira tem um histórico que combina estímulo às exportações com contenção das importações. Por muito tempo, o país conservou o protecionismo como política de preservar a indústria nacional dos grandes competidores. (GUIMARÃES, 2002)

Desde os anos 80, o país vem rompendo a longa tradição da política intervencionista, adotando medidas de liberalização comercial, disseminando informações, por meio dos diversos organismos criados para esse fim, que a participação do Brasil no comércio internacional proporciona recursos ao país com o aumento das divisas e do emprego (GUIMARÃES, 2002).

Ainda que esta política de liberalização comercial tenha produzido uma mudança na mentalidade do país, de que é preciso participar mais ativamente do comércio internacional, pode-se observar que a participação brasileira ainda é pequena (Gráfico 3). 
Gráfico 3: Participação do Brasil nas Exportações Mundiais (1950-2006)

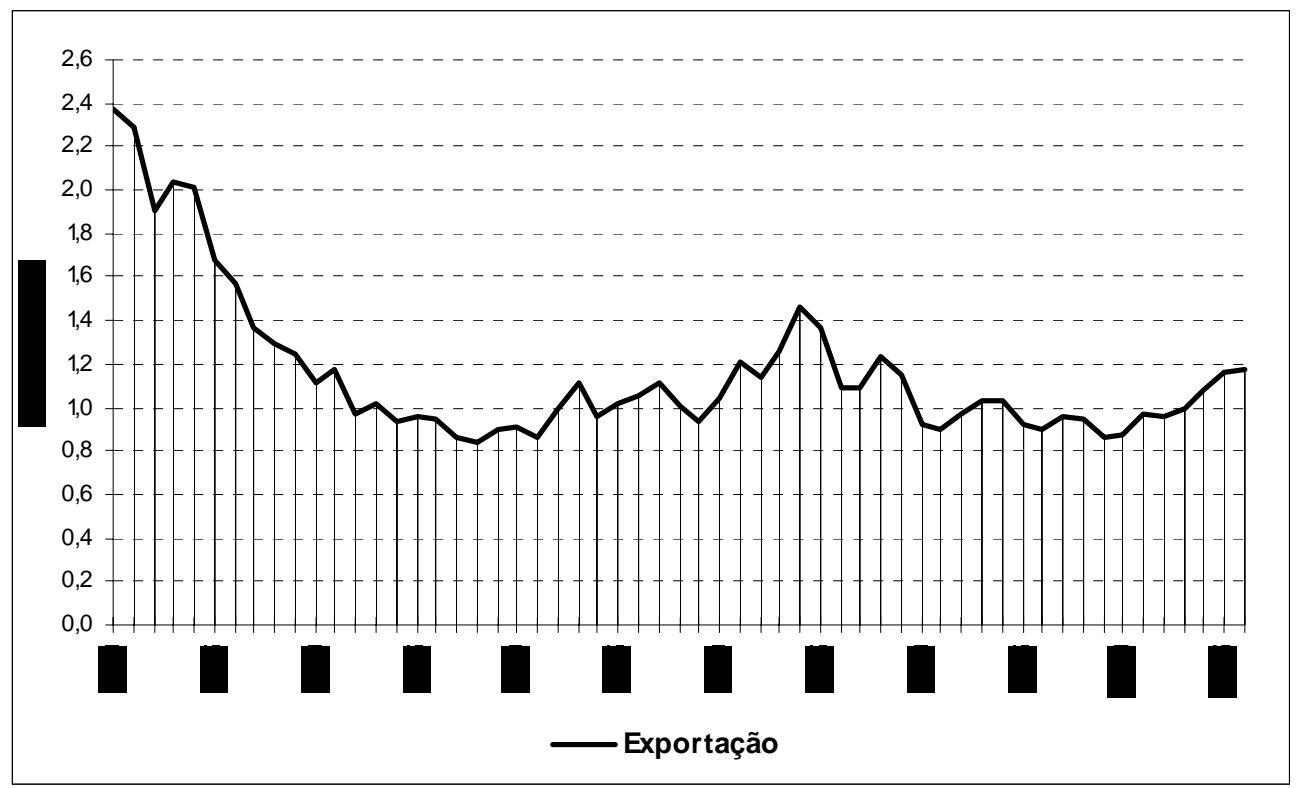

Fonte: Ministério do Desenvolvimento, 2006

O Gráfico 3 mostra que as exportações brasileiras têm uma participação pequena no volume internacional. No ano de 2006, as exportações brasileiras alcançaram 1,2\% do total mundial. Pode-se considerar que o país tem muito para crescer nesta área. Ainda que a política comercial brasileira (PUGA, 2002; GUIMARÃES, 2001) vise, desde os anos 90, incremento nesta participação, há ainda muito que se desenvolver na capacitação técnica e mercadológica para que as empresas atinjam o nível de desempenho de outros países (PUGA, 2000).

Segundo Lima e Carvalho Jr. (2000), o Instituto de Estudos para o Desenvolvimento Industrial (IEDI) realizou um estudo sobre a perda da competitividade das exportações brasileiras no final da década de 90. De acordo com o estudo, os produtos da pauta de exportação do Brasil, pertencentes a setores com demanda crescente no comércio mundial, representavam 52\% das exportações no período 1991/1994 e tiveram uma redução para 36\% no perídio 1994/1998. O estudo concluiu que não basta reduzir custos, mas há necessidade de um novo conjunto de ações coordenadas envolvendo governo e empresas. No que tange às 
empresas, citam os autores, a transição para uma economia aberta, vivida a partir dos anos 90, impôs a necessidade de desenvolvimento de uma cultura exportadora, capacidade de reagir rapidamente frente às oportunidades e de aumentar as vendas no mercado internacional. Lima e Carvalho Jr. (2000) propõem uma série de ações que possibilitam a aceleração da expansão das exportações brasileiras, sintetizadas em:

1- Reduzir o Custo-Brasil

2-Investimentos em Infra-estrutura

3-Eliminar o Viés Antiexportador

4-Desenvolver a cultura exportadora

5-Capacitação Empresarial

As conclusões de Lima e Carvalho Jr. (2000) levantam questões importantes e que podem refletir em um melhor desempenho brasileiro no comércio internacional, mas demanda ações tanto das empresas quanto do governo brasileiro. Para abordar a participação das empresas no cenário internacional, há um breve relato no item a seguir.

\subsubsection{As empresas brasileiras no cenário internacional}

O Gráfico 4 mostra a quantidade de empresas brasileiras exportadoras desde 1990, época em que a política do governo brasileiro se concentrou em incentivar a participação das empresas no cenário internacional. 
Gráfico 4: Empresas Brasileiras Exportadoras 1990-2005

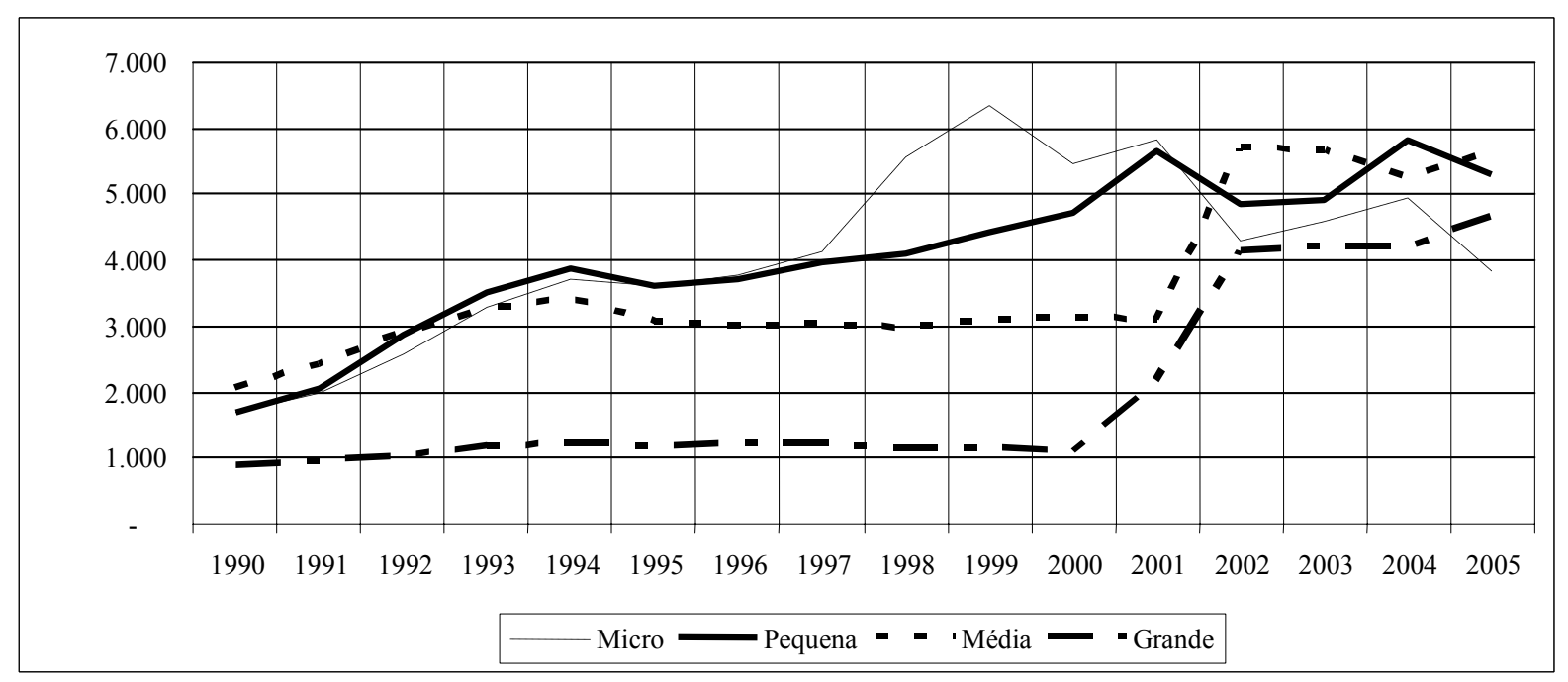

Fonte: Ministério do Desenvolvimento, 2006

Pode-se observar (Gráfico 4) que os esforços governamentais surtiram efeito mais significativo no final da década de 90, com um aumento da quantidade empresas exportadoras.

Gráfico 5 - Volume Exportado por tamanho de empresa 2002-2005

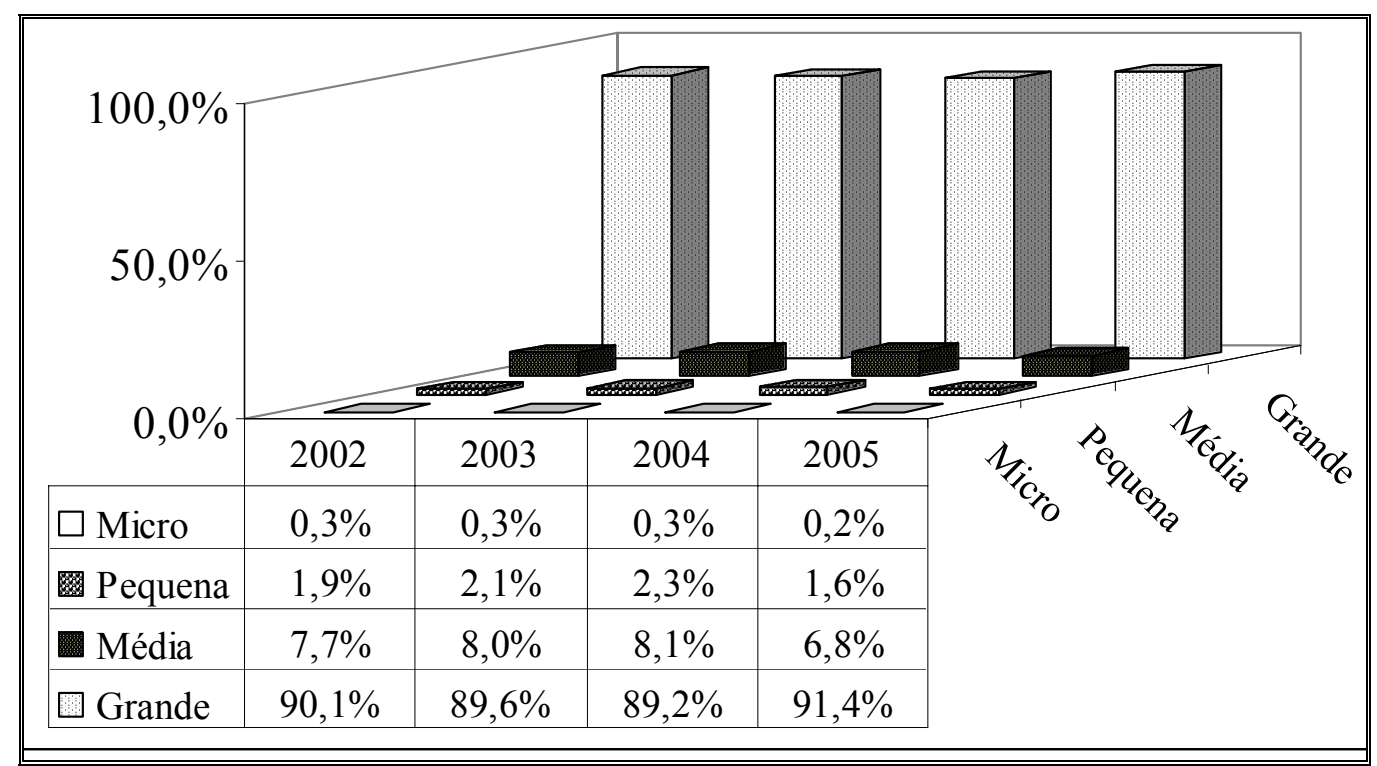


Fonte: Ministério do Desenvolvimento, 2006.

O Gráfico 5 mostra, em percentuais, o volume exportado pelo Brasil, no período 2002 a 2005, discriminado por tamanho de empresa. As grandes empresas têm uma participação significativa neste volume, representando no ano 2005 , 91,4\% do total exportado. A participação das médias empresas apresenta uma queda, passando de 8,1\% em 2004 para $6,8 \%$ em 2005. Também se observa que o volume exportado pelas pequenas empresas decresceu, passando de 2,3\% em 2004 para 1,6\% em 2005.

Lima e Carvalho Júnior (2000) comentam que é necessário contar com as pequenas e médias empresas no universo de exportadores brasileiros. Os autores descrevem os fatores que podem explicar a baixa participação das PME: dificuldades para estabelecer relações duradouras com compradores internacionais, ausência de informações e de visibilidade das oportunidades existentes no mercado internacional.

A empresa, geralmente, não nasce grande, tampouco exportadora e, por ser de pequeno porte, o apoio institucional é fundamental para permitir o alinhamento de suas forças competitivas no mercado doméstico e visando ampliação da participação das empresas brasileiras no mercado internacional (GUIMARÃES, 2002).

O desempenho exportador depende não só de políticas governamentais ou acordos comerciais que possam favorecer o incremento deste comércio, mas demanda conhecimento e informação, bem como capacitação gerencial e técnica das empresas brasileiras para atuação em um mercado cada vez mais competitivo (LIMA e CARVALHO JÚNIOR, 2000; GUIMARÃES, 2002). 
A seguir, apresenta-se um breve relato das pequenas e médias empresas brasileiras no contexto exportador.

\subsubsection{Pequenas e Médias Empresas brasileiras no contexto exportador}

O objetivo deste tópico é apontar as características das PME brasileiras exportadoras e descrever brevemente o desempenho destas empresas no ambiente de negócios internacionais.

O critério utilizado para classificação das empresas por porte, para este estudo é o utilizado pelo Departamento de Planejamento e Comércio Exterior (DEPLA), da Secretaria de Comércio Exterior (SECEX) do Ministério do Desenvolvimento, Indústria e Comércio Exterior (MDIC). Para definir o porte da empresa, o DEPLA/SECEX utiliza metodologia que associa o número de empregados da empresa ao valor exportado que estão detalhados na Tabela 2.

Tabela 2: Classificação das Empresas Exportadoras

\begin{tabular}{|l||c||c||c|c||}
\hline \multicolumn{1}{|c|}{ PORTE } & \multicolumn{2}{c||}{ INDÚSTRIA } & \multicolumn{1}{c||}{ COMÉRCIO E SERVIÇOS } \\
\hline & No.Empregados & Valor & No. Empregados & Valor \\
\hline Micro Empresa & Até 10 & Até US\$ 400 mil & Até 5 & Até US\$ 200 mil \\
\hline $\begin{array}{l}\text { Pequena } \\
\text { Empresa }\end{array}$ & De 11 a 40 & Até US\$ 3,5 milhões & De 6 a 30 & $\begin{array}{c}\text { Até US\$ } 1,5 \\
\text { milhões }\end{array}$ \\
\hline Média Empresa & De 41 a 200 & Até US\$ 20 milhões & De 31 a 80 & Até US\$ 7 milhões \\
\hline Grande Empresa & Acima de 200 & $\begin{array}{c}\text { Acima de US\$ 20 } \\
\text { milhões }\end{array}$ & Acima de 80 & $\begin{array}{c}\text { Acima de US\$ 7 } \\
\text { milhões }\end{array}$ \\
\hline
\end{tabular}

Fonte: Ministério do Desenvolvimento, 2006.

A quantidade de empresas brasileiras participantes no comércio internacional tem crescido a partir do final dos anos noventa. No entanto é necessário comparar a quantidade de empresas exportadoras com o volume exportado. Com esta comparação, cujos dados estão 
mostrados na Tabela 3, pode-se observar o desempenho das PME analisadas no período 2002 a 2005.

Tabela 3: Volume de Exportações por tamanho de empresa 2002 a 2005

\begin{tabular}{|l|r|r||r|r||}
\hline US\$ mil & \multicolumn{1}{|c|}{$\mathbf{2 0 0 2}$} & \multicolumn{1}{c|}{$\mathbf{2 0 0 3}$} & \multicolumn{1}{|c|}{$\mathbf{2 0 0 4}$} & \multicolumn{1}{c|}{$\mathbf{2 0 0 5}$} \\
\cline { 2 - 5 } Micro & 168.005 & 220.352 & 302.139 & 238.732 \\
\hline Pequena & 1.165 .763 & 1.515 .655 & 2.252 .835 & 1.911 .926 \\
\hline Média & 4.655 .163 & 5.844 .373 & 7.809 .633 & 7.995 .319 \\
\hline Grande & 54.313 .991 & 65.400 .551 & 85.880 .361 & 107.945 .512 \\
\hline Total & $\mathbf{6 0 . 3 0 2 . 9 2 2}$ & $\mathbf{7 2 . 9 8 0 . 9 3 1}$ & $\mathbf{9 6 . 2 4 4 . 9 6 8}$ & $\mathbf{1 1 8 . 0 9 1 . 4 8 9}$ \\
\hline
\end{tabular}

A Tabela 3 mostra que o volume exportado pelas grandes empresas é muito maior que as demais empresas. Para melhor comparação, a Tabela 4 mostra, em percentuais, a quantidade de empresas exportadoras e o volume exportado por porte de empresa.

Tabela 4: No. de empresas x Volume Exportado 2002 a 2005

\begin{tabular}{|c|c|c|c|c|c|c|c|c|}
\hline & \multicolumn{2}{|c|}{2002} & \multicolumn{2}{|c|}{2003} & \multicolumn{2}{|c|}{2004} & \multicolumn{2}{|c|}{2005} \\
\hline & $\begin{array}{c}\text { No. } \\
\text { empresas } \\
\end{array}$ & Exportações & $\begin{array}{c}\text { No. } \\
\text { empresas } \\
\end{array}$ & Exportações & \begin{tabular}{|c|} 
No. \\
empresas
\end{tabular} & Exportações & \begin{tabular}{|c|} 
No \\
empresas \\
\end{tabular} & Exportações \\
\hline Micro & $22,67 \%$ & $0,28 \%$ & $23,68 \%$ & $0,30 \%$ & $24,35 \%$ & $0,31 \%$ & $19,67 \%$ & $0,20 \%$ \\
\hline Pequena & $25,49 \%$ & $1,93 \%$ & $25,35 \%$ & $2,08 \%$ & $28,65 \%$ & $2,34 \%$ & $27,36 \%$ & $1,62 \%$ \\
\hline Média & $30,02 \%$ & $7,72 \%$ & $29,21 \%$ & $8,01 \%$ & $25,81 \%$ & $8,11 \%$ & $29,04 \%$ & $6,77 \%$ \\
\hline Grande & $21,82 \%$ & $90,07 \%$ & $21,76 \%$ & $89,61 \%$ & $21,18 \%$ & $89,23 \%$ & $23,93 \%$ & $91,41 \%$ \\
\hline & $100,00 \%$ & $100,00 \%$ & $100,00 \%$ & $100,00 \%$ & $100,00 \%$ & $100,00 \%$ & $100,00 \%$ & $100,00 \%$ \\
\hline
\end{tabular}

A Tabela 4 compara os dados das tabelas anteriores (Tabelas 2 e 3), de forma a explorar o desempenho exportador das PME em relação ao volume exportadora nos anos 2002 a 2005. Observa-se que a quantidade de médias empresas exportadoras, em percentuais, é maior que o 
percentual das grandes empresas, porém, o volume exportado é muito menor, não atingindo $10 \%$ do volume exportado por grandes empresas.

Os dados obtidos também permitem observar que, em relação às pequenas empresas, a quantidade de empresas aumentou de 25,49\% em 2002 para 27,36\% em 2005. No entanto, a participação no volume exportado do país decresceu de 1,93\% em 2002 para 1,62\% em 2005. Observando os dados das médias empresas, a quantidade de empresas exportadoras, diminuiu de 30,02\% em 2002, chegando a 25,81\% em 2004 e recuperando a participação em 29,04\% em 2005. Em relação ao volume exportado, a participação também é pequena nos anos observados, com uma queda na participação de 7,72\% em 2004, chegando a 8,11\% em 2004, mas decrescendo para $6,77 \%$ em 2005.

O governo brasileiro atua, desde os anos 2000, como grande incentivador do processo de crescimento da participação das PME no volume exportado. Um exemplo da atuação é a criação de programas de incentivo à exportação, com a redução nos trâmites operacionais, tais como o "Exporta Fácil", operacionalizado pela Empresa Brasileira de Correios e Telégrafos, para pequenos volumes, que não excedam 30kilos e valor máximo até US 20.000,00, definidos pela Secretaria da Receita Federal desde 2006 , conhecida como Remessa Postal Internacional.

Os resultados apresentados nesta Seção despertam indagações sobre a pequena participação das empresas brasileiras, notadamente as PME, no comércio internacional, bem como sobre as alternativas para o incremento das exportações brasileiras, que possam representar o desenvolvimento de ações conjuntas empresas x governo neste cenário.

\footnotetext{
${ }^{1}$ Instrução Normativa SRF 611 de 18/01/06, disponível em <www.receita.fazenda.gov.br/legislação/Ins/2006/In6112006.htm>
} 


\subsection{Formulação do Problema}

Os itens anteriores apresentaram informações do comércio internacional, a participação brasileira neste contexto, complementando com alguns dados das Pequenas e Médias empresas brasileiras. O Banco Nacional de Desenvolvimento Econômico e Social (BNDES), publicou, em 2002, estudos baseados em pesquisas de campo com empresas brasileiras exportadoras, buscando respostas para o desempenho exportador brasileiro. Os resultados apresentados por Markwald e Puga (in: BNDES, 2002, Texto 4), obtidos em pesquisa de campo com 243 empresas industriais exportadoras, mostram as maiores dificuldades associadas à atividade exportadora, que estão descritas na Tabela 5.

Tabela 5. Maiores dificuldades associadas à atividade exportadora (\%)

\begin{tabular}{l|c|c|c}
\hline \hline Dificuldades & $1^{\circ}$.Lugar & $2^{\circ}$.Lugar & $3^{\circ}$.Lugar \\
\hline \hline Obter informações comerciais (sobre mercados, concorrência, etc.) & 23,5 & 15,2 & 22,2 \\
$\begin{array}{l}\text { Lidar com procedimentos burocráticos e administrativos ligados à } \\
\text { exportação }\end{array}$ & 43,6 & 20,6 & 12,3 \\
$\begin{array}{l}\text { Adaptar-se internamente para atender a demanda externa: produtos e } \\
\text { processos produtivos }\end{array}$ & 16,5 & 18,9 & 21,0 \\
$\begin{array}{l}\text { Obter informações sobre regras que afetam acesso a mercados } \\
\text { externos: normas técnicas, barreiras comerciais, etc. }\end{array}$ & 12,8 & 36,2 & 29,6 \\
Não Respondeu & 3,7 & 9,1 & 14,8 \\
\hline \hline Total & 100 & 100 & 100 \\
\hline \hline
\end{tabular}

Fonte: Markwald e Puga, 2002

Os dados obtidos na pesquisa (Tabela 5) mostram que as empresas da amostra citam o acesso a informações comercias, regras de mercado e os procedimentos burocráticos e administrativos como as maiores dificuldades associadas à atividade exportadora. 
Outro estudo foi realizado pelo Serviço de Apoio às Micro e Pequenas Empresas (SEBRAE) em agosto de 1998, no qual, a dificuldade de obter informações também é verificada com micro e pequenas empresas (Tabela 6). Nesta pesquisa, os dados foram comparados com empresas não exportadoras.

Tabela 6: Fatores mais importantes para o sucesso de uma empresa

\begin{tabular}{l||c||c}
\hline \hline Fatores & Exportadoras & Não Exportadoras \\
\hline \hline Boa organização administrativa & $54,4 \%$ & $53,0 \%$ \\
Conhecimento do mercado onde atua & $47,0 \%$ & $40,2 \%$ \\
Boa administração financeira & $38,0 \%$ & $44,4 \%$ \\
Aproveitamento das oportunidades de negócio & $35,4 \%$ & $37,1 \%$ \\
Conhecimento da conjuntura Econômica & $22,5 \%$ & $20,1 \%$ \\
\hline \hline
\end{tabular}

Fonte: Sebrae, 1998. (A questão admitia mais de uma resposta)

Os resultados da Tabela 6 reforçam o reconhecimento da necessidade de informação para o sucesso das empresas no mercado internacional, tanto por empresas exportadoras quanto por não exportadoras. A pesquisa mostra que 47,0\% das empresas exportadoras citaram o conhecimento do mercado onde atua como um dos fatores mais importantes para o sucesso na atividade. Pode-se observar que 40,2\% das empresas não exportadoras também citaram o conhecimento do mercado onde atua como um dos fatores mais importantes. Ainda que o percentual das variáveis que envolvem conhecimento não seja o principal fator citado na pesquisa, pode ser considerado relevante e pode ser mais explorado.

Os resultados das pesquisas realizadas pelo BNDES (2002) e SEBRAE (1998), citados anteriormente, podem suscitar questionamentos quanto à experiência exportadora. $\mathrm{Na}$ publicação do BNDES (2002), Ferraz Filho e Ribeiro (in: BNDES, Texto 13), apresentam no relatório o grau de dificuldade encontrado em relação aos maiores entraves enfrentados pelas empresas exportadoras. Nesta pesquisa, foi solicitada às empresas a atribuição de nota de 1 
(nenhuma dificuldade) a 5 (muita dificuldade) com o objetivo de avaliar os maiores entraves enfrentados nas fases de entrada, consolidação e expansão de suas atividades no mercado externo (FERRAZ FILHO \& RIBEIRO, 2002), cujos resultados são apresentados na Tabela 7

Tabela 7: Grau de Dificuldade em relação aos fatores exigidos pela experiência exportadora*

\begin{tabular}{|c|c|c|c|c|c|c|c|c|c|}
\hline & \multicolumn{3}{|c|}{ ENTRADA } & \multicolumn{3}{|c|}{ CONSOLIDAÇÃO } & \multicolumn{3}{|c|}{ EXPANSÃO } \\
\hline & $\stackrel{\text { In }}{\text { In }}$ & $\begin{array}{l}\stackrel{\Xi}{\Xi} \\
: \\
\Sigma \\
\end{array}$ & 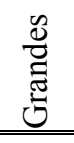 & $\sum_{\Sigma}^{n}$ &  & 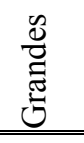 & $\stackrel{n}{\tilde{N}}$ &  & 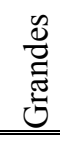 \\
\hline Informação sobre mercados, clientes e concorrência. & 3,0 & 2,5 & 2,7 & 2,5 & 2,2 & 2,2 & 2,4 & 2,2 & 2,0 \\
\hline Recursos Gerenciais & 2,7 & 2,3 & 2,4 & 2,5 & 2,1 & 2,0 & 2,3 & 2,2 & 1,9 \\
\hline Desenvolver Novos Produtos no ritmo do mercado & 2,2 & 2,2 & 2,3 & 2,0 & 2,0 & 2,0 & 2,0 & 1,8 & 1,8 \\
\hline Atraso Tecnológico da empresa & 2,1 & 2,1 & 2,2 & 2,0 & 2,0 & 2,0 & 1,9 & 1,9 & 1,6 \\
\hline Normas exigidas pelos importadores & 2,1 & 2,1 & 2.1 & 1,9 & 1,9 & 1,9 & 1,9 & 1,8 & 1,9 \\
\hline Escala insuficiente de produção & 2,1 & 2,0 & 2,1 & 1,9 & 1,9 & 1,8 & 1,9 & 2,0 & 1,9 \\
\hline Prioridade à atividade exportadora & 2,0 & 2,0 & 2,0 & 1,9 & 1,8 & 1,8 & 1,9 & 2,0 & 1,8 \\
\hline Falta de Autonomia por pertencer a grupo empresarial & 1,5 & 1,6 & 1,9 & 1,5 & 1,5 & 1,8 & 1,4 & 1,5 & 1,8 \\
\hline
\end{tabular}

Fonte: Ferraz Filho \& Ribeiro, 2002.

*Grau Médio de Dificuldade: Muita Dificuldade $(5,0)$ e Nenhuma Dificuldade $(1,0)$.

A Tabela 7 mostra que a dificuldade relativa à informação sobre mercados, clientes e concorrência é o fator mais apontado pelas empresas, independentemente do tamanho da empresa e da experiência exportadora.

$\mathrm{Na}$ fase de entrada, as empresas citam como maior dificuldade a obtenção de informações sobre mercados, clientes e concorrência, no entanto esta dificuldade, ainda que em menor proporção se mantenha nas fases de consolidação e expansão. Além disso, a dificuldade é observada também nas grandes empresas. 
Na publicação do BNDES (2002), Ferraz Filho e Ribeiro (in: BNDES, 2002, Texto 13) apresentam, no relatório de pesquisa de campo com 460 empresas entrevistadas, as maiores dificuldades associadas à atividade exportadora, detalhadas por tamanho da empresa (Tabela 8) e por freqüência exportadora (Tabela 9).

Tabela 8 Dificuldades associadas à atividade exportadora por tamanho de empresa $(\%)^{\natural}$

\begin{tabular}{lcccc}
\hline \hline Dificuldades & Total & MPEs & Médias & Grandes \\
\hline \hline Informações sobre regras para acesso a mercados & 79,0 & 80,6 & 77,5 & 77,2 \\
Procedimentos burocráticos e administrativos & 76,3 & 72,1 & 78,2 & 82,5 \\
Informações comerciais (mercados, concorrência, etc.) & 63,7 & 70,3 & 57,6 & 58,8 \\
Requisitos Exigidos (produtos, processos e etc.) & 54,5 & 53,3 & 52,3 & 60,8 \\
\hline \hline
\end{tabular}

Fonte: Ferraz Filho e Ribeiro, 2002.

Tabela 9: Dificuldades associadas à atividade exportadora por freqüência exportadora

\begin{tabular}{lccccc}
\hline \hline & Total & Iniciante & Esporádica & Assídua & Permanente \\
\hline \hline Informações sobre regras para acesso a mercados & 79,0 & 79,2 & 84,6 & 77,7 & 78,6 \\
Procedimentos burocráticos e administrativos & 76,3 & 73,3 & 84,6 & 76,6 & 76,5 \\
Informações comerciais (mercados, concorrência, etc.) & 63,7 & 63,8 & 73,0 & 65,5 & 60,9 \\
Requisitos Exigidos (produtos, processos e etc.) & 54,5 & 52,5 & 49,9 & 53,3 & 56,4 \\
\hline
\end{tabular}

Fonte: Ferraz Filho e Ribeiro, 2002.

A ordem de importância das dificuldades associadas à atividade exportadora se repete nas Tabelas 8 e 9, quando analisadas por grupo de empresas discriminadas por tamanho e por freqüência exportadora. A necessidade de informação aparece com maior importância tanto nas empresas de menor porte quanto no grupo das iniciantes em operações comerciais internacionais, citada por $79 \%$ das empresas pesquisadas.

\footnotetext{
${ }^{2}$ Proporção de empresas que citaram como uma das três mais importantes.

${ }^{3}$ Freqüência Exportadora - definida com base nas exportações do período 1994-2000, seguindo os critérios:

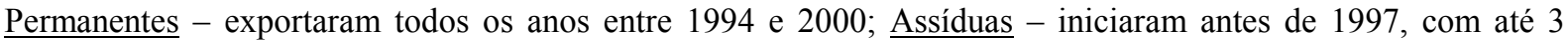
interrupções; Esporádicas - iniciaram antes de 1997, com 4 ou 5 interrupções; e Iniciantes - iniciaram a partir de 1997, de forma continuada ou não.
} 
Com base nos resultados das pesquisas citadas, entende-se que a informação é um fator importante, que merece ser mais explorado, avaliando suas características e identificando a demanda de informação ao longo do processo de inserção internacional e as fontes utilizadas pelas empresas. Mesmo que parte dos esforços das empresas esteja focada nos procedimentos operacionais, a consolidação na atividade exportadora pode desencadear necessidade maior de informação (VEIGA, 2002) como suporte ao processo decisório.

Segundo Keegan (2005) o executivo precisa saber onde obter as informações, pois o esforço maior é o gerenciamento de um sistema de coleta de informações, e é neste foco que esta pesquisa se propõe a desenvolver com a pergunta de pesquisa.

Quais são as informações utilizadas por empresas exportadoras para tomar decisões acerca de sua atuação em mercados externos?

\subsection{Objetivos da Pesquisa}

\section{Objetivo Geral}

Identificar as informações consideradas importantes, utilizadas pelas empresas exportadoras, em sua atuação no mercado externo.

\section{Objetivos Específicos:}

a) Identificar as informações sobre mercados internacionais utilizadas pelas empresas atuar no mercado internacional. 
b) Avaliar a freqüência de uso dos diversos tipos de informação.

c) Investigar as fontes de informação utilizadas pelas empresas exportadoras.

d) Identificar os perfis de ação das empresas na exportação.

e) Avaliar as relações entre as variáveis levantadas na pesquisa de campo.

\subsection{Justificativa, Importância e Contribuições do Estudo.}

O fator que mais motivou este estudo é a indicação, nas pesquisas, da informação como uma das dificuldades para atuação no mercado internacional. Acrescenta-se a esta motivação, o incremento de ações governamentais para incentivar a participação brasileira no mercado internacional, bem como a constatação de que as pequenas e médias empresas brasileiras têm baixa participação neste cenário.

Segundo Kuazaki (1999), para atuar no mercado internacional, é necessário conhecer as principais características dos mercados por meio de estudos e planejamento que envolvam decisões do que exportar, para onde e como, e exige das empresas um certo grau de conhecimento das variáveis do ambiente para o estabelecimento de estratégias de atuação.

Os estudos realizados no Brasil, que envolvem empresas exportadoras, podem ser divididos em dois grupos de interesses: órgãos do governo e pesquisas acadêmicas.

1) Os estudos do governo brasileiro buscam investigar o desempenho exportador, explorar e quantificar volume de negócios, política de exportação e barreiras enfrentadas pelos exportadores brasileiros, e que são realizados por órgãos oficiais como o BNDES 
(PUGA, 2000; VEIGA, 2002; MARKWALD e PUGA, 2002; GUIMARÃES, 2002) e SEBRAE (1998 e 2005).

2) Os estudos acadêmicos buscam investigar orientação para o mercado externo (MARCERA \& URDAN, 2003), dimensionar estratégias gerenciais para exportação (CABRAL \& SILVA JR, 2004), capacidade de exportação e inovação (ARBIX et al., 2005), percepção de barreiras (SILVA \& ROCHA, 2001), envolvimento e desempenho exportador (MACHADO, 2005).

O ambiente de negócios internacionais proporciona um universo de investigações e este estudo busca contribuir com a investigação das informações sobre mercados internacionais que possam ser aplicadas à atuação bem sucedida das empresas exportadoras. O mercado internacional exige capacitação empresarial e a pesquisa acadêmica pode contribuir com esta capacitação, à medida que investiga e coordena os esforços para projetar as empresas no cenário internacional.

\subsection{Delimitações do Estudo}

Esta pesquisa busca investigar as informações utilizadas pelas empresas exportadoras na tomada de decisão na atuação no mercado internacional, e está delimitada em dois pontos principais:

$1^{\text {o. }}$ Empresas exportadoras situadas em Ribeirão Preto e região.

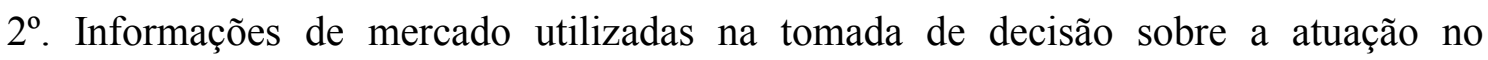
mercado internacional, que serão detalhadas na revisão da literatura. 
Os relatórios do governo brasileiro, divulgados pelo MDIC (2006) também não individualizam as informações por tamanho de empresa, limitando-se a divulgar o desempenho das exportações brasileiras agrupados por regiões e por volume exportado. Além disso, a metodologia utilizada pelo MDIC para a pesquisa e divulgação do resultado é em função do volume exportado, independente do tamanho da empresa. Em função desta limitação, o estudo está delimitado por empresas situadas na região de Ribeirão Preto, cujos qualificadores estão apresentados no Capítulo 4 que apresenta o resultado do estudo empírico. A metodologia de seleção das empresas está descrito no Capítulo 3 - Metodologia do Estudo.

Esta pesquisa está focada nos objetivos gerais e específicos descritos anteriormente, e não é intenção esgotar o tema, mas, principalmente, depois da investigação, gerar hipóteses relacionadas aos objetivos que contribuam para futuras pesquisas. 


\section{Revisão da Literatura}

\subsection{As Estratégias de Inserção no Mercado Internacional}

A inserção internacional é parte integrante do desenvolvimento das nações, pois trata das relações de compra, venda e troca de mercadorias e serviços que irão gerar fluxo de capitais entre as nações. As bases conceituais do comércio internacional surgiram entre o século XVI e metade do século XVIII com estudos e teorias desenvolvidas em dimensões macroeconômicas. (DIAS et al. 2004; SOARES, 2004; AMARAL, 2004).

As teorias econômicas mais influentes sobre o comércio internacional podem ser visualizadas no Quadro 1.

Quadro 1: Teorias do Comércio Internacional

\begin{tabular}{|c|c|c|}
\hline Teorias & Fundamentação & Autor \\
\hline $\begin{array}{l}\text { Teoria das Vantagens } \\
\text { Absolutas }\end{array}$ & $\begin{array}{l}\text { O fundamento do comércio internacional é a divisão internacional } \\
\text { do trabalho, ou a especialização de cada país em uma atividade } \\
\text { econômica produz vantagens absolutas medidas em horas-trabalho. }\end{array}$ & $\begin{array}{l}\text { Adam } \\
\text { Smith, } \\
(1776)\end{array}$ \\
\hline $\begin{array}{l}\text { Teoria das Vantagens } \\
\text { Comparativas }\end{array}$ & $\begin{array}{l}\text { A eficiência relativa é considerada na dotação e eficiência dos } \\
\text { fatores de produção analisada pelo custo de oportunidade quando } \\
\text { um país deixa de produzir quando não tem recursos para a } \\
\text { produção. }\end{array}$ & $\begin{array}{l}\text { David } \\
\text { Ricardo, } \\
(1817)\end{array}$ \\
\hline $\begin{array}{l}\text { Dotação Relativa dos } \\
\text { Fatores }\end{array}$ & $\begin{array}{l}\text { Analisa as vantagens do comércio internacional em relação a } \\
\text { capital e trabalho. Cada país tem disponibilidades diferentes em } \\
\text { cada fator e devem se especializar no fator que tem mais vantagem. }\end{array}$ & $\begin{array}{l}\text { Hecksher } \\
(1933) \\
\text { Ohlin } \\
(1950)\end{array}$ \\
\hline $\begin{array}{l}\text { Teoria da Demanda } \\
\text { Doméstica }\end{array}$ & $\begin{array}{l}\text { A demanda de um país aumenta com o crescimento da renda per } \\
\text { capita e países semelhantes possuem um volume de comércio } \\
\text { maior. }\end{array}$ & $\begin{array}{l}\text { Linder } \\
(1961)\end{array}$ \\
\hline $\begin{array}{l}\text { Teoria do Ciclo do } \\
\text { Produto }\end{array}$ & $\begin{array}{l}\text { O país que tem vantagem comparativa na produção e exportação de } \\
\text { um produto inovador altera seu fluxo de comércio na medida em } \\
\text { que a tecnologia de produção de mercadoria amadurece. }\end{array}$ & $\begin{array}{l}\text { Vernon } \\
(1966)\end{array}$ \\
\hline $\begin{array}{l}\text { Teoria do Comércio e } \\
\text { Mercados Imperfeitos }\end{array}$ & $\begin{array}{l}\text { A mudança no fluxo de comércio é sustentada nas imperfeições do } \\
\text { comércio de produtos e dos mercados }\end{array}$ & $\begin{array}{l}\text { Krugman } \\
(1985)\end{array}$ \\
\hline $\begin{array}{l}\text { Vantagem Competitiva } \\
\text { das Nações }\end{array}$ & $\begin{array}{l}\text { A competitividade das nações depende da capacidade de inovação } \\
\text { e reação das indústrias, que ganham vantagem competitiva por } \\
\text { causa das mudanças, beneficiando-se nos mercado doméstico. }\end{array}$ & $\begin{array}{l}\text { Porter } \\
(1990)\end{array}$ \\
\hline
\end{tabular}

Fonte: Leonidou \& Katsikeas, 1996 e Soares, 2004 
Os estudos listados no Quadro 1 contribuíram para o entendimento do comércio, com base na disponibilidade dos fatores de produção (capital e trabalho) e, sem dúvida proporcionaram um conceito de que a participação no comércio internacional é vantajosa para os países. No entanto, a limitação das teorias econômicas evidenciou a necessidade de estudos direcionados às empresas, visto que não abordaram o comportamento das empresas que atuam neste cenário, comprando, vendendo e promovendo seus produtos e, principalmente buscando estratégias para atuação no mercado internacional.

Em função das limitações das teorias econômicas, que explicam parcialmente o comportamento exportador das empresas, outros pesquisadores desenvolveram estudos mais aprofundados, criando modelos que conceituaram a iniciativa individual das empresas, buscando o entendimento da participação no mercado internacional, (LEONIDOU \& KATSIKEAS, 1995) e esse é o foco da revisão da literatura nos parágrafos que se seguem.

\subsubsection{O modelo Uppsala}

Do ponto de vista mercadológico, o processo de internacionalização foi estudado e desenvolvido por pesquisadores da Universidade de Uppsala (Escola Nórdica de Negócios), mencionado como U-Model (Uppsala Model), Johanson e Wiedersheim-Paul (1975) e Johanson e Vahlne (1977).

O modelo de Uppsala é, inicialmente, associado à pesquisa conduzida por Johanson \& Wiedersheim-Paul (1975) com quatro empresas industriais suecas - Sandvik, Atlas Copto, Facit e Volvo (JOHANSON \& VAHLNE, 1977) que apresentavam algumas características comuns no processo de expansão internacional. Os autores observaram que as empresas se 
desenvolveram em determinado mercado internacional investindo recursos seqüencialmente e o montante investido dependia do grau de conhecimento da empresa a respeito desse mercado. Em outras palavras: quanto maior o grau de conhecimento da empresa sobre o mercado, maior a tendência em investir recursos nesse mercado.

A segunda característica observada por Johanson \& Wiedersheim-Paul (1975) é a distância psíquica, definida como as diferenças percebidas entre valores, práticas gerenciais e educação de dois países. Em processos de expansão internacional, estas características são consideradas importantes pelos autores, pois podem restringir a disposição das empresas em investir em países considerados culturalmente distintos, existindo evidências de que a empresa começa o seu processo de internacionalização em países considerados culturalmente próximos. Minervini (2005) e Kuazaqui (1999) também abordam a proximidade cultural como fator relevante para o início das atividades de uma empresa no mercado internacional.

Em 1977, as pesquisas desenvolvidas por Johanson \& Vahlne (1977) originaram o modelo de Uppsala. Este modelo é baseado em três pressupostos:

- a falta de conhecimento é o maior obstáculo em processos de internacionalização;

- o conhecimento necessário à internacionalização é principalmente adquirido por meio das operações atuais da empresa em determinado mercado-alvo;

- a empresa internacionaliza suas operações investindo recursos de maneira gradual.

Baseados nesses pressupostos, Johanson \& Vahlne (1977) introduzem dois conceitos para explicar o modelo: conhecimento e comprometimento. Conhecimento refere-se ao conhecimento do mercado-alvo, enquanto comprometimento diz respeito ao montante de recursos investidos em determinado mercado internacional e ao grau de especificidade desses 
recursos, ou seja, à possibilidade de utilizar esses recursos em outros mercados sem que ocorra a desvalorização deles.

Conhecimento e comprometimento são entendidos como os estados do modelo. Johanson \& Vahlne (1977) sugerem que a dinâmica entre conhecimento e comprometimento pode ser ilustrada pelas seguintes relações (Figura 1)

$\checkmark$ Maior investimento da empresa em determinado mercado internacional, implica em maior conhecimento sobre esse mercado;

$\checkmark$ Maior o grau de conhecimento da empresa sobre esse mercado, implica em maior grau de aptidão para efetuar novos investimentos;

$\checkmark$ Maior o grau de aptidão da empresa, maior a probabilidade de que os investimentos sejam realizados; e assim sucessivamente.

Figura 1: Dinâmica do Modelo Uppsala

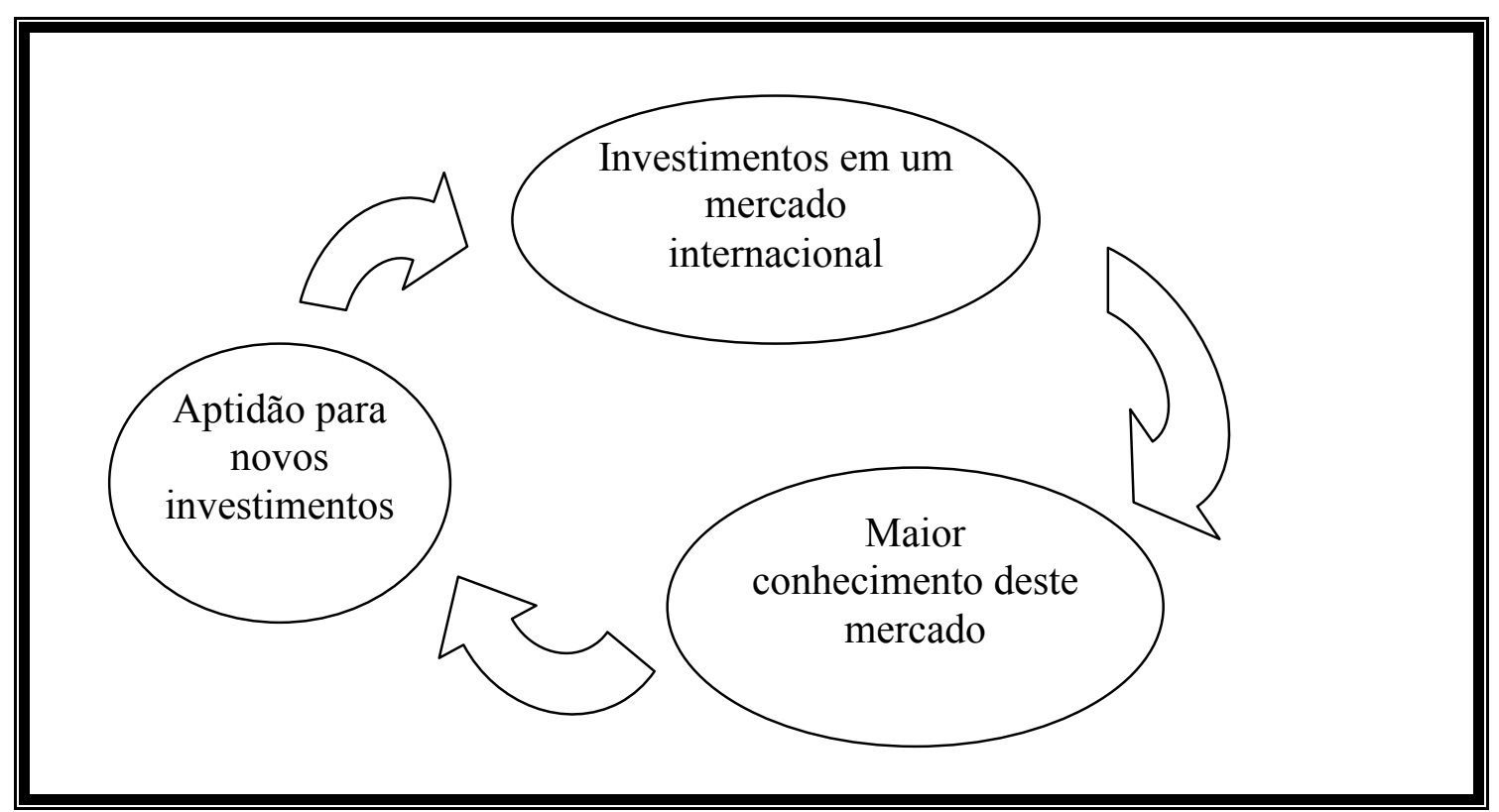

Fonte: Elaborada pela autora a partir de Johanson \& Vahlne, 1977

O modelo Uppsala, ou modelo dinâmico de aprendizagem enfoca o processo de inserção internacional do ponto de vista organizacional e direcionando o uso do conhecimento 
sobre mercados internacionais para o sucesso de uma empresa (HEMAIS et al., 2004; BRIDGEWATER et al., 2002), aumentando seu comprometimento de forma gradual em estágios, iniciando pela exportação indireta até atingir o nível mais complexo que é o Investimento Estrangeiro Direto, caracterizado pela instalação da empresa em outro país (LEONIDOU \& KATSIKEAS, 1996).

O modelo Uppsala, segundo Leonidou \& Katsikeas (1996), evidencia o papel crítico da aquisição da informação, a qual está diretamente ligada à progressão incremental da empresa ao longo do trajeto da internacionalização, procurando reduzir os níveis de incerteza a respeito das operações nos mercados externos.

As etapas do processo de inserção internacional estão apresentadas no item a seguir.

\subsubsection{O processo de inserção internacional}

É importante observar que a inserção internacional é um processo, no qual as empresas se preparam para atuar no mercado internacional e pode ser estudada sob várias óticas, que dependem do nível de envolvimento das empresas no processo exportador. Palácios e Sousa (2005) ilustram essa abordagem do processo de internacionalização, com um modelo em que

à medida que a empresa adquire experiência em operações internacionais, maior será a complexidade de suas operações (Figura 2).

A Figura 2 mostra que o primeiro estágio da inserção internacional é a exportação, seja direta ou indireta. A experiência com o mercado externo mobiliza fatores internos para que a 
empresa prossiga no processo até atingir o ponto mais complexo. A complexidade vai exigir da empresa o desenvolvimento de competências para que esta estratégia seja bem sucedida.

Figura 2: Etapas da Inserção Internacional de Empresas

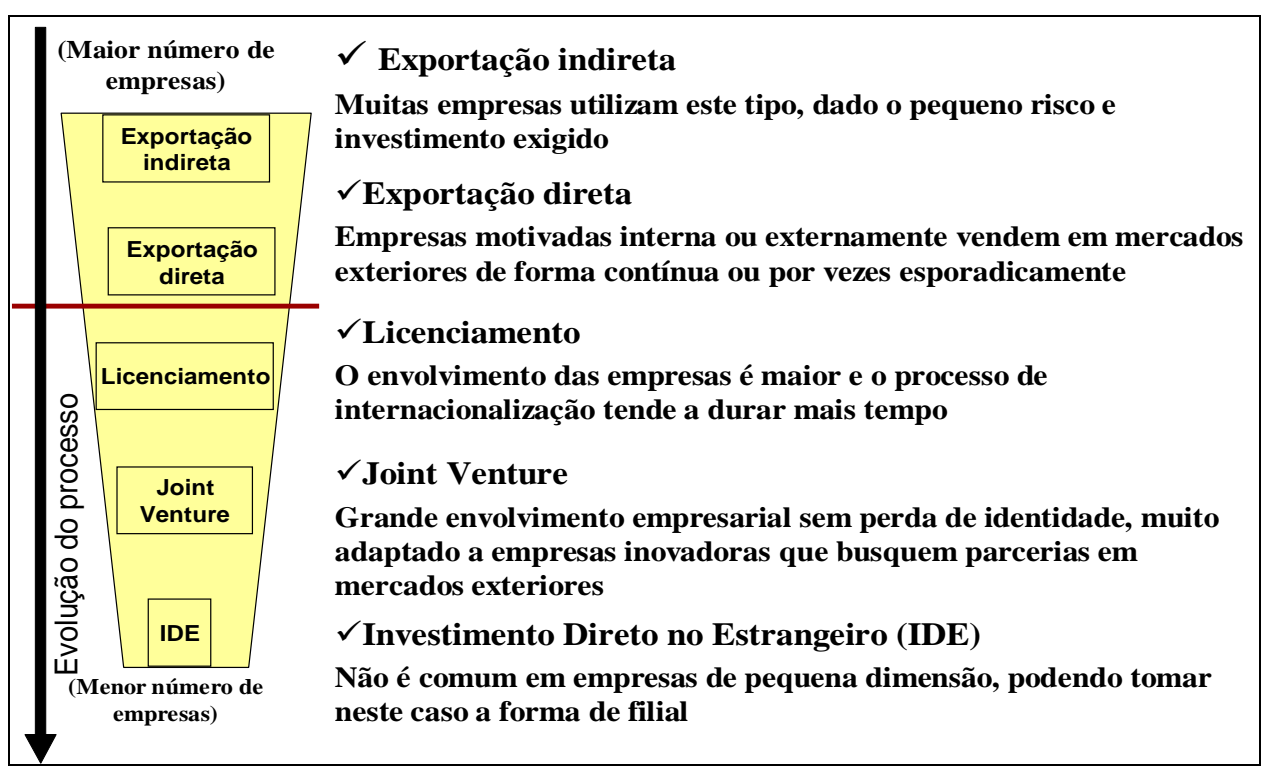

Fonte: Palácios \& Sousa (2004)

A exportação é a saída de mercadoria do país que gera a entrada de capitais, e pode ser feita em dois estágios: Indireta - utilizando intermediários que se encarregam da venda do produto e Direta - quando o próprio fabricante se encarrega com a venda ao exterior. O segundo estágio - Exportação direta (Figura 2) pode-se configurar em características diferentes entre as empresas, pois dependem do tipo de produto, bem como o mercado que se quer atingir.

A exportação foi estudada por autores que buscaram identificar os estágios em que a empresa se desenvolve no processo exportador. Bilkey e Tesar (1977), Cavusgil (1980), Reid (1981) Cinzioka (1982), Barret \& Wilkinson (1986), conceituam o desenvolvimento do processo exportador na perspectiva da empresa, estabelecendo estágios de inserção 
internacional que se desenvolvem a partir da atitude gerencial e a propensão a exportar

(LEONIDOU \& KATSIKEAS, 1996). Os estágios podem ser visualizados no Quadro 2.

Quadro 2: Estágios de Desenvolvimento na exportação

\begin{tabular}{|c|c|c|c|c|c|c|}
\hline 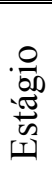 & $\begin{array}{c}\text { Johanson e } \\
\text { Wildersheim } \\
\text { (1975) }\end{array}$ & $\begin{array}{l}\text { Bilkey } \\
\text { e } \\
\text { Tesar } \\
(1977)\end{array}$ & $\begin{array}{c}\text { Cavusgil } \\
\text { (1980) }\end{array}$ & $\begin{array}{l}\text { Reid } \\
(1981)\end{array}$ & $\begin{array}{c}\text { Czinkota } \\
\text { (1982) }\end{array}$ & $\begin{array}{c}\text { Barret e } \\
\text { Wilkinson } \\
\text { (1986) }\end{array}$ \\
\hline 1 & $\begin{array}{l}\text { Sem } \\
\text { exportações } \\
\text { regulares }\end{array}$ & $\begin{array}{l}\text { Desinteressada } \\
\text { em exportação }\end{array}$ & $\begin{array}{l}\text { Mercado } \\
\text { Doméstico }\end{array}$ & $\begin{array}{l}\text { Consciência: } \\
\text { reconhece a } \\
\text { possibilidade } \\
\text { de exportar } \\
\end{array}$ & \begin{tabular}{|l} 
Desinteressada \\
em \\
Exportação
\end{tabular} & \begin{tabular}{|l|} 
Não \\
considera \\
exportação
\end{tabular} \\
\hline 2 & $\begin{array}{l}\text { Exportação } \\
\text { via agentes }\end{array}$ & $\begin{array}{l}\text { Atende } \\
\text { pedidos } \\
\text { esporádicos }\end{array}$ & $\begin{array}{l}\text { Pré- } \\
\text { exportação, } \\
\text { empresa } \\
\text { busca } \\
\text { informações e } \\
\text { avalia a } \\
\text { possibilidade. }\end{array}$ & 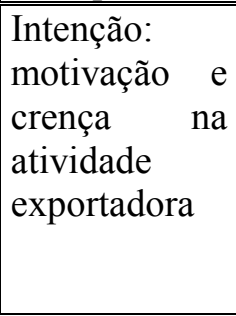 & $\begin{array}{l}\text { Interesse } \\
\text { parcial }\end{array}$ & $\begin{array}{l}\text { Busca } \\
\text { orientação } \\
\text { para mercado } \\
\text { externo }\end{array}$ \\
\hline 3 & $\begin{array}{l}\text { Exportação } \\
\text { por meio de } \\
\text { subsidiárias }\end{array}$ & $\begin{array}{l}\text { Explora a } \\
\text { possibilidade } \\
\text { de exportar }\end{array}$ & $\begin{array}{l}\text { Envolvimento } \\
\text { Experimental } \\
\text { iniciando } \\
\text { com países } \\
\text { próximos }\end{array}$ & $\begin{array}{l}\text { Julgamento } \\
\text { da atividade } \\
\text { exportadora } \\
\text { com } \\
\text { avaliação de } \\
\text { oportunidades }\end{array}$ & $\begin{array}{l}\text { Explora a } \\
\text { possibilidade } \\
\text { de exportar }\end{array}$ & $\begin{array}{l}\text { Planejamento } \\
\text { da atividade } \\
\text { exportadora }\end{array}$ \\
\hline 4 & $\begin{array}{l}\text { Unidade } \\
\text { produtiva no } \\
\text { exterior }\end{array}$ & $\begin{array}{l}\text { Exportação } \\
\text { experimental } \\
\text { para países } \\
\text { vizinhos }\end{array}$ & \begin{tabular}{lr}
\multicolumn{2}{|l}{ Envolvimento } \\
ativo & com \\
busca & de \\
novos & \\
mercados &
\end{tabular} & $\begin{array}{l}\text { Avaliação: } \\
\text { Engajamento } \\
\text { na exportação }\end{array}$ & $\begin{array}{l}\text { Inicia } a \\
\text { exportação de } \\
\text { forma } \\
\text { experimental }\end{array}$ & $\begin{array}{l}\text { Explora a } \\
\text { possibilidade } \\
\text { de se instalar } \\
\text { no exterior }\end{array}$ \\
\hline 5 & & $\begin{array}{l}\text { Torna-se } \\
\text { experiente na } \\
\text { exportação } \\
\text { para países } \\
\text { vizinhos }\end{array}$ & $\begin{array}{l}\text { Envolvimen } \\
\text { to } \\
\text { comprometi } \\
\text { do que } \\
\text { permite } \\
\text { escolhas } \\
\end{array}$ & \begin{tabular}{|ll} 
Aceitação & ou \\
rejeição da & da \\
atividade & \\
exportadora
\end{tabular} & \begin{tabular}{|l} 
Empresa \\
adquire \\
experiência \\
como pequena \\
exportadora
\end{tabular} & \\
\hline 6 & & \begin{tabular}{|l} 
Explora \\
exportação \\
para países \\
distantes e \\
diferentes \\
culturalmente
\end{tabular} & & & $\begin{array}{l}\text { Grande } \\
\text { experiência } \\
\text { exportadora }\end{array}$ & \\
\hline
\end{tabular}

Fonte: Organizado pela autora a partir das fontes citadas.

Os modelos de desenvolvimento na atividade exportadora, Quadro 2, mostram que, apesar das diferenças na quantidade de estágios, natureza do envolvimento, a exportação, 
considerada o primeiro passo no processo de inserção internacional (Figura 2), apresenta diversos estágios de envolvimento. Cada pesquisador, citado no Quadro 2, estabeleceu as fases de acordo com os grupos pesquisados e fica evidente que, mesmo que seja considerado o processo como um todo, cada fase tem características distintas, e as empresas podem apresentar competências diferentes em cada uma delas, bem como adquirir conhecimento para novos negócios.

No Quadro 2, observa-se que a partir do estágio quatro, as empresas já avaliaram e ou experimentaram a atividade exportadora e estão aptas a decidir por novos mercados, com a experiência adquirida.

Com base nos estudos realizados, apresentados no Quadro 2, as empresas desenvolvem a atividade exportadora que podem ser resumidas em três fases distintas: 1-) Iniciantes, 2-) Esporádicas e 3-) Permanentes. A primeira fase, delimitada por iniciantes na atividade exportadora, é composta por empresas que avaliam a possibilidade de exportar, porém não adotam a atividade como parte importante de sua estratégia. A segunda fase envolve exportações não regulares, mas que podem refletir, na empresa, um amadurecimento de estratégias desenvolvidas para o atendimento do mercado internacional. E, finalmente, a terceira fase é constituída por empresas que já atuam no mercado internacional, iniciando por mercados vizinhos, mas que já incorporaram a atividade exportadora e buscam o desenvolvimento de novos mercados.

As empresas exportadoras são fontes de estudo deste trabalho, ou seja, busca-se identificar as informações utilizadas pelas empresas exportadoras, que possam compor um sistema de informações necessárias para atuação no mercado internacional. 


\subsection{Informações para tomada de decisão sobre atuação no mercado externo}

O mercado internacional oferece oportunidades ilimitadas para as empresas, mas a competição é intensa. Para operar neste mercado, as empresas precisam aprender a operar e competir como se o mundo fosse um grande mercado, ignorando diferenças superficiais regionais e nacionais (JAIN, 2000). No entanto, há necessidade de preparo para usufruir dos benefícios de economia de escala na produção, distribuição, marketing e gerenciamento.

Segundo Carvalho (2003), no ambiente de negócios internacionais existe uma lacuna experimentada pelos dirigentes de empresas, que têm dificuldade de operar com dimensões de informações. Torna-se então necessário criar um sistema de inteligência sobre mercados internacionais, que permita identificar e aproveitar as oportunidades, mantendo o sistema como ativo estratégico que é a análise continuada dos mercados externos.

A empresa que decide pela inserção internacional enfrenta muitas decisões que, segundo Keegan (2005) podem ser delimitadas pela seleção de países utilizando os critérios: proximidade geográfica, cultura, idioma e concorrência.

Lloyd-Reason et al. (2000) destacam que as empresas não estão imunes ao impacto da inserção internacional. Além da posição da empresa é necessário o envolvimento do gestor e o seu comportamento será fundamental para influenciar e decidir sobre a entrada no mercado internacional.

Cadogan et al. (1999) elaboraram um modelo conceitual para o mercado internacional baseado no comportamento e na integração da empresa. Neste modelo, os componentes 
principais são a inteligência de exportação, a disseminação de informações, responsividade e coordenação.

Considerando o processo de inserção internacional das empresas, alguns fatores são determinantes: conhecimento, atitude e motivação (CAVUSGIL \& NEVIN, 1981; CHETTY, 1999). A decisão de se inserir no comércio internacional é influenciada por crenças e percepções das vantagens, riscos associados, barreiras internas e externas e uma das grandes barreiras, segundo Johanson \& Vahlne (1977), é a falta de conhecimento sobre os mercados internacionais.

O processo de aquisição de informação pode ser caracterizado como o modo como essas informações são obtidas, os recursos utilizados na coleta e o fluxo de informação gerado desde o fornecedor até o usuário. A informação é utilizada quando se enquadra na necessidade de tomar decisões (KEEGAN, 2005).

Segundo Keegan (2005), o gestor de uma empresa necessita saber onde e como obter informações das áreas e os assuntos que devem ser cobertos. Uma vez obtidas as informações, estas devem ser processadas de modo a gerar idéias e ou avaliações de estratégias e cursos de ação a serem adotadas pelas empresas exportadoras.

Para Leonidou \& Katsikeas (1996), a inserção internacional das empresas é um processo no qual estão implícitos facilitadores e inibidores para exportação, informações requeridas e adquiridas, seleção de mercados e estratégia de entrada. As informações são abordadas pelos autores, em dois focos principais: 
a- Informações Necessárias - Estas informações podem ser obtidas por meio de dados estatísticos divulgados por organismos governamentais ou por empresas especializadas no país onde a empresa está localizada.

b- Aquisição de Informações - São as informações do mercado alvo e que são adquiridas diretamente com o país alvo.

A quantidade e a qualidade das informações que as empresas exportadoras utilizam, dependem da experiência internacional. À medida que a empresa alcança novos mercados, a necessidade de informações será crescente. (LEONIDOU \& KATSIKEAS, 1996).

Em países industrializados, os órgãos governamentais têm disponibilizado serviços de informação para suprir as necessidades de informação para exportação (CZINKOTA e JOHSON, 1981; POSNER, 1980; HILL, 2005; WOOD e ROBERTSON, 2000) e uma das preocupações é se estas informações, disponibilizadas pelos provedores, atendem as necessidades das empresas envolvidas com negócios internacionais (CHAUDRY e CRICK, 1998; SOUCHON e DIAMANTOPOULOS, 1997).

A partir das considerações anteriormente citadas, serão analisados referenciais teóricos e empíricos específicos que possibilitem modelar um sistema de inteligência de mercado internacional composto de informações necessárias para atuação internacional, utilizado por empresas brasileiras exportadoras. 


\subsubsection{Inteligência de Mercado para Alta Gerência}

A expressão "Inteligência de Mercados" foi proposta pela primeira vez por William T. Kelley em 1961 (KELLEY, 1965), sendo, a partir de então, adotada por empresas norte americanas como um departamento diretamente ligado à alta gerência (Figura 3).

Figura 3: Organização da Divisão de Serviço de Inteligência

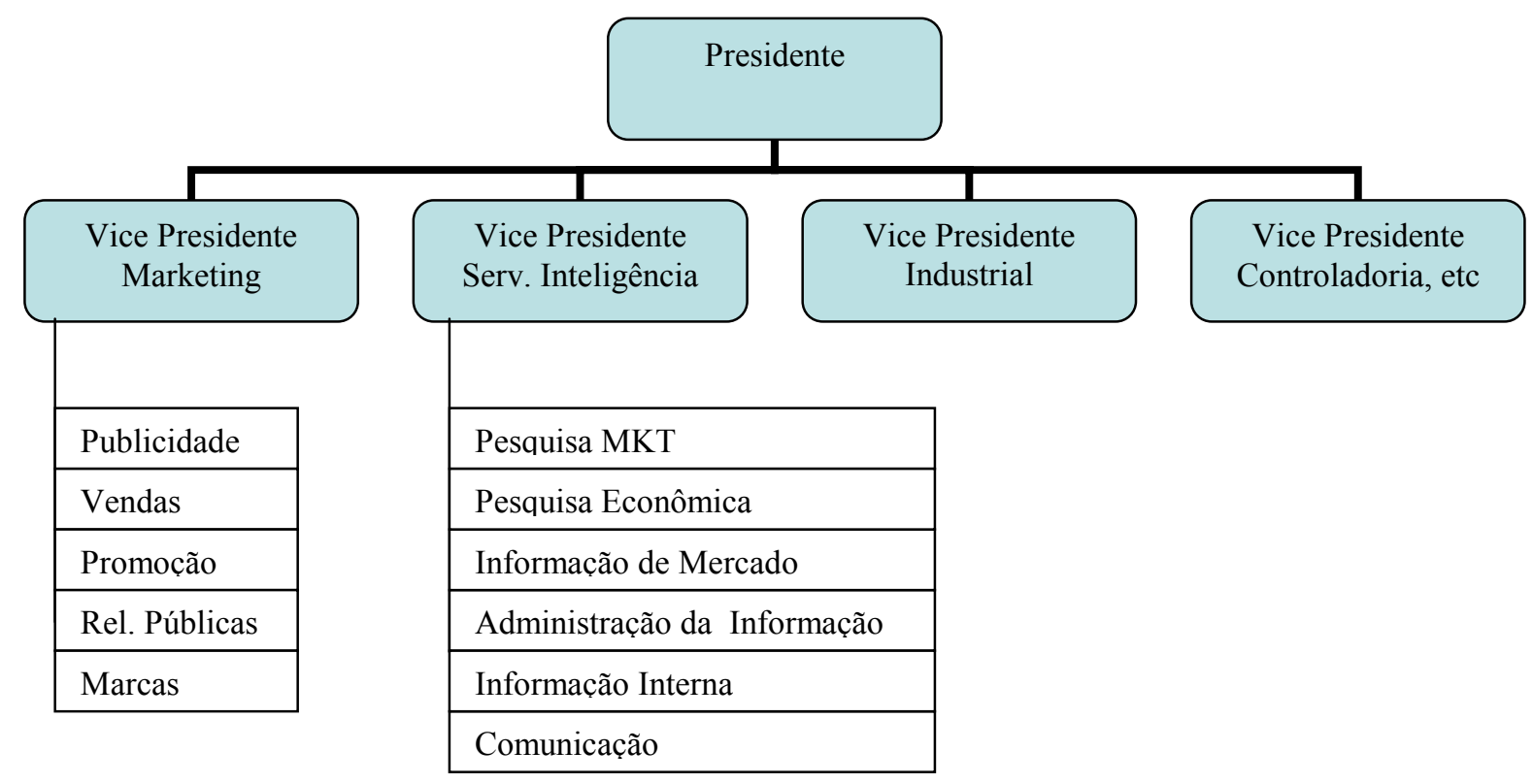

Fonte: Adaptado de Kelley, 1965.

A função do Serviço de Inteligência, mostrado na Figura 3, descrito por Kelley (1965) é fornecer toda informação necessária para a tomada de decisão do escalão maior da empresa. Neste departamento estão vinculadas seis principais funções: pesquisa de marketing, pesquisa econômica, informações de mercado, administração da informação, informação interna e comunicação. 
Para chegar ao modelo, Kelley (1968) classifica o fluxo da informação como interna e externa, de modo que a empresa identifique as categorias de informação que possam ser pesquisadas e utilizadas pela empresa. O fluxo externo contém as duas maiores categorias de informação, que são as informações econômicas e mercadológicas. O fluxo interno é o processo que dissemina a informação dentro da empresa de modo a armazenar e gerenciar para o processo decisório.

O modelo descrito na Figura 3 foi concebido a partir do reconhecimento da importância de um sistema de informação e pesquisa, focado no mercado, tanto interno quanto externo. Segundo Kelley (1968) as principais vantagens deste sistema são:

1- Melhor preparo para obtenção de informação - o incremento dos negócios torna complexo o processo de obtenção e aproveitamento de informação e, neste caso, a empresa está capacitada a selecionar as informações necessárias.

2- Melhor produção da inteligência final - o fluxo de informação são coletadas e convertidas em um fluxo monitorado pela empresa.

3- Redução da confusão da informação do mercado - possibilita a selecionar as informações que serão utilizadas na tomada de decisão.

4- Prevenção da distorção da informação - a centralização evita que as informações sejam obtidas por diversos departamentos e gerem distorções até chegar ao tomador de decisão.

5- Novas e melhores fontes de informação - a empresa estará habilitada a encontrar o melhor caminho para obter informações, conhecendo as melhores fontes.

6- Função da inteligência criativa - o cruzamento das informações permite elaborar um sistema criativo que gera a inteligência. 
O resultado do sistema de informação proposto por Kelley (1965) é a expansão dos negócios - as informações coletadas proporcionam visão de negócios mais precisa, avaliação e controle dos dados obtidos e confrontados com os resultados.

O modelo de Kelley (1965) é um primeiro passo para o aprofundamento do sistema de inteligência de mercado, que foi proposto por outros autores e que serão apresentados a seguir.

\subsubsection{Modelo de Inteligência de Mercado Internacional de Keegan}

A finalidade do sistema de informação de marketing, segundo Keegan (2005), é fornecer aos tomadores de decisão um fluxo contínuo de informações sobre mercados, clientes, concorrentes e operações da empresa, de maneira possibilitem coletar, analisar, classificar, armazenar, recuperar dados dos elementos coletados.

Quadro 3: Modelo de Sistema de Inteligência Internacional de Keegan

\begin{tabular}{|l|l|}
\hline \multicolumn{1}{|c|}{ Categoria } & \multicolumn{1}{|c|}{ Abrangência } \\
\hline \hline 1- Mercados & $\begin{array}{l}\text { Estimativa de demanda, comportamento do consumidor, } \\
\text { produtos, canais, disponibilidade e custo de sistemas de mídia e } \\
\text { capacidade de resposta do mercado. }\end{array}$ \\
\hline \hline 2-Competição & Estratégias e planos funcionais, corporativos e de negócios. \\
\hline \hline 3-Intercâmbio Estrangeiro & $\begin{array}{l}\text { Equilíbrio de pagamentos, taxa de juros, atratividade da moeda } \\
\text { do país, expectativa dos analistas. }\end{array}$ \\
\hline 4-Informações Prescritivas & $\begin{array}{l}\text { Leis, regulamentos, taxas em vigor, rendimentos, dividendos } \\
\text { tanto do país de origem como do país que recebe investimentos. }\end{array}$ \\
\hline \hline 5-Informações Complementares & $\begin{array}{l}\text { Disponibilidade de recursos humanos, físicos, financeiros e } \\
\text { informacionais. }\end{array}$ \\
\hline \hline 6-Condições Gerais & Visão geral dos ambientes sociocultural, político e tecnológico. \\
\hline
\end{tabular}


Segundo Keegan (2005), o ponto de partida para elaboração de um Sistema de Inteligência de Mercados Internacionais é a relação de assuntos sobre os quais se deseja obter informações, e deve atender às necessidades e objetivos específicos da empresa.

O Quadro 3 mostra as categorias de assuntos agrupadas por seis amplas áreas de informação. Considerando que o modelo é geral e que cada empresa deve encontrar uma metodologia ideal, pode-se concluir que as categorias de assuntos podem não se adequar à pequenas e médias empresas, bem como para as empresas brasileiras. Cada item é relevante para uma empresa atuante no mercado internacional, porém, pode-se observar que a categoria dois (Quadro 3) que trata da competição, pode ser adaptada considerando a concorrência internacional, visto que abordar planos corporativos de negócios pode estar mais adequado a empresas que possuem unidades estratégicas no exterior, em forma de investimento estrangeiro direto, seja na modalidade de produção, seja na instalação de escritório de representação e vendas.

Da mesma forma, o item cinco (Quadro 3), que trata de informações complementares, Keegan (2005), abrange a disponibilidade de recursos humanos, físicos, financeiros e informacionais, que podem não se adequarem a realidade das empresas brasileiras, se não considerarem estas informações relevantes para atuação no mercado internacional. (CARVALHO, 2003)

O modelo proposto por Keegan (2005) na Tabela 6 tem a vantagem de agrupar as informações em categorias de forma a abranger todas as informações consideradas relevantes para atuação no mercado internacional. Nesta ótica, a empresa pode acrescentar informações adequadas a sua área de atuação, excluindo as não relevantes, o que pode sugerir um 
aperfeiçoamento do padrão inicial visando atingir os objetivos da empresa à medida que esta se compromete mais com o mercado internacional.

\subsubsection{Modelo de Inteligência de Mercado Internacional de Dowle \& Lowe}

Segundo Dowle \& Lowe (2004) as empresas precisam de um sistema para identificar as oportunidades do mercado internacional, sendo este o objetivo da elaboração de um Sistema de Informação de Mercados. Este primeiro passo precisa seguir uma seqüência de passos antes de implantar efetivamente um Sistema de Informação de Mercados, que estão descritos a seguir:

1- Identificar os países que têm infra-estrutura para a distribuição do produto e que são acessíveis à empresa

2- Elaborar uma lista de países com critérios semelhantes

3- Desenvolver micro segmentos nos países alvo, identificando comportamento do consumidor, exigências requeridas pelo mercado.

4- Cruzar as informações para identificar as características de mercado de cada segmento.

5- Análise de cluster para identificar similaridades dos mercados para a elaboração de um plano estratégico direcionado.

Segundo Dowle \& Lowe (2004), a partir de então, as empresas podem construir um sistema que é apresentado no Quadro 4. 
Quadro 4: Modelo de Análise de Mercado Internacional de Dowle \& Lowe

\begin{tabular}{|l|l||}
\hline \multicolumn{1}{|c|}{ Categorias } & \multicolumn{1}{c|}{ Abrangência } \\
\hline \hline 1-País Alvo & Informações gerais e impacto das dimensões do ambiente. \\
\hline \hline 2-Concentração & Estrutura do segmento do mercado e propagação geográfica \\
\hline \hline 3-Consumidor & $\begin{array}{l}\text { Características do país, grupos culturais, influências no comportamento } \\
\text { de compra. }\end{array}$ \\
\hline \hline 4-Decisões & Suprimentos, concorrência, forças e fraquezas competitivas. \\
\hline \hline 5-Consumo & $\begin{array}{l}\text { Demanda e análise econômica, potencial de crescimento setorial e } \\
\text { potencial de produtos substitutos. }\end{array}$ \\
\hline \hline 6-Obrigações Contratuais & Práticas de negócios, obrigações legais e seguro. \\
\hline 7-Compromisso & $\begin{array}{l}\text { Acesso ao mercado, incentivos e barreiras ao comércio, tarifas } \\
\text { alfandegárias. }\end{array}$ \\
\hline \hline 8-Canais & $\begin{array}{l}\text { Comportamento compra, capacidade de intermediários, distribuição } \\
\text { física, cobertura dos custos de distribuição, infra-estrutura do país. }\end{array}$ \\
\hline \hline 9-Comunicação & Promoção, custos, práticas comerciais comuns e propaganda. \\
\hline \hline $\begin{array}{l}\text { 10-Capacidade } \\
\text { Pagamento }\end{array}$ & Preço, cultura de preços, condições de pagamento, garantias. \\
\hline \hline 11-Moeda Corrente & Estabilidade, restrições e controle de trocas pelo governo. \\
\hline \hline
\end{tabular}
Fonte: Dowle \& Lowe, 2004.

O objetivo do modelo (Quadro 4) é, segundo Dowle \& Lowe (2004), habilitar a empresa a usar as informações do ambiente para construção de um sistema que permita identificar oportunidades e restrições nos mercados potenciais.

O modelo (Quadro 4) pode ser considerado bem detalhado e algumas informações se repetem nos itens que trata de consumidor (item 3) e consumo (item 5) e que poderiam estar agrupadas de forma a simplificar o controle de informações pela empresa. $O$ item sete que trata de compromissos engloba informações que podem ser abordadas no país alvo, pois estas informações podem ser específicas para um país. Como vantagem, o modelo pode ser considerado importante e bem elaborado, partindo do princípio que os autores (DOWLE \& LOWE, 2004) recomendam a utilização de uma fase preliminar antes da elaboração do plano de análise de informação dos mercados. 


\subsubsection{Modelo de Inteligência de Mercado Internacional de Hill}

Hill (2005) cita que participar do mercado internacional requer uma análise e preparação cuidadosa. Esta preparação envolve quatro fases específicas:

Fase 1- Examinar os aspectos formadores do mercado global, a influência da globalização, modernização e ocidentalização, e através da observação dos aspectos geográficos e históricos podem refletir no desenvolvimento econômico e na cultura regional.

Fase 2 - Os efeitos dos aspectos da Fase 1 são analisadas de forma regionalizada. Este processo envolve investigar a história nacional, em seus aspectos geográficos, políticos, econômicos e a posição internacional vista por outros países e analistas de mercado.

Fase 3 - Analisar, dentro do mercado, os competidores, a formação industrial, comercial e de serviços. Esta análise permite visualizar os concorrentes, a política comercial utilizada no mercado, preços, consumidores, canais de distribuição e forma de atuação permitindo subsidiar estratégias para a inserção neste mercado.

Fase 4 - A partir do conhecimento e delineamento das características do mercado, esta fase consistirá na elaboração de um planejamento internacional.

A Figura 4 mostra a forma como pode ser desenvolvida esta estratégia

Figura 4- Análise Internacional de Mercados de Hill

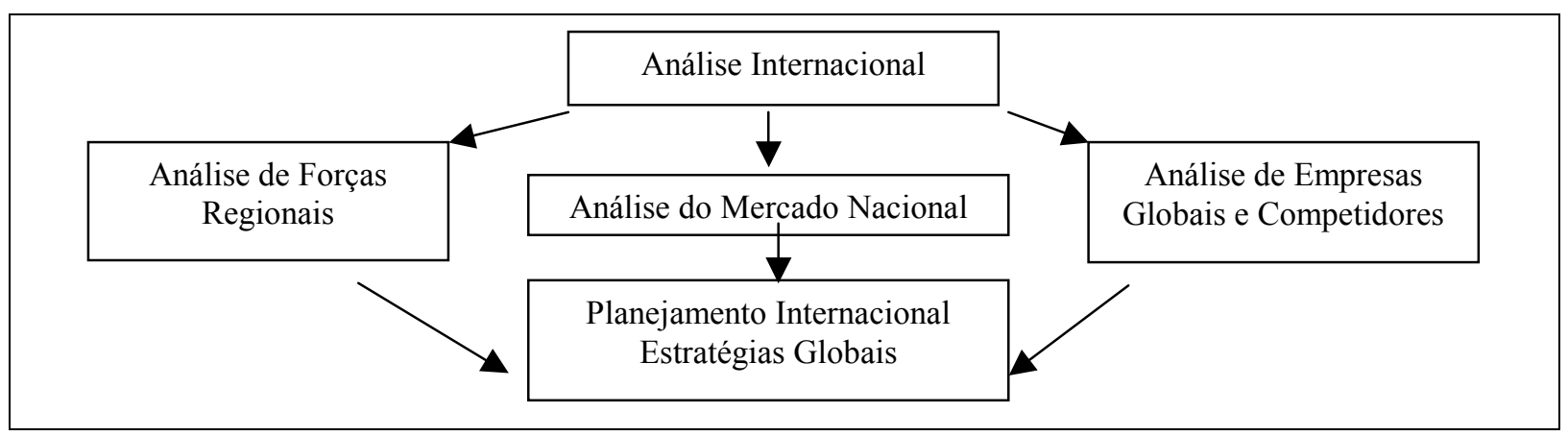

Fonte: Hill (2005) 
De acordo com Hill (2005), pode se observar na Figura 4 que a análise internacional é baseada em aspectos conjuntos da análise do mercado nacional, das forças regionais e das empresas globais e dos competidores. Nessa perspectiva pode se chegar a um planejamento internacional adotando-se estratégias globais.

Hill (2005) considera que o conhecimento do mercado internacional começa com o entendimento das características históricas e geográficas que permitam ao empresário determinar os pontos chave do patrimônio político, econômico e cultural dos países. Estes aspectos permitem uma análise do mercado onde se pretende atuar e que pode ser visualizado no Quadro 5.

Quadro 5: Inteligência de Mercados Internacionais de Hill

\begin{tabular}{|l|l||}
\hline \multicolumn{1}{|c|}{ Categoria } & \multicolumn{1}{c|}{ Abrangência } \\
\hline \hline 1- Bases Essenciais & Influência histórica e geográfica \\
\hline \hline 2-Situação Atual & Estrutura política, econômica e financeira do país. \\
\hline \hline 3-Análise Comercial & Indústria, demanda, suprimentos e ambiente de negócios \\
\hline \hline 4-Cultural & Visão geral dos ambientes sociocultural. \\
\hline
\end{tabular}

Fonte: Hill, 2005.

Segundo Hill (2005), os países tendem a se desenvolver de forma diferente, apresentando diferenças culturais e particularidades nacionais. São várias categorias a analisar culturalmente um país que envolve: aspectos físicos, geográficos, colonização, religião, idiomas, saúde, relações pessoais, estilos de vida, atitudes, recreação, escolaridade e outros que podem subsidiar as decisões de uma empresa ao focar um mercado. 
No Quadro 5, o item 1, que trata das bases essenciais, busca informações históricas e geográficas para o entendimento da formação dos aspectos regionais e nacionais relevantes. Para Hill (2005) a história dos países é responsável pelas circunstâncias ambientais e proporcionam compreensão da cultura e comportamento dos consumidores

O item 2 (Quadro 5) aborda as informações sobre a estrutura política, econômica e financeira dos países, que são fatores, segundo Hill (2005) que podem influenciar os negócios internacionais.

Após encerrar a investigação política, econômica e financeira de um país, pode ser iniciada a avaliação comercial (item 3). Esta avaliação compreende segundo Hill (2005), primeiramente a análise industrial, enfocando consumo, produção, concorrentes e estrutura do mercado. Em segundo lugar, uma análise da demanda, concentrando as informações nos consumidores, segmentação e pesquisas em marketing que forneçam informações sobre a demanda no mercado em foco. Em terceiro lugar, uma análise de suprimentos, que considera a avaliação de possíveis fornecedores no mercado, como opção de instalar uma unidade no país alvo. Isso implica em investigar os aspectos deste mercado, as tarifas, barreiras, custos de instalação, investimentos, disponibilidade de mão-de-obra, legislação e custos operacionais para este mercado. A quarta análise envolve o ambiente de negócios, que além dos aspectos já analisados: indústria, demanda, suprimentos, outras duas áreas merecem atenção: aspectos financeiros e infra-estrutura legal. No aspecto financeiro: mercado de capitais, tributação e câmbio (taxa de conversão e credibilidade). A infra-estrutura legal define aceitabilidade de capital estrangeiro e as restrições impostas pelo governo e sociedade locais (monopólio, antitruste, lei de proteção ao consumidor e propriedade intelectual). 
O item 4 do Quadro 5 mostra que deve ser incluído no sistema de informação o aspecto cultural, que proporcionará uma visão geral do ambiente sócio-cultural.

Além dos aspectos já mencionais, Hill (2005) sugere uma análise dos competidores globais que requer dos executivos um entendimento básico das forças que influenciam o mercado internacional. Para esse entendimento é necessário focalizar como estas forças afetam o ambiente global das empresas e competidores.

O modelo de Hill (2005), assim como os modelos apresentados nos item anteriores, deve ser aplicado levando-se em consideração a empresa atuante no mercado, os países alvo, e o produto.

\subsubsection{Inteligência de Mercado Internacional aplicado ao comércio exterior brasileiro.}

Os modelos apresentados abordam sistemas de informação que permitam análise dos mercados internacionais considerando as dimensões de informações que possam abranger diversos mercados, bem como podem ser adaptados de acordo com a necessidade da empresas (KEEGAN, 2005; DOOLE \& LOWE, 2004).

As estratégias devem ter por base os mercados alvo e a escolha dos segmentos de clientes a serem atingidos. A inserção internacional pressupõe a entrada em vários mercados, mas com características diferentes e é praticamente impossível satisfazer a todos os consumidores com apenas um produto ou serviço (LAMBIN, 2000) 
Observa-se que os modelos apresentam vantagens e desvantagens discutidas em cada tópico, e contém similaridades que podem ser reagrupadas. Para que os modelos possam ser aplicados às empresas brasileiras exportadoras, torna-se necessário discutir as categorias de informações teoricamente relevantes para o exportador.

\subsection{O Ambiente de Negócios Internacionais}

O aumento da concorrência e a instabilidade nas condições de mercado levam as empresas a pensarem no mercado como sendo global e não mais como mercado doméstico ou interno e estrangeiro ou externo. A inserção da empresa no mercado internacional e as sinergias resultantes deste processo alteram o referencial da empresa na determinação da produtividade exigida e do alcance de suas ações de marketing.

O primeiro aspecto a ser considerado é a visualização do macro ambiente dos negócios internacionais, que proporciona uma análise muldimensional, complexa e influencia nas estratégias de marketing internacional (DOOLE \& LOWE, 2004).

Figura 5: Influências do ambiente no marketing internacional

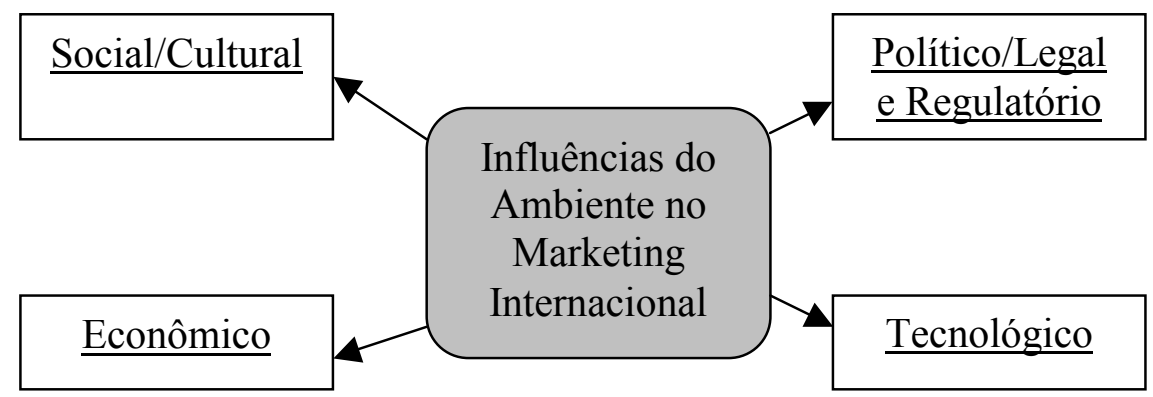

Fonte: Doole \& Lowe (2004) 
A Figura 5 mostra que o ambiente de negócios internacionais sofre a influência do macroambiente, em que devem ser considerados os aspectos sócio-cultural, legal, político, econômico e tecnológico. Segundo Doole \& Lowe (2004) a diferença chave entre o marketing doméstico e o marketing internacional é a complexidade desses fatores que mudam de acordo com o país alvo de negócios.

O modelo descrito na Figura 5 também é explicado por Keegan (2005) e Hill (2005). Segundos os dois autores, as influências do ambiente internacional podem determinar oportunidades no mercado. Com base nessa descrição, torna-se importante analisar cada ambiente, e as informações demandadas que podem influenciar as decisões na inserção internacional das empresas.

\subsubsection{O Ambiente Sócio Cultural}

As diferenças sociais e culturais entre os países são muitas (DOOLE \& LOWE, 2004) e um grande desafio para o marketing internacional porque são ocultas (KEEGAN, 2005). As diferenças sociais, idiomas, religião, estilo de vida e valores são aspectos do ambiente social e cultural que afetam a percepção dos consumidores e o comportamento de compra (DOOLE \& LOWE, 2004). Cada um destes elementos varia entre os países, podendo ser essencial na determinação estratégica de entrada no mercado internacional (JAIN, 2000).

Segundo Keegan (2005) alguns produtos podem sofre maior ou menor influência do ambiente social e cultural. O autor cita que os produtos industriais podem ter baixos níveis de sensibilidade ao ambiente em comparação com os produtos de consumo. 


\subsection{2. - O Ambiente Econômico}

Segundo Keegan (2005), a observação do ambiente econômico permite categorizar os países alvo em termos de estágio de desenvolvimento econômico e renda da população. Em cada país, as informações econômicas indicam estimativas do Produto Interno Bruto (PIB), consumo, investimentos, reservas internacionais, paridade cambial, níveis de preço, cuja análise e comparação com outros países pode ser utilizada para elaboração de um plano para a atuação no mercado global (KEEGAN, 2005).

O entendimento deste ambiente é importante para identificar a infra-estrutura comercial, tais como os acordos comerciais desenvolvidos pelo país, como o governo conduz política econômica, que podem ser identificados por meio de informações da produção interna, inflação e taxa de conversão da moeda local (DOOLE \& WOLE, 2000).

As informações geradas no ambiente econômico permitem identificar nos estágios de desenvolvimento distintos e formular estimativas gerais sobre o tipo de demanda associada ao estágio de desenvolvimento econômico, e pode ser um importante indicador do potencial de um país ou região (KEEGAN, 2005).

\subsubsection{O Ambiente Político Legal e Regulatório}

O ambiente político inclui fatores que podem afetar as operações das organizações. Segundo Keegan (2005) as atividades do marketing internacional ocorrem dentro de um ambiente de instituições governamentais pelas quais o povo e o governo exercem o poder. As empresas que atuam fora de seu país de origem devem estudar cuidadosamente a estrutura 
governamental em que são formuladas as leis, regulamentos e diretrizes políticas (KEEGAN, 2005).

As ações governamentais podem se constituir em potencial risco para as empresas que querem entrar no mercado internacional, e podem resultar em restrições operacionais, discriminações exercidas por meio de tarifas e barreiras ao comércio de produtos estrangeiros e leis que podem dificultar o exercício do direito no ambiente internacional (DOOLE \& LOWE, 2000).

O ambiente legal, segundo Keegan (2005) deve ser observado, pois envolvem as empresas que colocam seus produtos em outro mercado, podem não ser protegidas em seus direitos autorais, patentes, marcas e, que podem levar a falsificações e reproduções sem autorização o que serão extremamente danoso à empresa atuante neste mercado. Este ambiente demanda conhecimento de como o país alvo aborda as resoluções de conflitos.

Associado ao aspecto político e legal, há que se considerar o ambiente regulatório, que é administrado por órgãos governamentais responsáveis pelas diretrizes de comercialização (KEEGAN, 2005). A influência das agências reguladoras é, segundo Keegan (2005), difusa e a compreensão de como operam é essencial no ambiente de negócios, visto que operam na regulação de preços, etiquetagem, regulamentação de propaganda, alimentos, medicamentos e padrões de qualidade.

\subsubsection{O Ambiente Tecnológico}

O impacto do ambiente tecnológico, segundo Doole \& Wole (2004), pode refletir em todas as ações do marketing internacional, o que implica em ter habilidades para acumular 
dados, gerenciar e controlar as informações atualizadas. Este ambiente pode ser favorável ao desenvolvimento e acompanhamento dos negócios internacionais, pois os países alvo podem apresentar diferenças do desenvolvimento tecnológico, dificultando o acompanhamento das informações pelas empresas exportadoras.

Os ambientes descritos demonstram que a análise das variáveis é importante e pode influenciar o desempenho exportador das empresas atuantes no mercado internacional. Desta forma, é importante conhecer o ambiente internacional, por meio do desenvolvimento de um sistema de informação que possibilite um direcionamento das decisões empresariais e reflita um bom desempenho neste mercado.

Pode-se observar que estes ambientes, ao serem analisados, implicam em riscos para as empresas que atuam no mercado internacional. A proposta deste trabalho está delimitada em conhecer as informações utilizadas pelas empresas exportadoras na atuação no mercado internacional, e não pretende quantificar o risco dos negócios, pois este tema pode ser investigado com estudos mais aprofundados.

O Quadro 6 apresenta, de forma agrupada, as variáveis que envolvem cada ambiente já descrito. Estas variáveis serão utilizadas para investigar a fonte destas informações utilizadas pelas empresas exportadoras. 
Quadro 6: Ambiente de Negócios Internacionais

\begin{tabular}{|c|c|}
\hline Ambiente & Variáveis \\
\hline Sócio Cultural & Religião, idiomas, estilo de vida, valores e atributos. \\
\hline Econômico & Inflação, Renda per capita, PIB, Desemprego, paridade cambial, Reservas Internacionais. \\
\hline $\begin{array}{l}\text { Político Legal e } \\
\text { Regulatório }\end{array}$ & $\begin{array}{l}\text { Estabilidade, relações diplomáticas, liderança no país alvo, tarifas, barreiras não tarifárias, } \\
\text { proibições, regulamentos, acordos comerciais, proteção a propriedade intelectual. }\end{array}$ \\
\hline Tecnológico & Disponibilidade de rede de comunicações no país alvo \\
\hline
\end{tabular}

Fonte: Organizado pela autora a partir das fontes citadas.

Caracterizado o ambiente de negócios internacionais, torna-se necessário, discutir a dimensão das informações mercadológicas teoricamente relevantes para o exportador brasileiro, que os modelos apresentados citam como base para um sistema de informações que serão objeto de pesquisa com as empresas brasileiras exportadoras.

\subsection{Informações requeridas para os negócios internacionais}

A decisão estratégica de buscar o mercado internacional tem suas dificuldades dentro da própria empresa, habituada às condições de competição, nível de exigência da demanda vigentes no mercado doméstico. Começar a exportar significa integrar à sua estrutura, procedimentos de decisão e rotinas de produção uma nova dimensão da atividade empresarial, com regras e códigos próprios gerando custos e riscos específicos. Consolidar-se na atividade exportadora implica em aumentar a sua aposta: adaptar produtos e processos de produção, investir em desenvolvimento de mercados, atender a normas técnicas e ambientais não existentes no mercado doméstico, reduzir preços para manter-se competitivo, buscar mecanismos de apoio financeiro e, contemplar, em sua estratégia de investimentos, a variável exportação (VEIGA, 2002; MINERVINI, 2005; PALÁCIOS \& SOUSA, 2004). 
Minervini (2005) destaca que a maior carência nos processos de negociação é a informação e, em conseqüência, a maior causa dos fracassos. $O$ autor elaborou um levantamento das informações necessárias para uma empresa que se prepara para entrar no mercado internacional que pode ser visualizado no Quadro 7.

Quadro 7: Visão macro do universo de informações

\begin{tabular}{|c|c|c|c|}
\hline No. & Tipo de Informação & O porquê da Informação & Possíveis Fontes \\
\hline 1 & $\begin{array}{l}\text { Imagem do seu país no } \\
\text { exterior }\end{array}$ & $\begin{array}{l}\text { A imagem do país reflete na } \\
\text { motivação do importador }\end{array}$ & $\begin{array}{l}\text { Meios de comunicação } \\
\text { Imprensa estrangeira } \\
\text { Embaixadas/Consulados }\end{array}$ \\
\hline 2 & $\begin{array}{l}\text { Exportações do seu } \\
\text { produto por competidores } \\
\text { locais }\end{array}$ & $\begin{array}{l}\text { Avaliar se o seu produto é } \\
\text { exportado como o deles }\end{array}$ & $\begin{array}{l}\text { Feiras Internacionais } \\
\text { Câmaras de Comércio } \\
\text { Instituições de Apoio à } \\
\text { exportação } \\
\text { Estatísticas de secretarias de } \\
\text { indústria e comércio }\end{array}$ \\
\hline 3 & 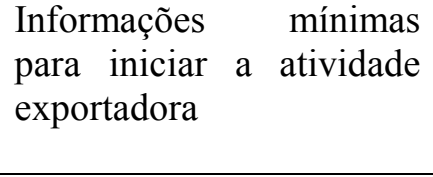 & $\begin{array}{l}\text { Conhecer a seqüência correta } \\
\text { dos procedimentos }\end{array}$ & $\begin{array}{l}\text { Centros de treinamento } \\
\text { Consultores } \\
\text { Instituições estrangeiras de } \\
\text { promoção do comércio exterior }\end{array}$ \\
\hline 4 & $\begin{array}{l}\text { Oportunidade } \\
\text { exportação }\end{array}$ & $\begin{array}{l}\text { Saber quem está comprando ou } \\
\text { quem quer comprar produtos } \\
\text { similares ao seu. }\end{array}$ & $\begin{array}{ll}\text { Instituições nacionais } & \text { de } \\
\text { comércio exterior } & \\
\text { Boletim de Câmaras de } \\
\text { comércio bilaterais } \\
\text { Revistas Especializadas } \\
\text { Consultores } \\
\end{array}$ \\
\hline 5 & $\begin{array}{l}\text { Pesquisas de mercado já } \\
\text { existentes }\end{array}$ & $\begin{array}{l}\text { Para utilizar as informações já } \\
\text { disponíveis e não investir muito } \\
\text { em novas pesquisas }\end{array}$ & $\begin{array}{l}\text { Câmaras setoriais } \\
\text { Centros de Estudo } \\
\text { Bancos internacionais } \\
\text { Universidades } \\
\text { Centros de Negócios } \\
\text { Internacionais }\end{array}$ \\
\hline 6 & Acordos Internacionais & $\begin{array}{l}\text { Analisar possíveis vantagens em } \\
\text { utilizar os mecanismos que } \\
\text { facilitam o comércio }\end{array}$ & $\begin{array}{l}\text { Embaixadas } \\
\text { Câmaras de Comércio } \\
\text { bilaterais } \\
\text { Bibliografia especializada }\end{array}$ \\
\hline 7 & $\begin{array}{l}\text { Normas } \\
\text { relacionadas } \\
\text { produto }\end{array}$ & $\begin{array}{l}\text { Conhecer os requisitos dos } \\
\text { países importadores }\end{array}$ & $\begin{array}{l}\text { Escritórios de promoção } \\
\text { comercial } \\
\text { Câmaras de comércio bilaterais } \\
\text { Missões ao exterior } \\
\text { Revistas Especializadas } \\
\text { Catálogo de concorrentes } \\
\text { Empresas especializadas em } \\
\text { consultoria de exportação } \\
\text { Seminários Internacionais }\end{array}$ \\
\hline
\end{tabular}




\begin{tabular}{|c|c|c|c|}
\hline 8 & Feiras Internacionais & $\begin{array}{l}\text { Avaliar qual feira é a mais } \\
\text { adequada ao seu produto }\end{array}$ & \begin{tabular}{|l|} 
Câmaras de Comércio \\
Escritórios de promoção \\
comercial \\
Instituições especializadas \\
\end{tabular} \\
\hline 9 & $\begin{array}{l}\text { Legislação de importação } \\
\text { do país de interesse }\end{array}$ & $\begin{array}{l}\text { Conhecer os procedimentos e } \\
\text { eventuais barreiras a serem } \\
\text { enfrentadas }\end{array}$ & $\begin{array}{l}\text { Escritórios de promoção } \\
\text { comercial } \\
\text { Câmaras de comércio bilaterais } \\
\text { Consultores }\end{array}$ \\
\hline 10 & $\begin{array}{l}\text { Sistema econômico, } \\
\text { político, social e e } \\
\text { financeiro. }\end{array}$ & $\begin{array}{l}\text { Conhecer o } r \text { quadro } \\
\text { macroeconômico do país e } \\
\text { avaliar a conveniência de fazer } \\
\text { ou não negócios }\end{array}$ & $\begin{array}{l}\text { Embaixadas } \\
\text { Câmaras de Comércio } \\
\text { Bibliografia especializada } \\
\text { Institutos de promoção do } \\
\text { comércio exterior }\end{array}$ \\
\hline 11 & $\begin{array}{lr}\text { Perfil do } & \text { mercado } \\
\text { (concorrência, } & \text { preços, } \\
\text { embaixadas } & \mathrm{e} \\
\text { comunicação) } & \end{array}$ & $\begin{array}{l}\text { Traçar um plano de entrada } \\
\text { nesse mercado }\end{array}$ & $\begin{array}{l}\text { Empresas de pesquisa } \\
\text { Viagens ao Exterior } \\
\text { Feiras Internacionais } \\
\text { Institutos de promoção do } \\
\text { comércio exterior } \\
\text { Consultores }\end{array}$ \\
\hline 12 & Possíveis financiamentos & $\begin{array}{l}\text { Avaliar a possibilidade de } \\
\text { reduzir custos financeiros }\end{array}$ & $\begin{array}{l}\text { Bancos em geral, habilitados } \\
\text { ao comércio exterior. } \\
\text { Consultores especializados }\end{array}$ \\
\hline 13 & Contratos & $\begin{array}{l}\text { Evitar erros em assuntos de } \\
\text { marca, condição de vendas e } \\
\text { controle de agentes. }\end{array}$ & $\begin{array}{l}\text { Escritório de advogados } \\
\text { especializados } \\
\text { Câmaras de comércio bilaterais }\end{array}$ \\
\hline 14 & $\begin{array}{l}\text { Publicações } \\
\text { comércio exterior }\end{array}$ & $\begin{array}{l}\text { Criar um banco de dados } \\
\text { renovável }\end{array}$ & $\begin{array}{l}\text { Câmaras de Comércio } \\
\text { bilaterais } \\
\text { Instituições de promoção do } \\
\text { comércio exterior } \\
\text { Empresas especializadas em } \\
\text { consultoria de exportação }\end{array}$ \\
\hline
\end{tabular}

Fonte: Minervini (2005)

Minervini (2005) destaca que ao realizar uma pesquisa preliminar, a empresa economiza tempo e recursos, principalmente quando se busca um mercado pouco conhecido, ou que ainda não é tradicional comprador dos produtos do país de origem. Mesmo que a empresa considere a possibilidade de exportar como um objetivo a médio prazo, é importante que se busque informações, cujo resultado irá refletir na conquista de novos mercados.

Observam-se no Quadro 7 que algumas fontes podem fornecer vários tipos de informações que podem ser agrupadas em quatro focos principais (Quadro 8), segundo Minervini (2005). 
Quadro 8: Sumário de Informações Necessárias

\begin{tabular}{|c|c|}
\hline $\begin{array}{l}\text { 1. Informações em Nível Interno do } \\
\text { País Exportador }\end{array}$ & $\begin{array}{l}\checkmark \text { Legislação de Exportação } \\
\checkmark \text { Acordos bilaterais ou multilaterais assinados } \\
\text { pelo país } \\
\checkmark \text { Feiras de caráter internacional } \\
\checkmark \text { Concorrência }\end{array}$ \\
\hline $\begin{array}{l}\text { 2. Informações sobre o Mercado } \\
\text { Internacional }\end{array}$ & $\begin{array}{l}\checkmark \text { Conjuntura Internacional } \\
\checkmark \text { Fluxos de Comércio e Tendências } \\
\checkmark \text { Acordos internacionais } \\
\checkmark \text { Variação Cambial das principais moedas } \\
\checkmark \text { Países mais ativos na promoção de } \\
\quad \text { importações }\end{array}$ \\
\hline $\begin{array}{l}\text { 3. Informações Específicas sobre o } \\
\text { Produto }\end{array}$ & $\begin{array}{l}\checkmark \text { Tendências Internacionais } \\
\checkmark \text { Normas aplicadas } \\
\checkmark \text { Localização de fornecedores de matéria-prima } \\
\text { e componentes. } \\
\checkmark \text { Tecnologia de produção } \\
\checkmark \text { Normas de embalagem } \\
\checkmark \text { Marcas privilegiadas } \\
\checkmark \text { Ciclo de vida do produto } \\
\end{array}$ \\
\hline $\begin{array}{l}\text { 4. Informações } \\
\text { Selecionado }\end{array}$ & $\begin{array}{l}\checkmark \text { Tendência do mercado } \\
\checkmark \text { Produtos mais comercializados } \\
\checkmark \text { Sistema de distribuição } \\
\checkmark \text { Legislação de importações } \\
\checkmark \text { Concorrência } \\
\checkmark \text { Estrutura de custos logísticos } \\
\checkmark \text { Níveis de preços } \\
\checkmark \text { Entidades reguladoras do comércio exterior } \\
\checkmark \text { Dados geográficos, econômicos, sociais e } \\
\checkmark \text { políticos. } \\
\checkmark \text { Meios de comunicação } \\
\checkmark \text { Laridade cambial } \\
\checkmark \text { Normas técnicas aplicadas }\end{array}$ \\
\hline
\end{tabular}

Fonte: Minervini, 2005

Minervini (2005) cita que muitas informações internas da empresa podem estar descentralizadas, e podem faltar critérios para um fluxo de informações eficientes. O Quadro 8 mostra que a sumarização das informações em grupos distintos pode facilitar o uso e a manipulação dos dados entre os setores envolvidos com a busca e o armazenamento das informações. 
Bradshaw e Burridge (2001) pesquisaram pequenas e médias empresas exportadoras localizadas no Reino Unido que exportaram no período 1996-1998. Os autores relacionaram os tipos de informação requerida para tomada de decisão e as fontes de informação, concluindo que as informações consideradas mais importantes pelas pequenas e médias empresas exportadoras, com citação acima de $80 \%$ das empresas, estão relacionadas com a concorrência internacional e o tamanho do mercado. Como fonte de informação, a pesquisa apontou que as PMEs exportadoras utilizam um sistema próprio para obtenção das informações (72,3\% dos respondentes).

Wood e Robertson (2000) pesquisaram estudos publicados entre 1966 e 1998 que abordaram informações sobre mercados internacionais. A revisão bibliográfica permitiu um levantamento de 200 indicadores considerados relevantes para o investimento internacional. Esses indicadores foram apresentados a um grupo de 16 empresas fornecedoras de informação (bancos, agências do governo e instituições de apoio à exportação) e os resultados obtidos permitiram sintetizar os indicadores em dimensões políticas, econômicas, culturais, legais, potencial de mercado e infra-estrutura dos países alvo.

Rickey e Myers (2001) pesquisaram os fatores estratégicos, organizacionais e ambientais que influenciam o uso da informação de mercado nos canais de decisão de exportação, comparando com o desempenho das exportações. A pesquisa foi realizada nos Estados Unidos com 404 empresas exportadoras, cujo volume de exportação ultrapassou 20\% das vendas totais. Os resultados mostraram que o desempenho das exportações está positivamente relacionado com o uso das informações da concorrência, preço do mercado, canais de distribuição, custos e eficiência logística. 
Carvalho (1997) realizou um estudo empírico com 136 empresas brasileiras exportadoras, em 1992, buscando avaliar a importância percebida das informações e suas fontes nos canais de decisão de exportação. Os resultados mostraram que as empresas consideram os preços dos concorrentes, custos de distribuição e o potencial de compra nos países alvo como mais importantes, citados por $90 \%$ das empresas pesquisadas. Como fonte de informação, 97,2\% das empresas citou as viagens pessoais de negócio nos países alvo, e esta fonte é a única correlação positiva com o desempenho das exportações. O estudo não discrimina o tamanho da empresa, ramo de atividade e países alvo.

Os estudos empíricos sobre informação de mercado para os negócios internacionais vêm sendo realizados desde a década de 1970, em vários países (RUIZ, 2005). Mas, estes estudos têm como base os exportadores de países desenvolvidos e não discriminam as empresas por tamanho ou por mercado alvo.

Com base no que foi apresentado nos itens anteriores, será possível elaborar uma pesquisa para investigar se as informações consideradas relevantes são utilizadas pelas empresas brasileiras exportadoras.

O Quadro 9 resume os principais estudos realizados e a categoria de informações relevantes para compor um sistema de inteligência de mercados internacionais. 
Quadro 9: Informações teoricamente relevantes para as atividades internacionais

\begin{tabular}{|c|c|}
\hline Ambiente Sócio Cultural & $\begin{array}{l}\text { Wood e Robertson (2000), Hill (2005), Keegan (2005), Dowle \& } \\
\text { Lowe (2004), Carvalho (1997), Minervini (2005) }\end{array}$ \\
\hline Ambiente Econômico & $\begin{array}{l}\text { Bradshaw e Burridge( 2001). Wood e Robertson (2000), Hill (2005), } \\
\text { Keegan (2005), Dowle \& Lowe (2004), Carvalho(2003), Minervini } \\
(2005)\end{array}$ \\
\hline $\begin{array}{l}\text { Ambiente Político, Legal e } \\
\text { Regulatório }\end{array}$ & $\begin{array}{l}\text { Hill (2005), Keegan (2005), Dowle \& Lowe (2004), Bradshaw e } \\
\text { Burridge( 2001) Wood e Robertson (2000), Carvalho (1997), } \\
\text { Minervini (2005). }\end{array}$ \\
\hline Ambiente Tecnológico & Hill (2005), Keegan (2005), Dowle \& Lowe (2004) \\
\hline Barreiras & $\begin{array}{l}\text { Bradshaw e Burridge( 2001), Wood e Robertson (2000), Carvalho } \\
\text { (1997), Minervini (2005) }\end{array}$ \\
\hline Benefício Fiscal no país alvo & Carvalho (1997), Minervini (2005) \\
\hline Canais de Distribuição & $\begin{array}{l}\text { Carvalho(2003), Hill (2005), Carvalho (1997), Rickey e Myers } \\
\text { (2001), Minervini (2005) }\end{array}$ \\
\hline $\begin{array}{l}\text { Capacidade de Pagamento dos } \\
\text { compradores }\end{array}$ & 7) \\
\hline Concorrência Internacional & $\begin{array}{l}\text { Bradshaw e Burridge( 2001), Wood e Robertson (2000), Hill (2005), } \\
\text { Minervini (2005) }\end{array}$ \\
\hline Concorrência local & $\begin{array}{l}\text { Bradshaw e Burridge( 2001), Wood e Robertson (2000) } \\
\text { Carvalho(2003), Carvalho (1997), Rickey e Myers (2001), } \\
\text { Minervini (2005) }\end{array}$ \\
\hline Crescimento do Mercado & $\begin{array}{l}\text { Bradshaw e Burridge( 2001), Wood e Robertson (2000) } \\
\text { Carvalho(2003), Carvalho (1997) }\end{array}$ \\
\hline $\begin{array}{l}\text { Custos e eficiência logística no } \\
\text { mercado alvo }\end{array}$ & Carvalho (1997), Rickey e Myers (2001), Minervini (2005) \\
\hline Demanda & Keegan (2005), Carvalho (2003), Hill (2005), Carvalho (1997) \\
\hline Infraestrutura de Transporte & Bradshaw e Burridge( 2001), Hill (2005), Carvalho (1997) \\
\hline Preço do Mercado & $\begin{array}{l}\text { Bradshaw e Burridge( 2001), Wood e Robertson (2000), Hill (2005), } \\
\text { Carvalho (1997), Rickey e Myers (2001), Minervini (2005) }\end{array}$ \\
\hline Preferência do Consumidor & Bradshaw e Burridge( 2001), Carvalho(2003), Carvalho (1997) \\
\hline Produtos dos concorrentes & $\begin{array}{l}\text { Bradshaw e Burridge( 2001), Wood e Robertson (2000), Hill (2005), } \\
\text { Carvalho (1997), Rickey e Myers (2001), Minervini (2005) }\end{array}$ \\
\hline Tamanho do Mercado & $\begin{array}{l}\text { Bradshaw e Burridge( 2001), Wood e Robertson (2000), Carvalho } \\
\text { (1997), Minervini (2005) }\end{array}$ \\
\hline
\end{tabular}

Fonte: Organizado pela autora a partir das fontes citadas. 
As informações citadas no Quadro 9 compõem a base de pesquisa para investigar o uso das informações, consideradas relevantes, pelas empresas exportadoras para atuação no mercado internacional. 


\section{Aspectos Metodológicos}

\subsection{Introdução}

Este capítulo objetiva descrever a metodologia utilizada na pesquisa. Marconi \& Lakatos (2005) descrevem que o método é o conjunto das atividades que permitem alcançar um objetivo - conhecimentos válidos e verdadeiros - de forma a tracejar o caminho a ser seguido, verificação dos erros e auxiliando as decisões do pesquisador.

As pesquisas de campo dividem-se em três grandes grupos: quantitativo-descritivos, exploratórios e experimentais (TRIPOLDI et. al, 1975). Os estudos quantitativo-descritivos são investigações empíricas e cuja finalidade principal é a análise das características dos fatos ou fenômenos e podem ser realizadas por estudos descritivos da população para descrever suas características, contendo um grande número de variáveis, utilizado técnicas de amostragem com caráter representativo. Os estudos exploratórios são investigações com o objetivo de formulação de questões e os experimentais objetivam o teste de hipóteses (MARCONI \& LAKATOS, 2005).

Este trabalho objetiva levantar características de um grupo e, segundo Marconi \& Lakatos (2005), os dados podem ser obtidos por meio de pesquisa de campo, cujo objetivo é conseguir informações e/ou conhecimento acerca de um problema, para o qual se procura uma resposta, ou ainda, descobrir novos fenômenos e suas relações.

Pela natureza dos objetivos deste trabalho, esta pesquisa não formula hipóteses que demandem testes estatísticos para rejeita-las ou não. A descrição e operacionalização do método, instrumentos de coleta, tratamento dos dados e as limitações estão descritas a seguir. 


\subsection{Descrição do Método}

Para que os resultados fossem alcançados, este trabalho foi realizado em seis etapas, que estão descritas a seguir:

\section{Etapa 1: Revisão Bibliográfica}

Esta etapa consistiu na análise da literatura nacional e internacional, com o propósito de identificar os principais estudos já realizados sobre o uso de informações para atuação no mercado internacional. Observou-se que a maioria dos estudos foi realizada por autores internacionais, com raras publicações e estudos realizados no Brasil. O estudo bibliográfico permitiu a delimitação do tema, buscando também a definição do método de pesquisa para se chegar ao objetivo proposto.

\section{Etapa 2: Delimitação do estudo de campo}

Nesta etapa ficou definido, tanto pelo caráter das pesquisas já realizadas como pelo desejo da pesquisadora, que os resultados poderiam ser mais bem visualizados por meio de um estudo de campo com empresas exportadoras. Em função do grande volume de empresas brasileiras exportadoras e da exigüidade do tempo, optou-se por selecionar as empresas do estado de São Paulo e posteriormente reduzir o plano amostral para Ribeirão Preto e municípios circunvizinhos: Altinópolis, Batatais, Brodowski, Cravinhos, Serrana e Sertãozinho. 


\section{Etapa 3: Elaboração do Questionário}

Segundo Marconi \& Lakatos (2005, p.204), ao se elaborar um questionário, algumas normas devem ser observadas a fim de se aumentar sua eficácia e validade, considerando os grupos de perguntas, a ordem e a formulação das questões, que devem ser limitadas em extensão e finalidade. A revisão bibliográfica permitiu identificar que algumas variáveis foram abordadas pelos pesquisadores e poderiam causar dificuldade para os respondentes, além da extensão do questionário final. Para identificar possíveis falhas no questionário e para que atingisse os objetivos propostos, optou-se pela realização de um pré-teste.

\section{Etapa 4: Pré-Teste}

Marconi \& Lakatos (2005, p. 205) citam que o questionário precisa ser testado antes da utilização definitiva, aplicando-o em uma pequena população escolhida. Para a seleção dessa população, optou-se por dividir a amostra em empresas exportadoras industriais e comerciais, selecionando as empresas comerciais exportadoras para a realização do pré-teste. Esta etapa foi realizada com entrevistas pessoais e permitiu a correção de falhas no questionário inicial, excluindo alguns itens e modificando a redação de outros, bem como a medição do tempo de resposta, de forma a estimular a resposta.

\section{Etapa 5: Coleta de Dados de Campo}

Esta etapa foi realizada com as empresas exportadoras industriais, que foram contatadas por telefone, convidando-as a participar da pesquisa, bem como esclarecendo os objetivos da pesquisa. O questionário foi enviado por e-mail, diretamente para o setor de exportação, 
identificado no contato telefônico inicial. Depois de decorrida uma semana, as empresas, que ainda não haviam respondido o questionário, foram contatadas novamente para confirmar o recebimento do email e solicitar o retorno das respostas. Aguardou-se mais uma semana para o encerramento da coleta de dados.

\section{Etapa 6: Análise dos dados de campo}

Nesta etapa os dados foram analisados e tabulados para a análise das respostas, permitindo o tratamento dos resultados práticos com o levantamento bibliográfico realizado. Estas etapas podem ser visualizadas na Figura que se segue:

Figura 6: Etapas da Pesquisa
$\underline{\text { Etapa } 1}$
Revisão
Bibliográfica

$\square \sqrt{\begin{array}{l}\text { Delimitação } 2 \\ \text { do Estudo de } \\ \text { Campo }\end{array}}$

$\bigsqcup$\begin{tabular}{c}
$\begin{array}{c}\text { Elaboração do } 3 \\
\text { Questionário }\end{array}$ \\
\hline
\end{tabular}
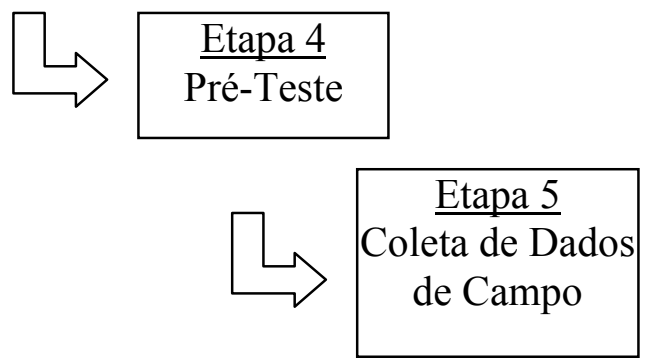

$\longrightarrow \quad \begin{gathered}\frac{\text { Etapa } 6}{\text { Análise dos }} \\ \text { dados }\end{gathered}$




\subsection{Operacionalização do Método de Pesquisa}

Este item detalha a metodologia utilizada para que as etapas descritas na seção anterior fossem concluídas.

\subsubsection{Etapa 1: Revisão Bibliográfica}

Nesta etapa, foram realizadas exaustivas buscas de artigos e obras publicadas sobre o tema de pesquisa, baseando-se no foco principal que é o uso de informações para atuação no mercado internacional. Buscaram-se inicialmente os principais autores que abordaram os temas em livros, e que caracterizassem uma teorização do assunto. Observou-se que o tema estava abordado por autores que focavam teoria econômica e, no âmbito do estudo da administração, literatura relacionada a marketing internacional, optando-se por revisar os dois focos de estudo e aprofundando nos artigos publicados em periódicos, tendo como tema de busca marketing internacional.

Foram localizados artigos publicados nas duas últimas décadas, nos principais periódicos internacionais. Como já foi descrito na seção anterior, a maioria dos artigos encontrados foi publicada por autores estrangeiros, sendo que alguns trabalhos publicados no Brasil relacionavam-se a aplicação de estudos internacionais no mercado brasileiro (MARCERA \& URDAN, 2002; CABRAL \& SILVA JR, 2004; SILVA \& ROCHA, 2001; MACHADO, 2005; ARBIX et al., 2005; HEMAIS et al., 2004; CARVALHO, 1999).

Além dos artigos pesquisados, foram localizadas publicações do governo brasileiro (BNDES e SEBRAE) em estudos para caracterização da base exportadora e que foram 
utilizados neste trabalho, visando a caracterização da base de dados e delimitação do tema de pesquisa (PUGA, 2000; VEIGA, 2002; MARKWALD e PUGA, 2002; GUIMARÃES, 2002; SEBRAE (1998 e 2005).

Com a finalização do levantamento bibliográfico, foram elaboradas análises para a descrição da revisão da literatura, de forma a caracterizar a pergunta de pesquisa e a definição da metodologia utilizada para atingir o objetivo proposto. A seção a seguir descreve a delimitação do estudo de campo.

\subsection{2. - Etapa 2: Delimitação do Estudo de Campo}

O estudo de campo ficou definido depois da revisão bibliográfica. Observou-se que, tanto no Brasil quanto no exterior e nos estudos do governo brasileiro, foram realizadas pesquisas com empresas exportadoras. Além disso, por ser um propósito da conclusão do trabalho da pesquisadora, bem como, ao delimitar o tema, observou-se que não havia pesquisa realizada no Brasil com este tema específico: uso de informações de mercado.

Para identificação das empresas brasileiras exportadoras, foi utilizado o Relatório de Empresas Exportadoras elaborado pelo DEPLA/SECEX, do Ministério do Desenvolvimento, ano base 2005, divulgado no Relatório Exportação Brasileira - Distribuição por porte de empresa, reproduzido na Tabela 10. 
Tabela 10: Exportação Brasileira - Distribuição por porte de empresa

\begin{tabular}{|c|c|c|c|c|c|c|c|c|}
\hline \multicolumn{9}{|c|}{2005 (Jan-Dez) } \\
\hline & \multicolumn{2}{|c|}{ TOTAL ANUAL } & \multicolumn{2}{|c|}{ INDÚSTRIA } & \multicolumn{2}{|c|}{ COMÉRCIO/SERVIÇOS } & \multicolumn{2}{|c|}{ OUTROS } \\
\hline & $\begin{array}{c}\mathbf{N}^{\mathbf{o}} \\
\text { Empr } \\
\end{array}$ & $\begin{array}{c}\text { Valor US\$ } \\
\text { FOB mil } \\
\end{array}$ & $\begin{array}{c}\mathbf{N}^{\mathbf{o}} \\
\text { Empr } \\
\end{array}$ & $\begin{array}{c}\text { Valor US\$ } \\
\text { FOB mil } \\
\end{array}$ & $\mathbf{N}^{\circ}$ Empr & $\begin{array}{c}\text { Valor US\$ } \\
\text { FOB mil } \\
\end{array}$ & $\begin{array}{c}\mathbf{N}^{\circ} \\
\text { Empr }\end{array}$ & $\begin{array}{c}\text { Valor } \\
\text { US\$ } \\
\text { FOB mil }\end{array}$ \\
\hline Total Geral & 19.992 & 118.308 .269 & 13.898 & 96.006 .439 & 5.548 & 22.085 .049 & 546 & 216.781 \\
\hline Micro & 3.832 & 238.732 & 1.882 & 137.771 & 1950 & 100.960 & 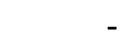 & - \\
\hline Pequena & 5.318 & 1.911 .926 & 3.441 & 1.234 .475 & 1.877 & 677.450 & - & - \\
\hline Média & 5.645 & 7.995 .318 & 4.907 & 6.881 .797 & 738 & 1.113 .521 & - & - \\
\hline Grande & 4.651 & 107.945 .512 & 3.668 & 87.752 .395 & 983 & 20.193 .117 & - & - \\
\hline Pessoa & & & & & & & & \\
\hline Física & 546 & 216.781 & - & - & - & - & 546 & 216.781 \\
\hline
\end{tabular}

Fonte: Ministério do Desenvolvimento, 2006

De acordo com a Tabela 10, 19.992 empresas exportaram no ano de 2005, sendo que $69,5 \%$ eram indústrias e 30,5\%, comércio e serviços. Buscou-se nesta delimitação, identificar a distribuição das empresas por Unidade da Federação, utilizando o relatório Exportação Brasileira por porte de empresa, distribuídas por Unidade da Federação dos exportadores. Com base neste Relatório foi possível construir a Tabela 11 para verificar a representatividade do estado de São Paulo no volume exportado.

Tabela 11: Representatividade das empresas exportadoras de São Paulo

\begin{tabular}{||l||c||c|c||}
\hline Quantidade de empresas & $\begin{array}{c}\text { Empresas Exportadoras } \\
\mathbf{2 0 0 5}\end{array}$ & $\begin{array}{c}\text { Localização: } \\
\text { São Paulo }\end{array}$ & Representatividade \\
\hline \hline Total Geral & 19.992 & 7.941 & $39,7 \%$ \\
\hline Micro Empresa & 3.832 & 1.363 & $35,6 \%$ \\
\hline Pequena Empresa & 5.318 & 2.176 & $40,9 \%$ \\
\hline Media Empresa & 5.645 & 2.436 & $43,1 \%$ \\
\hline Grande Empresa & 4.651 & 1.820 & $39,1 \%$ \\
\hline Pessoas Físicas & 546 & 146 & $26,7 \%$ \\
\hline \hline
\end{tabular}

Fonte: Ministério do Desenvolvimento, 2006.

A elaboração da Tabela 11 permitiu a definição do estado de São Paulo como foco da pesquisa considerando que as empresas paulistas têm uma participação significativa no 
volume exportado pelo país, respondendo por 39,7\% deste total. Com base neste percentual, optou-se por selecionar as empresas exportadoras situadas no estado de São Paulo, tanto pela relevância, quanto pela conveniência. Porém, a coleta de dados deste universo (7.941 empresas) seria inviável pelo tempo e recursos disponíveis para pesquisa. Para a viabilização da pesquisa, optou-se por selecionar as empresas localizadas em Ribeirão Preto. Tendo em vista que a amostra resultou em 79 empresas, optou-se por expandir a pesquisa para as cidades circunvizinhas Altinópolis, Batatais, Brodowski, Cravinhos, Serrana e Sertãozinho, de forma a aumentar a base de dados, totalizando 134 empresas.

A Figura 7 apresenta um esquema das etapas para a seleção da amostra.

Figura 7: Etapas para seleção da amostra

\begin{tabular}{|c|c|c|}
\hline $\begin{array}{c}19.992 \\
\text { Empresas } \\
\text { Brasileiras } \\
\text { Exportadoras } \\
2005\end{array}$ & $\begin{array}{c}1341 \\
\text { Empresas } \\
\text { localizadas } \\
\text { em São Paulo }\end{array}$
\end{tabular} \mid $\begin{gathered}134 \\
\text { Empresas localizadas na região de } \\
\text { Ribeirão Preto } \\
\text { (Rib. Preto, Altinópolis, Batatais, } \\
\text { Brodowski, Cravinhos, Serrana e } \\
\text { Sertãozinho) }\end{gathered}$

A representatividade das empresas exportadoras definidas para o estudo de campo pode ser visualizada na Tabela 12 e Gráfico 6.

Tabela 12: Plano Amostral

\begin{tabular}{|l|c||}
\hline Cidade & Empresas Exportadoras \\
\hline Ribeirão Preto & 79 \\
\hline Altinópolis & 1 \\
\hline Batatais & 7 \\
\hline Brodowski & 2 \\
\hline Cravinhos & 11 \\
\hline Serrana & 2 \\
\hline Sertãozinho & 32 \\
\hline TOTAL & 134 \\
\hline
\end{tabular}


Gráfico 6: Representatividade Amostral

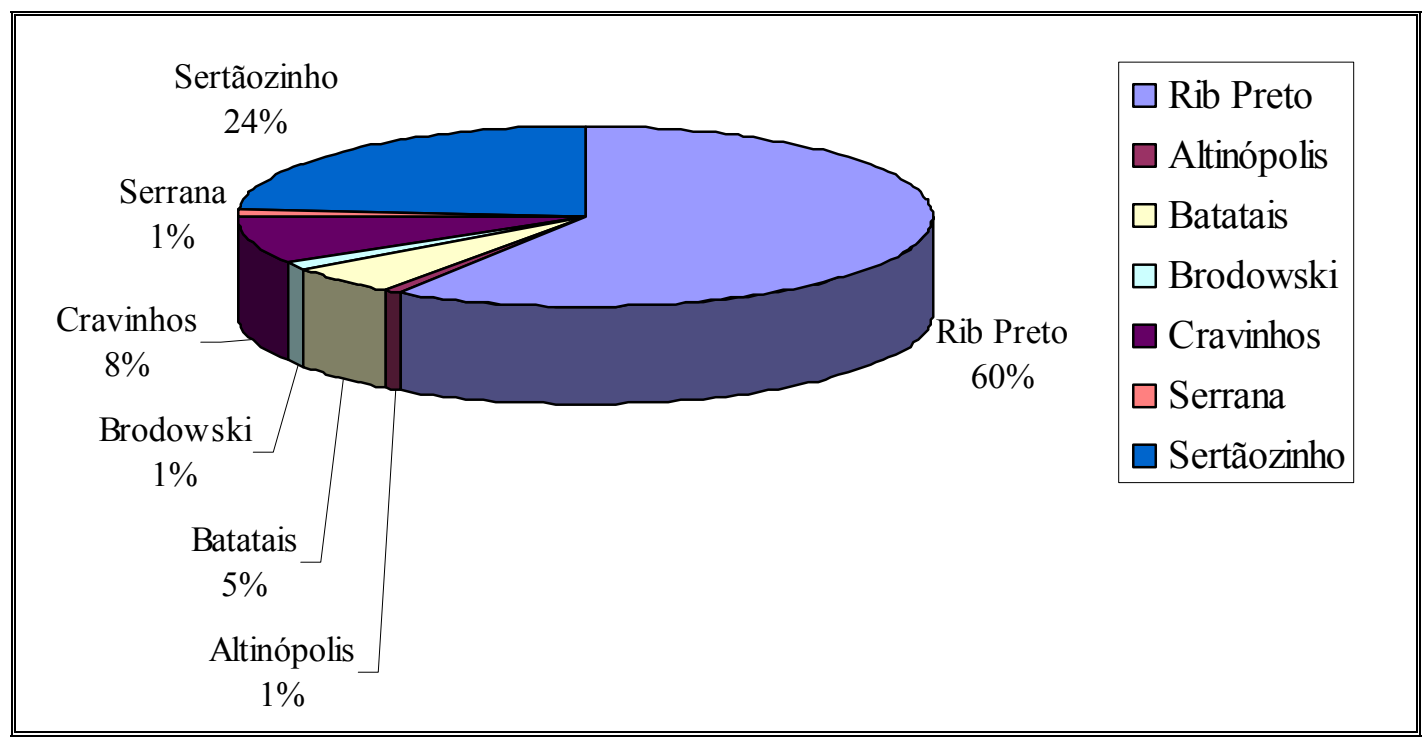

\subsection{3. - Etapa 3: Elaboração do Questionário}

A partir da revisão bibliográfica, foram identificadas, conforme descrito no Capítulo 2 , algumas variáveis definidas por pesquisadores, em estudos de campo, para identificar as informações citadas como relevantes.

Richardson (1999) cita que o questionário cumpre duas funções: descrever as características e medir determinadas variáveis, sendo responsabilidade do pesquisador determinar o tamanho, a natureza e o conteúdo do questionário, de acordo com o problema pesquisado e de respeitar o entrevistado como ser humano.

Segundo Richardson (1999), a utilização de questionários tem vantagens e desvantagens. As vantagens são:

1. Permite obter informações de um grande número de pessoas simultaneamente ou em um tempo relativamente curto. 
2. Permite abranger uma área geográfica ampla, sem ter necessidade de um treinamento demorado dos aplicadores dos questionários.

3. Apresenta uma relativa uniformidade de medição.

4. No caso de anonimato as pessoas podem se sentir com maior liberdade de expressar suas opiniões.

5. O fato de ter tempo suficiente para responder ao questionário pode proporcionar respostas mais refletidas que as obtidas em uma primeira aproximação com o tema pesquisado.

6. A tabulação de dados pode ser feita com maior facilidade e rapidez que outros instrumentos.

As desvantagens, citadas por Richardson (1999), são:

1. Muitas vezes não se obtêm os $100 \%$ de respostas aos questionários, podendo-se produzir vieses na amostra, que afetam a representatividade dos resultados.

2. Problema de validade. Nem sempre é possível ter certeza de que a informação proporcionada pelos entrevistados corresponde à realidade. Isso varia segundo o tema tratado.

3. Problema de confiabilidade. As respostas dos indivíduos variam em diferentes períodos de tempo.

Marconi \& Lakatos (2005), ao abordar o processo de elaboração do questionário, citam que a seleção de questões deve ser cuidadosa, levando-se em consideração a importância e, se oferece condições de obtenção de informações válidas. Além disso, é importante considerar a complexidade e o tempo que o respondente vai utilizar, para que não se torne cansativo e desinteressante, cujo resultado pode invialibizar a pesquisa. 
Considerando as orientações dos autores (RICHARDSON, 1999 e MARCONI \& LAKATOS, 2005) e a base do referencial bibliográfico foi elaborado o questionário inicial, contendo as variáveis, objeto deste projeto, para investigar as informações sobre mercados internacionais que compõem o sistema de inteligência de mercados internacionais aplicado à atuação das empresas exportadoras.

\subsubsection{Apresentação das Variáveis}

Segundo Marconi \& Lakatos (2005), uma variável pode ser considerada como um conceito operacional ou fator discernível em um objeto de estudo, passível de mensuração. As variáveis objeto do estudo devem, segundo Marconi \& Lakatos (2005), ser definidas com clareza e objetividade e de forma operacional. Este procedimento visa controlar a pesquisa de forma a impedir o comprometimento ou invalidação dos dados coletados.

As variáveis utilizadas nesta pesquisa foram baseadas e adaptadas de outros questionários identificados na revisão bibliográfica, resultando no modelo conceitual que está representado a seguir (Figura 8), considerando as variáveis em estudo:

Figura 8 - Modelo Conceitual da Pesquisa

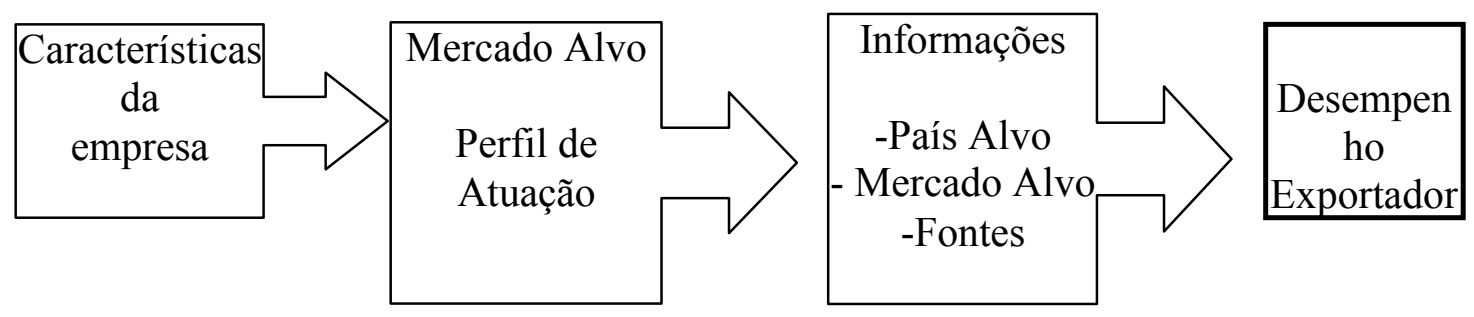




\subsubsection{Etapa 4: Pré-Teste}

Para a realização desta etapa, considerou-se a quantidade de empresas da região (134). Foram identificadas 19 empresas comerciais exportadoras por contato telefônico prévio, convidando-as a participarem do pré-teste do questionário. Das 19 empresas, cinco concordaram em participar, duas foram entrevistadas pessoalmente e as três por telefone.

Os respondentes colaboraram com os seguintes comentários sobre o questionário:

1. Tempo de resposta.

2. Clareza das questões.

3. Inclusão do país China, separadamente da Ásia e inclusão do Oriente Médio.

4. Exclusão de algumas informações, consideradas ambíguas.

5. Separação das informações do país e do mercado para maior clareza das respostas.

6. Agrupamento de dados numéricos, evitando exposição desnecessária da empresa.

As sugestões foram absorvidas resultando na remodelação do questionário, que está explicada no item a seguir e cuja versão final é apresentada na seção “Anexos - Instrumento de Pesquisa." 


\subsubsection{Versão Final do Questionário}

Após o pré-teste, a versão final do questionário foi formatada, utilizando-se uma tabela, na qual o respondente, após a leitura da assertiva, coloca um " $x$ ” na lacuna correspondente.

O Quadro 10 considera as variáveis utilizadas nesta pesquisa e foram divididas em cinco partes. A primeira identifica as características da empresa (questões qualificadoras). A segunda, coleta as informações sobre os mercados de atuação. A terceira, o perfil de atuação da empresa. A quarta, as informações utilizadas para atuação no mercado internacional, que foram subdivididas em informações gerais do país, sobre o mercado alvo e as fontes de informação utilizadas pela empresa. A quinta e última parte considera as informações do respondente.

Quadro 10 Detalhamento do Questionário

\begin{tabular}{|c|c|c|}
\hline \multicolumn{3}{|c|}{ I - CARACTERÍSTICAS DA EMPRESA } \\
\hline & ESPECIFICAÇÃO & Questões \\
\hline A- Dados da Empresa & Perfil da empresa exportadora & Q1 a Q7 \\
\hline B- Mercados de Atuação & Mercados para os quais a empresa exporta & Q8 a Q14 \\
\hline C- Perfil de Atuação & Como a empresa atua no mercado internacional & Q15 a Q20 \\
\hline \multicolumn{3}{|c|}{ II - INFORMAÇÕES GERAIS } \\
\hline & ESPECIFICAÇÃO & Questões \\
\hline Informações & Informações sobre o mercado alvo & Q21 a Q31 \\
\hline \multicolumn{3}{|c|}{ III - INFORMAÇÕES DE MERCADO } \\
\hline & ESPECIFICAÇÃO & Questões \\
\hline Informações & Mercado de Atuação da Empresa & Q32 a Q42 \\
\hline \multicolumn{3}{|c|}{ IV - FONTES DE INFORMAÇÃO } \\
\hline & ESPECIFICAÇÃO & Questões \\
\hline Fontes de Informação & Onde a empresa busca as informações & Q43 a Q51 \\
\hline \multicolumn{3}{|c|}{ V - PERFIL DO RESPONDENTE } \\
\hline & ESPECIFICAÇÃO & Questões \\
\hline Dados do Respondente & Informações sobre o respondente do questionário & Q52 a Q56 \\
\hline
\end{tabular}

As variáveis em estudo são detalhadas a seguir. 
Quadro 11: I-A Características da Empresa

\begin{tabular}{|c|c|c|}
\hline & QQUESTÕES & UTILIZAÇÃO \\
\hline Q1 & Ano de Fundação & \multirow{7}{*}{$\begin{array}{c}\text { Capta as características das empresas } \\
\text { exportadoras }\end{array}$} \\
\hline Q2 & Setor de Atividade da empresa & \\
\hline Q3 & Número de Empregados & \\
\hline Q4 & Receita Anual com Exportações & \\
\hline Q5 & $\begin{array}{l}\text { Participação das Exportações no Volume de } \\
\text { Vendas }\end{array}$ & \\
\hline Q6 & Início das atividades de Exportação - data & \\
\hline Q7 & Primeira exportação - país & \\
\hline
\end{tabular}

O Quadro 11 apresenta detalhadamente as questões formuladas na primeira parte do questionário. As informações obtidas são fundamentais para caracterizar as empresas respondentes e o cruzamento das informações de todos os questionários, permitindo a comparação das respostas com o perfil da empresa. Também é importante para avaliar o perfil da região investigada. As questões quantitativas (Q3, Q4 e Q5) foram apresentadas em agrupamentos, seguindo orientação dos respondentes no pré-teste, evitando que a empresa considerasse uma exposição de dados considerados confidenciais. As demais questões foram abertas para o respondente.

Quadro 12: I-B Mercados de Atuação

\begin{tabular}{|c|l|c||}
\hline \multicolumn{2}{|c|}{ QUESTÕES } & UTILIZAÇ̃̃O \\
\hline \hline Q8 & $\begin{array}{l}\text { MERCOSUL - Argentina, Uruguai e } \\
\text { Paraguai. }\end{array}$ & \\
\hline Q9 & $\begin{array}{l}\text { ALADI - Demais Países latino- } \\
\text { americanos. }\end{array}$ & Capta os países que a empresa opera, agrupados \\
\hline Q10 & UNIÃO EUROPÉIA & por regiões. \\
\hline Q11 & EUA + CANADÁ & \\
\hline Q12 & CHINA & \\
\hline Q13 & Demais países Asiáticos & \\
\hline Q14 & ÁFRICA & \\
\hline Q13 & ORIENTE MÉDIO & \\
\hline Q14 & Demais Países & \\
\hline
\end{tabular}

O Quadro 12 contém os principais mercados de atuação das empresas brasileiras, levantado nas pesquisas divulgadas pelo governo brasileiro. Além da citação das principais 
regiões, os desdobramentos dos continentes americano, africano e asiático seguiram as sugestões das empresas que participaram do pré-teste. Levou-se em consideração que estes mercados estão em expansão para os negócios internacionais brasileiros. A escolha dos mercados de atuação não é excludente, permitindo ao respondente mais de uma resposta.

Quadro 13: I-C - Perfil de Atuação

\begin{tabular}{|c|c|c|}
\hline \multicolumn{2}{|r|}{ QUESTÕES } & UTILIZAÇÃO \\
\hline Q15 & Exportação Direta & \multirow{4}{*}{ Capta a forma de atuação na atividade exportadora } \\
\hline Q16 & Exportação para Distribuidores Próprios & \\
\hline Q17 & $\begin{array}{l}\text { Utilização de Agentes independentes no } \\
\text { mercado alvo }\end{array}$ & \\
\hline Q18 & Utiliza " Exporta Fácil" & \\
\hline Q19 & $\begin{array}{l}\text { A empresa busca constantemente novos } \\
\text { mercados }\end{array}$ & \multirow{2}{*}{$\begin{array}{c}\text { Capta o perfil ativo/passivo na atividade } \\
\text { exportadora }\end{array}$} \\
\hline Q20 & $\begin{array}{l}\text { Não buscamos novos mercados, pois os } \\
\text { clientes nos procuram. }\end{array}$ & \\
\hline
\end{tabular}

O Quadro 13 investiga o perfil de atuação da empresa, de acordo com a revisão da literatura. Além dos perfis sugeridos pelos autores pesquisados, foi acrescentada a questão 18- Utilização do “ Exporta Fácil”, pois trata-se de estratégia utilizadas por empresas brasileiras e que, conforme levantado nas pesquisas de campo do governo brasileiro, foi desenvolvida para o simplificar os procedimentos burocráticos na liberação de mercadorias e com o conseqüente incremento da participação das empresas pequenas e médias empresas brasileiras no cenário internacional. As questões 19 e 20 visam caracterizar, dentro do perfil de atuação, se a empresa é ativa ou passiva na atividade exportadora.

A seguir são apresentados os Quadros 14 e 15 que captam as informações teoricamente relevantes que as empresas utilizam em sua atividade exportadora. 
Marconi \& Lakatos (2005, p. 212) citam que questões em série devem ter a finalidade de aprofundamento e, se colocadas em seguida, ser evitada a distorção das respostas. Levando-se em consideração esta observação, as informações foram divididas em duas baterias. A primeira (Quadro 14) as questões que captam as informações gerais do país e a segunda (Quadro 15), informações do mercado de atuação da empresa.

Quadro 14: II Informações Gerais sobre os países para os quais a empresa exporta

\begin{tabular}{|c|c|c|}
\hline \multicolumn{2}{|r|}{ QUESTÕES } & UTILIZAÇÃO \\
\hline Q21 & Idioma utilizado nas transações internacionais. & \multirow{11}{*}{$\begin{array}{c}\text { Capta as informações gerais sobre o país } \\
\text { alvo }\end{array}$} \\
\hline Q22 & Religião & \\
\hline Q23 & Inflação & \\
\hline Q24 & $\begin{array}{l}\text { Taxa de conversão da moeda do país alvo x dólar } \\
\text { dos EUA }\end{array}$ & \\
\hline Q25 & Renda per Capita & \\
\hline Q26 & Volume de Reservas Internacionais & \\
\hline Q27 & PIB - Produto Interno Bruto & \\
\hline Q28 & Taxa de Desemprego & \\
\hline Q29 & Estabilidade Política & \\
\hline Q30 & Relações Diplomáticas com o Brasil & \\
\hline Q31 & Existência de Acordos Comerciais com o Brasil & \\
\hline
\end{tabular}

O Quadro 14 mostra as questões utilizadas para identificar quais informações gerais sobre o mercado são utilizadas pelas empresas exportadoras. Estas questões foram identificadas na literatura pesquisa na revisão bibliográfica, e após a realização do pré-teste, foram reduzidas e simplificadas para melhor entendimento do respondente. Além dessas considerações, buscou-se um vocabulário que, de forma clara e objetiva, fosse acessível/usual do respondente, para serem entendidas com facilidade. 
Quadro 15: III - Informações sobre o Mercado Alvo

\begin{tabular}{|c|c|c|}
\hline \multicolumn{2}{|r|}{ QUESTÕES } & UTILIZAÇÃO \\
\hline Q32 & Concorrentes Internacionais que atuam no mercado & \multirow{11}{*}{$\begin{array}{c}\text { Capta as informações sobre o } \\
\text { mercado de atuação da } \\
\text { empresa exportadora }\end{array}$} \\
\hline Q33 & $\begin{array}{l}\text { Existência de fabricantes do seu produto no país } \\
\text { alvo }\end{array}$ & \\
\hline Q34 & Estimativa de demanda do seu produto & \\
\hline Q35 & Capacidade de Pagamento dos compradores & \\
\hline Q36 & Preço praticado pelos concorrentes & \\
\hline Q37 & $\begin{array}{l}\text { Incidência de Impostos sobre o seu produto no país } \\
\text { alvo }\end{array}$ & \\
\hline Q38 & $\begin{array}{l}\text { Benefícios Fiscais para o seu produto no mercado } \\
\text { alvo }\end{array}$ & \\
\hline Q39 & Exigências e normas para o seu produto & \\
\hline Q40 & Custos logísticos no país alvo & \\
\hline Q41 & Disponibilidade de transporte para o país alvo & \\
\hline Q42 & $\begin{array}{l}\text { Procedimentos burocráticos para importação do seu } \\
\text { produto no país alvo }\end{array}$ & \\
\hline
\end{tabular}

As informações de mercado (Quadro 15) representaram onze questões citadas como relevantes pela literatura pesquisada e adequadas no pré-teste. Do mesmo modo que as questões do Quadro 12, o vocabulário foi simplificado e adequado para o entendimento do respondente.

As questões que tratam das informações (Quadros 14 e 15) foram dispostas de forma a medir o uso da informação por meio de uma escala de medida Likert (adaptada de 4 pontos) de 0 a 3, variando desde "NÃO USA" até "USA SEMPRE". A escala de somatórios de Likert é, segundo Malhotra (1996), uma escala de pontuação, na qual os respondentes indicam o grau de concordância em relação a uma série de afirmações.

A escala, com seus números e significados, é apresentada no quadro a seguir (Quadro 16). 
Quadro 16: Linha de Resposta do Questionário

\begin{tabular}{|c||c||c||c|c|}
\hline \multirow{4}{*}{ Informações } & 0 & 1 & 2 & 3 \\
\cline { 2 - 5 } & NÃO USA & USA POUCO & USA MUITO & USA SEMPRE \\
\hline \hline Gerais & & & & \\
(Q21-Q31) & & & & \\
\hline Mercado & & & & \\
(Q32-Q42) & & & & \\
\hline
\end{tabular}

O Quadro 16 mostra a disposição das respostas. Para cada informação apresentada a esquerda do questionário, o respondente deveria assinalar com um " $\mathrm{X}$ " na lacuna correspondente. Os valores da escala de Likert não foram apresentados ao respondente.

Quadro 17: IV Fontes de Informação

\begin{tabular}{||c|l||c||}
\hline \multicolumn{2}{|c|}{ QUESTÕES } & UTILIZAÇÃO \\
\hline \hline Q43 & Embaixadas/Consulados Brasileiros & \\
\hline Q44 & Embaixadas/Consulados Estrangeiros & $\begin{array}{c}\text { Capta a utilização de fontes de } \\
\text { informação para atuação no mercado } \\
\text { internacional }\end{array}$ \\
\hline Q45 & Câmaras de Comércio & \\
\hline Q46 & Assinatura de Serviços de Informações & \\
\hline Q47 & Publicações Especializadas & \\
\hline Q48 & A empresa tem um sistema próprio de pesquisa & \\
\hline Q49 & A empresa contrata serviços de pesquisa & \\
\hline Q50 & Feiras Internacionais nos fornecem informações & \\
\hline Q51 & Os clientes nos enviam as informações necessárias & \\
\hline
\end{tabular}

O Quadro 17 mostra as questões apresentadas ao respondente para que este apontasse as fontes de informação utilizadas pela empresa. A quantidade de fontes foi, inicialmente, apontada na bibliografia consultada, acrescida, posteriormente de sugestões das empresas que participaram do pré-teste. As respostas dos itens foram apontadas considerando a escala do Quadro 16. 
Quadro 18: V Informações sobre o Respondente

\begin{tabular}{||c|l|c||}
\hline \multicolumn{2}{|c|}{ QUESTÕES } & UTILIZAÇÃO \\
\hline \hline Q52 & Cargo na Empresa & \\
\hline Q53 & Área de atuação na empresa & $\begin{array}{c}\text { Capta as informações sobre o } \\
\text { respondente do questionário }\end{array}$ \\
\hline Q54 & Formação Educacional & \\
\hline Q55 & Tempo de atuação na área internacional & \\
\hline Q56 & Cursos Específicos na área internacional & \\
\hline
\end{tabular}

O Quadro 18 mostra as questões utilizadas para identificar o perfil do respondente da pesquisa. Estas informações foram utilizadas como critério de eliminação dos questionários. As questões 52 e 53 avaliaram o envolvimento do respondente com os negócios da empresa e as questões 54 a 56, o nível de conhecimento com as questões apresentadas. Como foi realizado o pré-teste com pessoas envolvidas com negócios internacionais, estes observaram que alguns termos utilizados poderiam ser interpretados de forma diferente por funcionários que não tivessem qualificação e conhecimento suficiente para tal.

\subsubsection{Etapa 4 - Coleta de Dados}

A seleção da amostra resultou em 134 empresas, como já foi detalhado na Figura 6. Os dados das empresas foram obtidos no Relatório Exportação Brasileira Por Porte de Empresa, distribuídas por Unidade da Federação dos exportadores, disponibilizado pelo DEPLA/SECEX, do Ministério do Desenvolvimento (2006), que contém os dados das empresas exportadoras tais como: CNPJ, Razão Social e Endereço Completo. Com base nestes dados, foi utilizado primeiramente o catálogo telefônico das cidades para identificar o número do telefone da empresa. Algumas empresas não constavam no catálogo telefônico e alguns números de telefone já haviam sido trocados. Para localizar estas empresas, foi utilizado o sistema de busca disponível na rede mundial de computadores. 
A partir de então, as empresas foram contatadas, diretamente com o setor de exportação para convidar a participar da pesquisa, bem como para informar o endereço de e-mail para o qual deveria ser encaminhado o questionário. Este procedimento foi necessário, principalmente para garantir o retorno da resposta e garantir que a mensagem foi enviada de fonte confiável.

As empresas restantes totalizaram 115. Ao pesquisar o número de telefone, 25 não foram localizadas, sendo que algumas empresas não figuravam no catálogo telefônico, tanto da relação por assinantes quanto por endereço, outras haviam se mudado e as demais, o número do telefone encontrado, ao ser utilizado, não atendeu a chamada. Desta forma, 90 empresas foram contatadas, porém cinco delas se recusaram a receber o questionário com a alegação de que a empresa tinha por norma o não fornecimento de informações sobre sua atuação internacional, restando assim, o envio de 85 emails com a carta convite e o questionário. A Tabela 13 esquematiza esta etapa:

Tabela 13: Amostra Selecionada para Coleta de Dados

\begin{tabular}{||l||l||}
\hline Empresas da Região & 134 \\
\hline \hline (-) Empresas exclusivamente comerciais & $(19)$ \\
\hline = Empresas exportadoras & 115 \\
\hline (-) Não Localizadas & $(25)$ \\
\hline (-) Recusaram a participação & $(5)$ \\
\hline \hline = Envio do questionário & 85 \\
\hline \hline
\end{tabular}


O e-mail convite com o questionário foi enviado para as 85 empresas selecionadas. Durante uma semana, aguardou-se o recebimento das respostas, sendo que 28 empresas responderam espontaneamente. Na semana seguinte, as empresas não respondentes foram contatadas novamente, por telefone, para confirmar o recebimento do e-mail, bem como para perguntar se havia dúvidas no preenchimento ou dificuldades para a resposta. Foi necessário o reenvio do questionário para oito empresas.

Decorrida mais uma semana, a quantidade de respostas recebidas atingiram 46, representando 53\% de retorno dos questionários. De acordo com Marconi \& Lakatos (2005), em média, os questionários expedidos alcançam 25\% de devolução. Considerou-se a amostra relevante para o tratamento dos dados. Os resultados obtidos estão descritos no Capítulo 4 Resultados Empíricos.

A seguir são apresentadas as técnicas de análise dos dados coletados.

\subsubsection{Etapa 5 - Análise dos Dados}

A técnica de análise de dados apropriada, segundo Anderson et.al. (2003), depende dos dados obtidos que podem ser qualitativos ou quantitativos. Os dados quantitativos indicam uma quantidade específica obtida pelo levantamento de dados e os dados qualitativos são obtidos parra identificar um atributo de cada elemento (ANDERSON et. al., 2003).

O método estatístico, segundo Marconi \& Lakatos (2005), fornecer uma descrição quantitativa da sociedade, especificando as suas características que contribuam para seu melhor entendimento e pode ser considerado um método de experimentação e prova, pois é um método de análise. 
Os estudos empíricos podem apontar a aplicabilidade das dimensões teóricas e os grupos analisados podem não refletir as características de uma população (AAKER \& DAY, 1983). O alvo desta pesquisa é um pequeno estrato de empresas exportadoras e o processo amostral não é probabilístico. Estas características colocam, então, os estudos piloto entre uma pesquisa exploratória e descritiva.

Para entender os objetivos deste trabalho, as características do grupo estudado, bem como a quantidade de questões no questionário (56), as técnicas que mais adequadas são a estatística descritiva e análise fatorial, que serão discutidas a seguir.

\subsection{Metodologia de Análise dos Dados}

Esta pesquisa visou levantar características de um grupo por meio de pesquisa de campo, cujo objetivo é, segundo Marconi \& Lakatos (2005), conseguir informações e/ou conhecimento acerca de um problema, para o qual se procura uma resposta, ou ainda, descobrir novos fenômenos e suas relações.

Pela natureza de seus objetivos, a presente pesquisa não formula hipóteses rígidas que necessitem de testes estatísticos para rejeitá-los ou não. Os objetivos centraram na identificação de um grupo de empresas exportadoras, no uso das informações utilizadas pelas empresas atuar no mercado internacional, com avaliação da freqüência de uso por estas empresas. Para atingir estes objetivos, foi utilizada a distribuição por freqüência que, segundo Anderson et al. (2003), é um sumário tabular que mostra a freqüência de observações de cada uma das questões propostas, sendo válida tanto para dados quantitativos quanto para dados 
qualitativos. Com esta técnica é possível quantificar e conhecer as características das empresas exportadoras da região.

Os dados referentes ao uso das informações, objeto desta pesquisa, foram submetidos a análise fatorial, que é aplicada com o objetivo de reduzir as variáveis, agrupando-as em um menor número de fatores. Este procedimento possibilita a identificação das dimensões do estudo, facilitando a análise dos dados (HAIR et al., 2005)

Para a aplicação da análise fatorial, os dados foram submetidos ao teste KMO (Kaiser Meyer Olkin) que possibilita medir a adequacidade da utilização da Análise Fatorial para a base de dados e ao teste de esfericidade de Bartlett que mede se a análise fatorial é adequada ao problema. Este teste verifica se existe correlação suficientemente forte para que a análise fatorial possa ser aplicada.

\subsection{Limitações Metodológicas}

Ainda que se tenha tentado reduzir as limitações e evitar falhas, as pesquisas científicas estão sujeita a elas. Podem ser citadas as seguintes limitações que possam ter ocorrido, sem que a autora pudesse controlá-las:

a) Os respondentes dos questionários podem não ter se empenhado no preenchimento dos questionários.

b) A amostra utilizada com os questionários respondidos, pode não refletir exatamente os dados da população.

c) Os dados foram obtidos de empresas exportadoras localizadas em sete cidades da região de Ribeirão Preto, cujos resultados não podem ser generalizados para empresas 
exclusivamente comerciais ou de serviços, bem como para outras regiões do estado, ou para o restante do país.

d) As respostas foram enviadas por email e retornadas por respondentes que se qualificaram para tal, não tendo a pesquisadora o controle das ações dos respondentes, cujo questionário pode ter sido respondido por pessoa diversa do destinatário.

Os métodos utilizados para análise dos dados refletem a crença da autora de que, baseado nos autores consultados (ANDERSON ET. AL., 2003; MARCONI \& LAKATOS, 2005; LARSON \& FARBER, 2004; HAIR ET. AL. 2005)), foram os melhores caminhos para alcançar os objetivos desta pesquisa. 


\section{Estudos Empíricos}

Esta seção descreve o tratamento dos dados obtidos. Segundo Marconi \& Lakatos (2005), antes de analisar os dados, é necessário alguns passos: seleção, codificação e tabulação dos dados.

Para a seleção dos dados, foi feita uma verificação crítica nos questionários recebidos, para observar se os questionários foram corretamente preenchidos e com dados completos, para evitar que causassem distorções no resultado da pesquisa. A Tabela 14 mostra o resultado da seleção dos questionários.

Tabela 14: Resultado da Seleção dos Questionários

\begin{tabular}{|c|c|c|c|}
\hline \multicolumn{4}{|c|}{ Seleção da Amostra } \\
\hline \multicolumn{2}{|c|}{ Total de Empresas da Região } & 134 & Total \\
\hline$(-)$ & Empresas Comerciais & 19 & Cinco participaram do Pré-Teste \\
\hline$(-)$ & Empresas Não localizadas & 25 & \\
\hline$(-)$ & Recusa na participação & 5 & \\
\hline \multicolumn{2}{|c|}{ Envio do Questionário } & 85 & $100 \%$ \\
\hline \multicolumn{2}{|c|}{ Questionários Recebidos } & 45 & $53 \%$ \\
\hline$(-)$ & Dados Inválidos & 6 & $7 \%$ \\
\hline \multicolumn{2}{|c|}{ Questionários Válidos } & 39 & $46 \%$ \\
\hline
\end{tabular}

Os dados da Tabela 14 mostram como foi feita a seleção dos questionários para tabulação dos dados. Das 134 empresas exportadoras da região, 19 empresas, identificadas 
como exclusivamente comerciais exportadoras, que atuam como intermediárias no processo de exportação, foram selecionadas para participação no pré-teste.

Das empresas exportadoras restantes (115), 25 não foram localizadas, restando 90 empresas, que foram contatadas por telefone e convidadas a participar da pesquisa. Foi solicitado, na ocasião, um endereço de $e$-mail para envio do questionário, diretamente ao responsável pelo setor de exportação. Neste contato, 5 empresas se recusaram a responder o questionário, alegando política da empresa, principalmente com relação à divulgação de informações consideradas confidenciais, resultando no envio de 85 questionários.

No prazo final de duas semanas, 45 questionários retornaram com as respostas. No entanto, foi necessário excluir 6 questionários, por apresentarem problemas com o preenchimento, com falta e/ou inconsistência dos dados. Restaram assim, 39 questionários válidos, considerados como adequados para tabulação e análise dos dados, representando $46 \%$ de retorno.

De acordo com Marconi \& Lakatos (2005), em média, os questionários expedidos alcançam $25 \%$ de devolução. Nesse caso, obteve-se maior índice de retorno, maior que a média relatada na literatura, considerou-se a amostra relevante para o tratamento dos dados.

Os resultados obtidos em campo, após a aplicação dos questionários e tabulação dos dados, estão descritos a seguir. 


\subsection{Dados da Amostra}

\subsubsection{Características da Amostra}

As informações obtidas foram fundamentais para caracterizar as empresas respondentes e entender o perfil das empresas da região. A primeira questão, que investiga o tempo de existência da empresa, mostra que apenas 5,2\% iniciaram suas atividades antes da década de 50 e 47,4\% foram fundadas após 1990. A década de 90 foi quando 31,6\% das empresas pesquisadas iniciaram suas atividades.

Gráfico 7: Ano de Fundação da Empresa

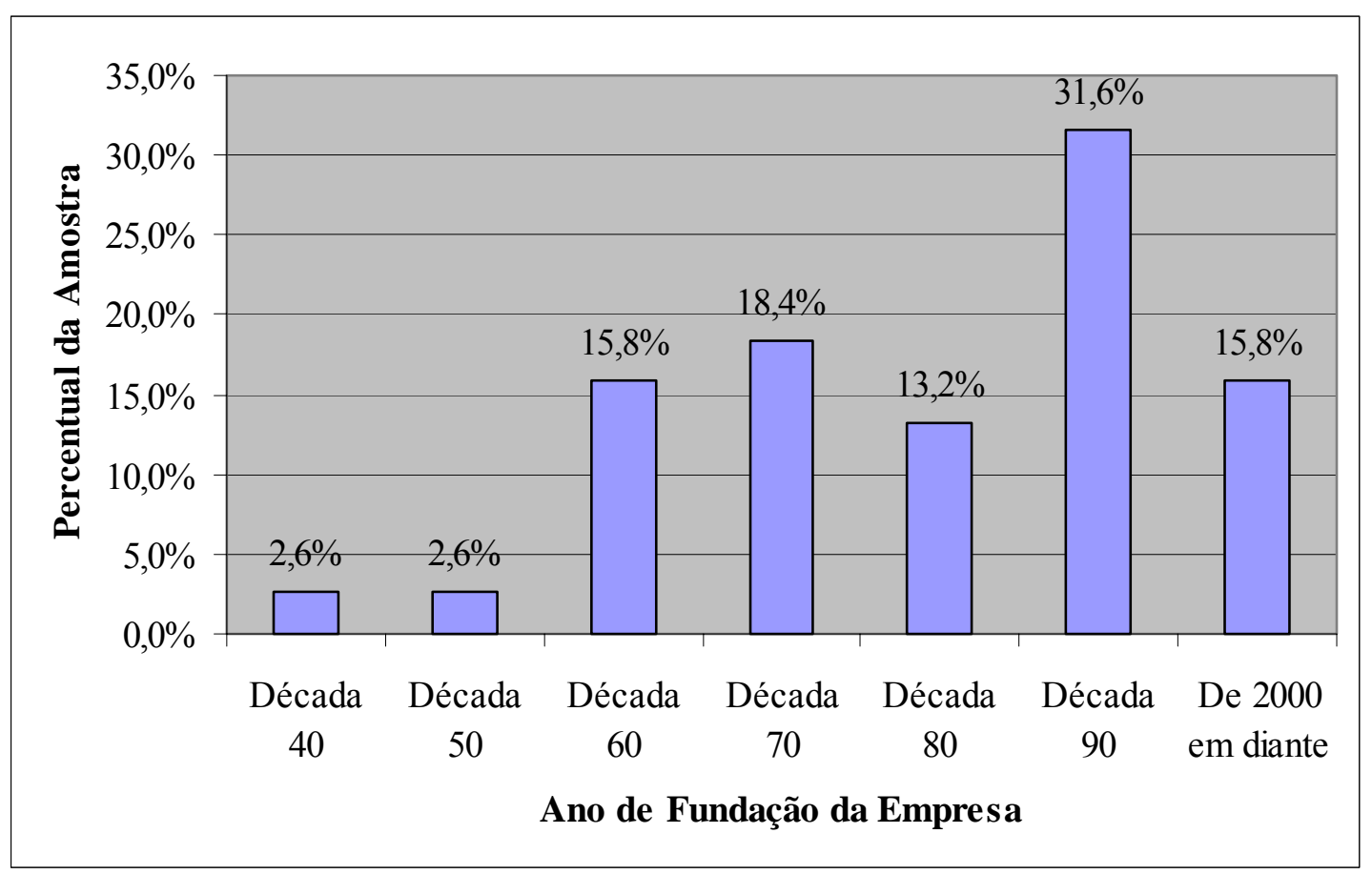

Com relação ao número de empregados (Gráfico 8), o resultado mostra que 42,1\% das empresas possuem de 11 a 40, o que pode ser consideradas empresas de pequeno e médio porte de acordo com a Classificação das Empresas Exportadoras do DEPLA/SECEX do 
Ministério do Desenvolvimento (2006). O resultado também mostra que 28,9\% das empresas exportadoras da região empregam mais de 200 pessoas, consideradas grandes empresas.

Gráfico 8: Número de Funcionários

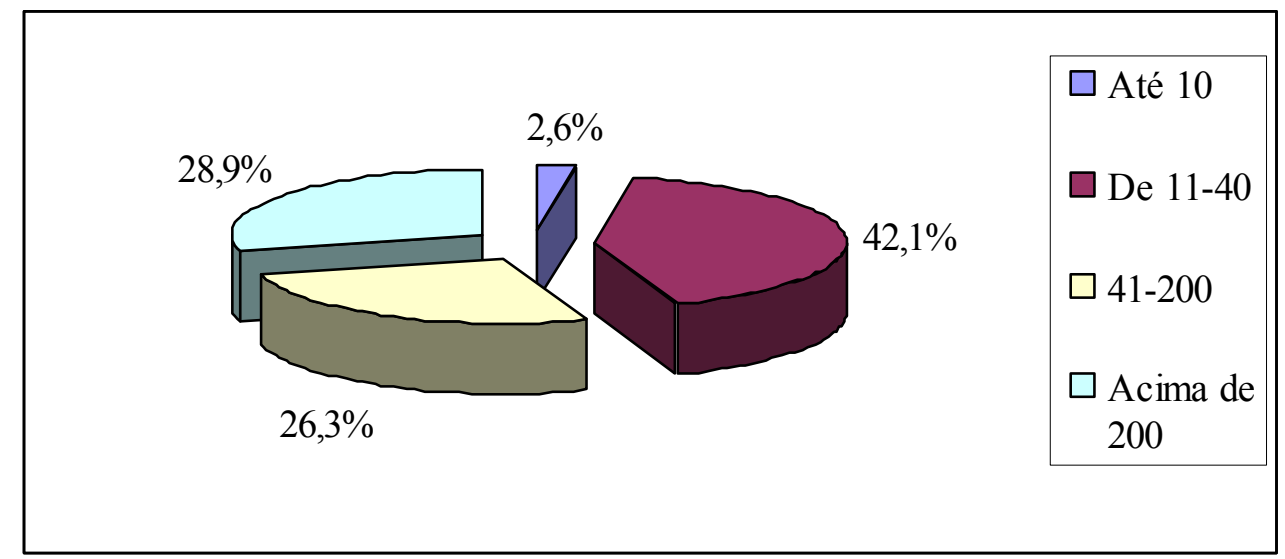

O Gráfico 9 mostra a Receita Anual das empresas exportadoras da região com a exportação. O questionário solicitou a resposta de acordo com uma escala, evitando que houvesse distorção nas informações ou ainda, que a empresa considerasse tais dados confidenciais e se recusasse a fornecê-los. Além disso, a escala utilizada é a fornecida pelo DEPLA/SECEX do Ministério do Desenvolvimento (2006) mostrada na Tabela 2 do Capítulo 1, que mostra a classificação das empresas exportadoras por volume exportado. Nesse caso, optou-se por adotar a classificação industrial.

O resultado mostra que a maior parte das empresas (47,4\%) exporta até US 400 mil anuais, caracterizando o perfil da região como pequenos e médios exportadores. 
Gráfico 9: Receita Anual com Exportação

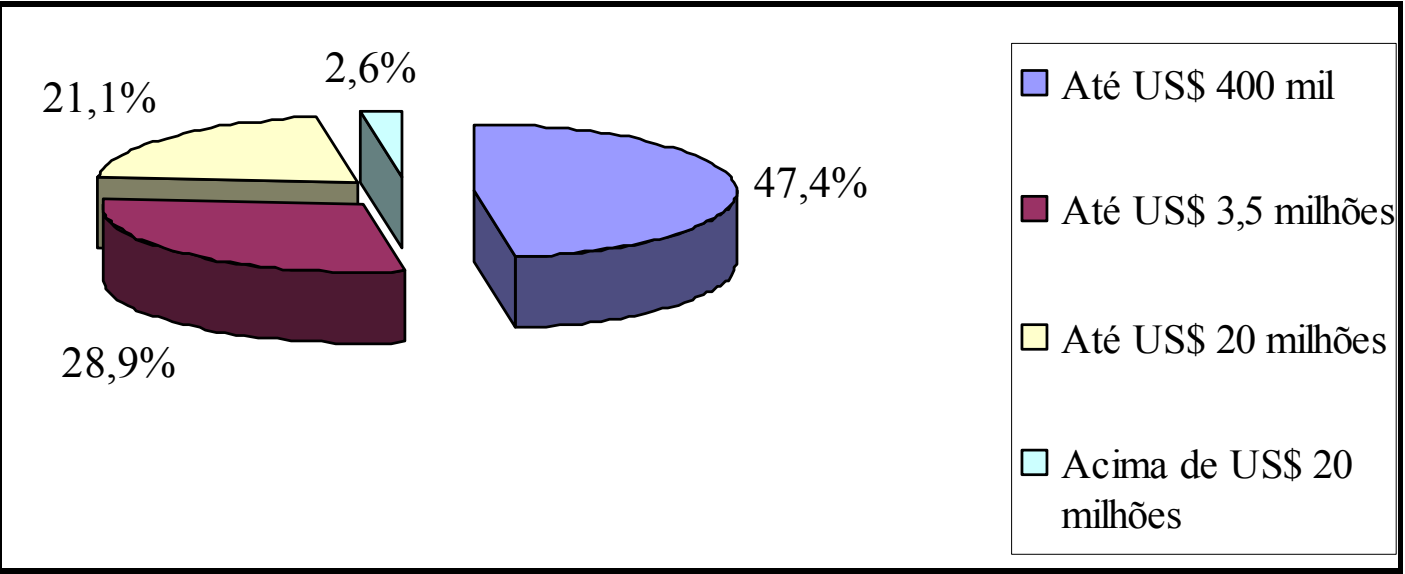

O Gráfico 10 mostra a participação das exportações no volume de vendas totais. Para este dado, foi solicitado ao respondente que apontasse em uma escala, evitando assim que considerasse exposição de informações confidenciais.

A maioria das empresas respondentes $(68,4 \%)$ informou que as exportações anuais representam até $25 \%$ do total das Vendas Totais (Gráfico 10) e apenas 7,9\% exporta acima de $75 \%$. Verificou-se também que nenhuma empresa exporta $100 \%$ da sua produção, o que representa que não há empresa exclusivamente exportadora.

Gráfico 10: Participação das Exportações no Volume de Vendas Totais Anuais

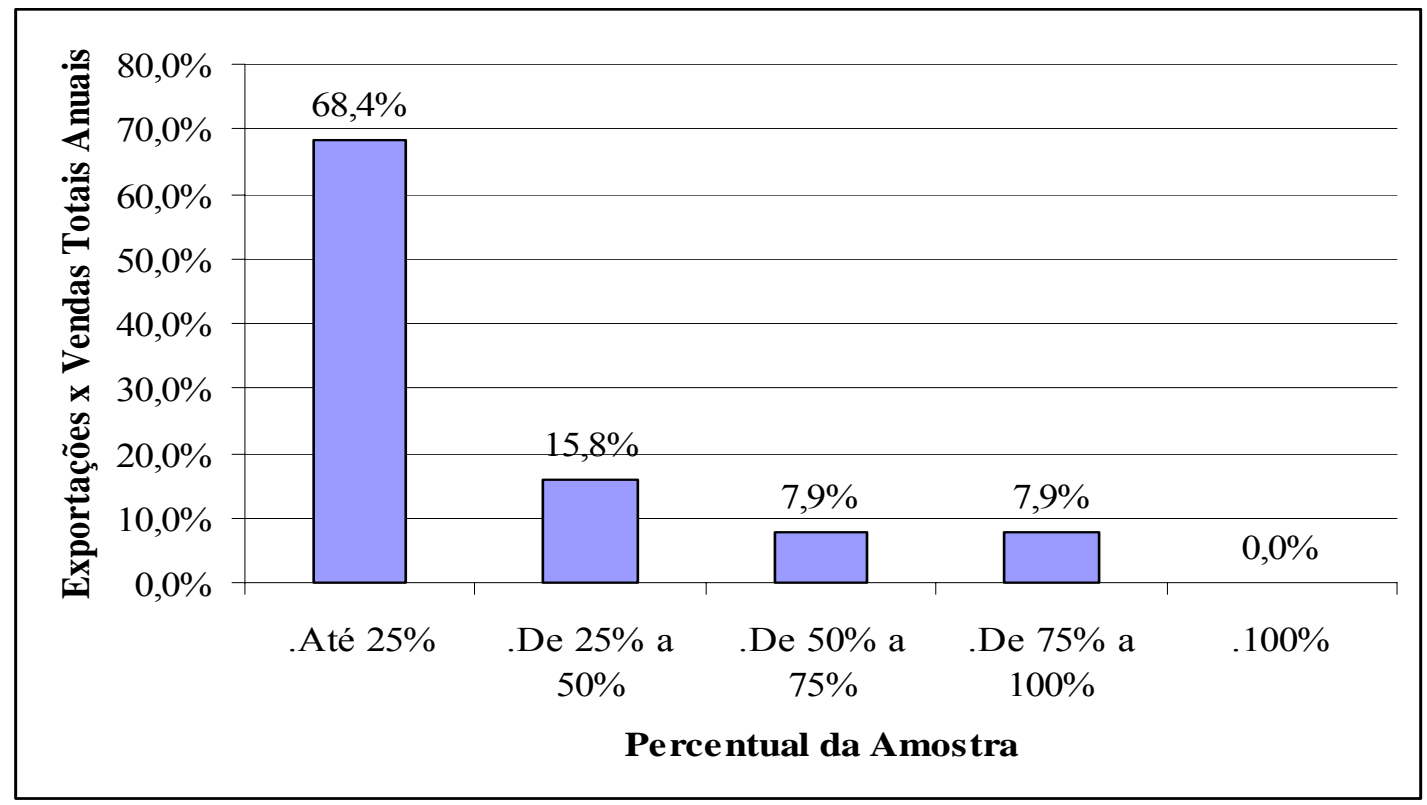


Para caracterizar o ramo de atividade das empresas respondentes, foi solicitada a informação do setor de atuação, cuja resposta foi livremente preenchida pelo respondente. Os setores foram agrupados para melhor visualização das respostas no Gráfico 11. O resultado mostra que $26 \%$ das empresas respondentes industrializam equipamentos, seguidas pela indústria sucroalcooleira (15\%), agropecuária (10\%) e equipamentos médicos $(10 \%)$. É possível observar também que alguns setores, diferentes dos tradicionalmente conhecidos na região, têm baixa participação na quantidade de empresas (3\%) que correspondem aos setores de Tecnologia e Sistemas, Química, Mineração e Equipamentos Agrícolas.

Gráfico 11: Setores de Atuação das Empresas Respondentes

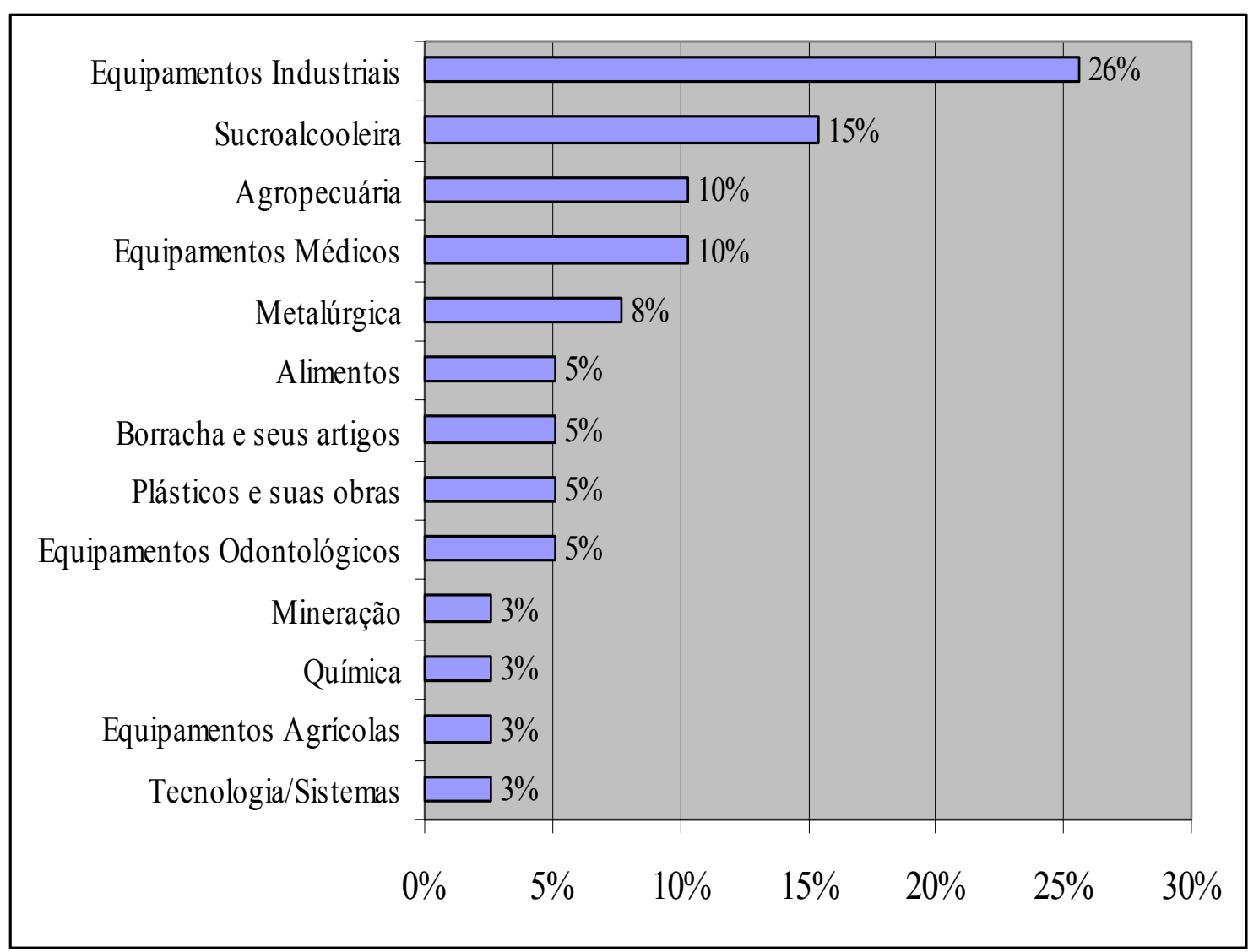

Com relação á experiência com exportação, observa-se no Gráfico 12 que 18,4\% das empresas exportam há menos de um ano e 31,6\% têm até 5 anos de atuação no mercado 
internacional. Estes totais perfazem $50 \%$, o que se observa que metade das empresas respondentes começou a atuar depois do ano 2002. Outro dado obtido na amostra é que $21,1 \%$ das empresas exportam há mais de 20 anos.

Gráfico 12: Experiência das Empresas com Exportação

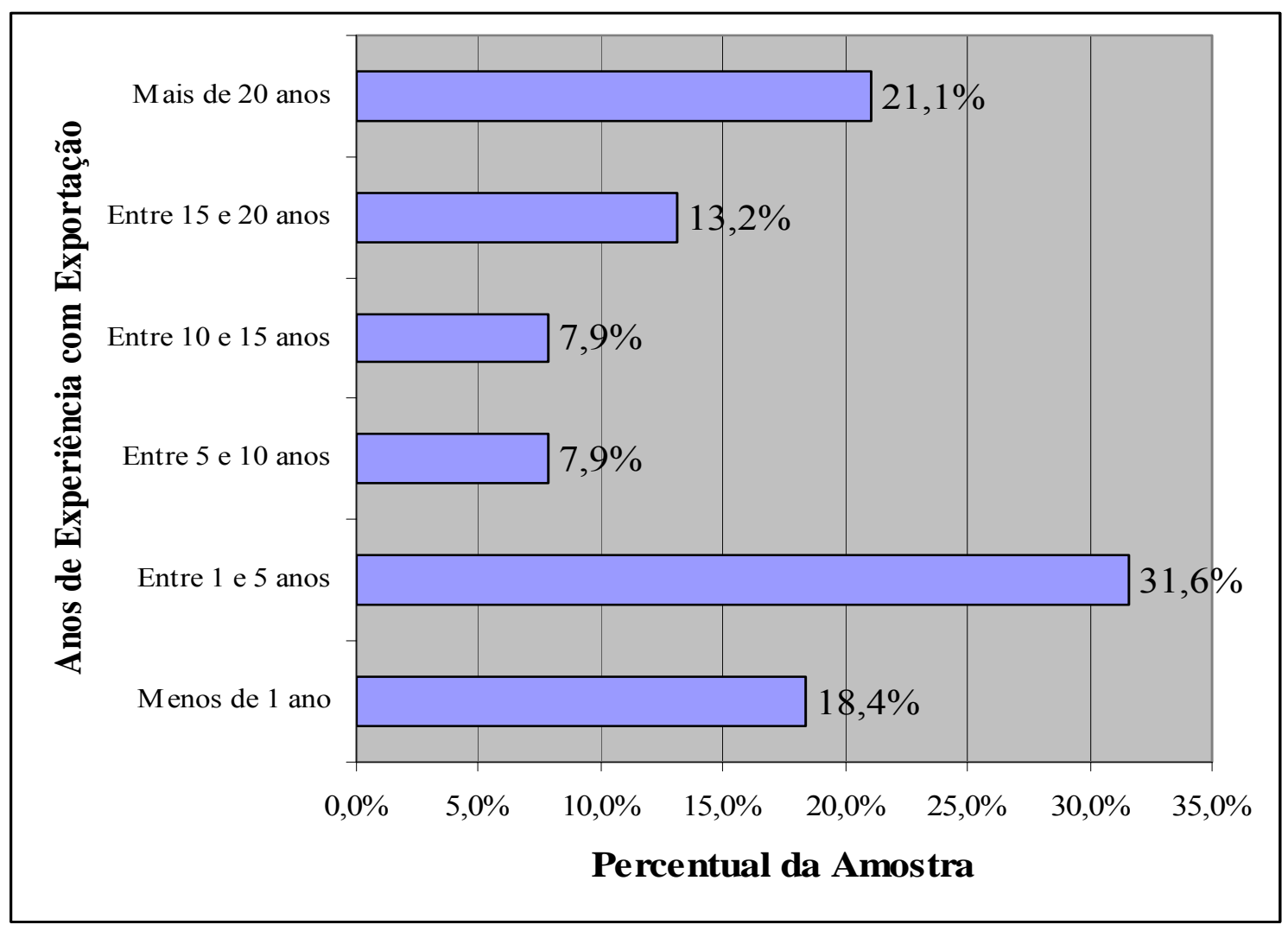

O Gráfico 13 descreve os dados obtidos com as respostas acerca do primeiro país que a empresa respondente exportou. Os resultados mostraram que a maior parte $(52,6 \%)$ começou com a Argentina (26,3\%), México (15,8\%) e Paraguai (10,5\%). Estes dados permitem concluir que as empresas exportadoras da região começaram por países vizinhos e com proximidade cultural com o Brasil, o que corrobora com a bibliografia revisada no Capítulo 2. 
Gráfico 13 - Primeira Exportação - PAÍS

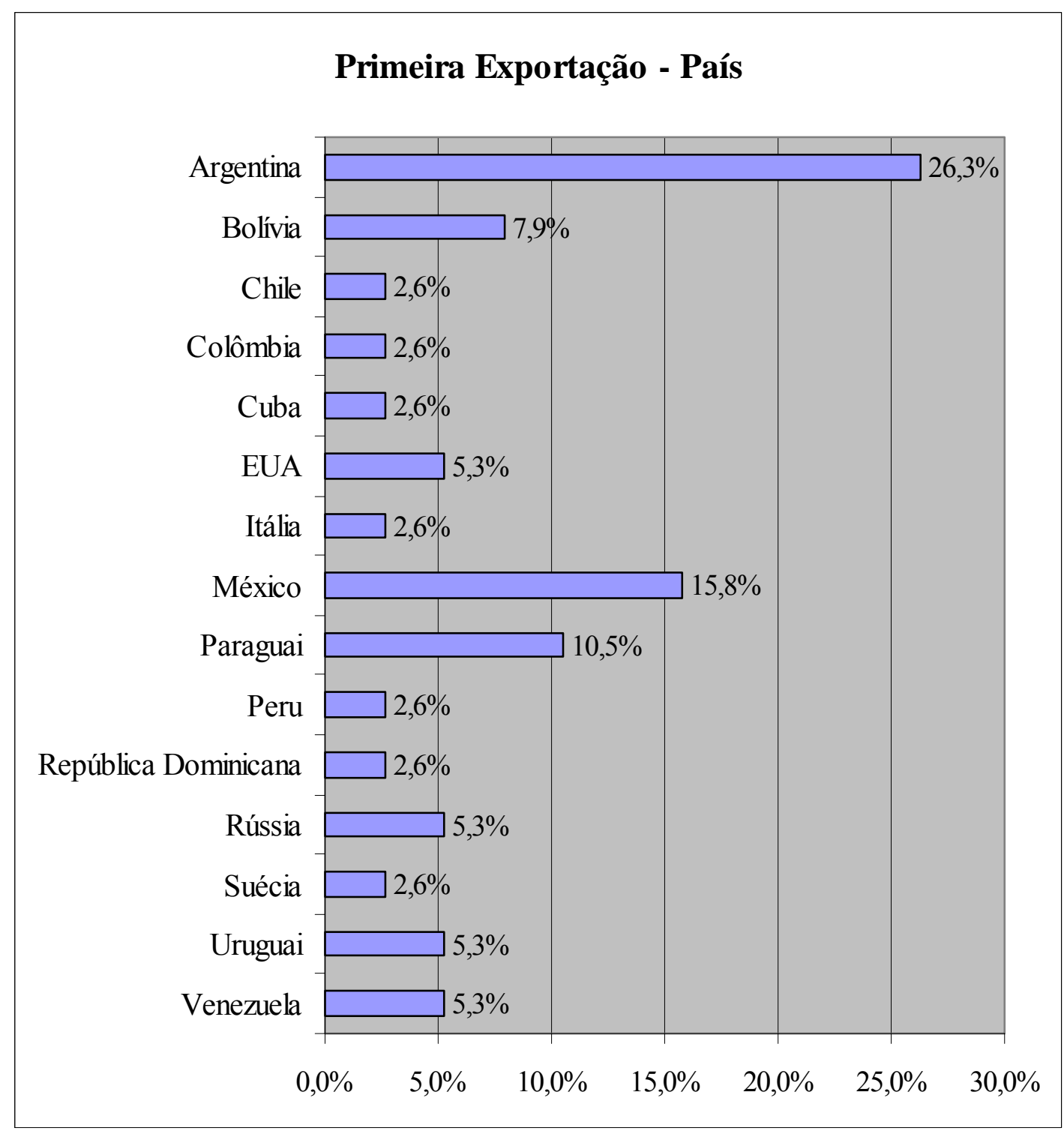

\subsubsection{Mercados de Atuação}

As empresas exportadoras da região de Ribeirão Preto exportam para vários mercados, onde muitas privilegiam a proximidade geográfica, regiões que apresentam maior mercado, barreiras menores, ou por outra razão específica. Buscou-se identificar quais os mercados que as empresas utilizam, sendo que a questão admitia mais de uma resposta. O resultado permitiu observar que a maioria (81,6\%) exporta para o Mercosul (Gráfico 14). 
Gráfico 14: Mercados de Atuação das empresas da região*

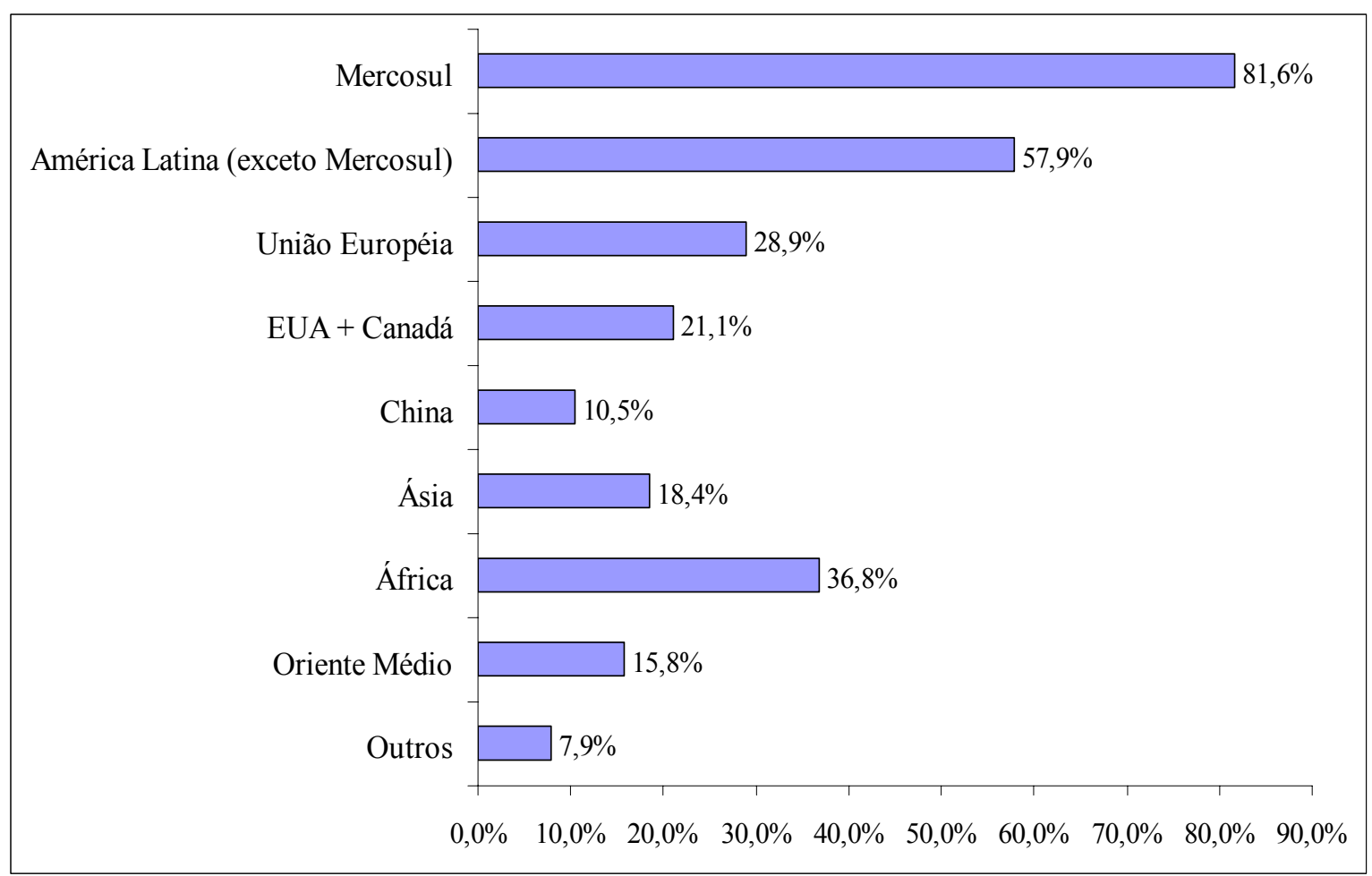

* A questão admitia mais de uma resposta

O Gráfico 14 mostra também que os respondentes atuam com grande representatividade na América Latina exceto os países do Mercosul (57,9\%). Em terceiro lugar está a África, com 36,8\%. A União Européia é um mercado no qual atuam $28,9 \%$ das empresas, seguida da participação dos EUA e Canadá com 21,1\%. Com relação à China, apesar da grande ênfase que a imprensa lhe tem dado nos últimos anos, foi citada por apenas 10,5\% das empresas da região como mercado de atuação.

\subsubsection{Perfil de Atuação}

Os respondentes apontaram também o perfil de atuação no mercado internacional. O resultado demonstra que $82 \%$ dos respondentes exportam diretamente, ou seja, sem a utilização de intermediários. 
Esta questão admitia mais de uma resposta, e mesmo assim, ficou claro o perfil de atuação das empresas pesquisadas, como exportadoras diretas. Outro fator importante é que $32 \%$ utilizam distribuidores próprios no exterior e 24\% exporta para distribuidores independentes. A utilização do "Exporta Fácil" obteve apenas 5\% das respostas (Gráfico $15)$.

Gráfico 15: Perfil de Atuação das Empresas Respondentes*

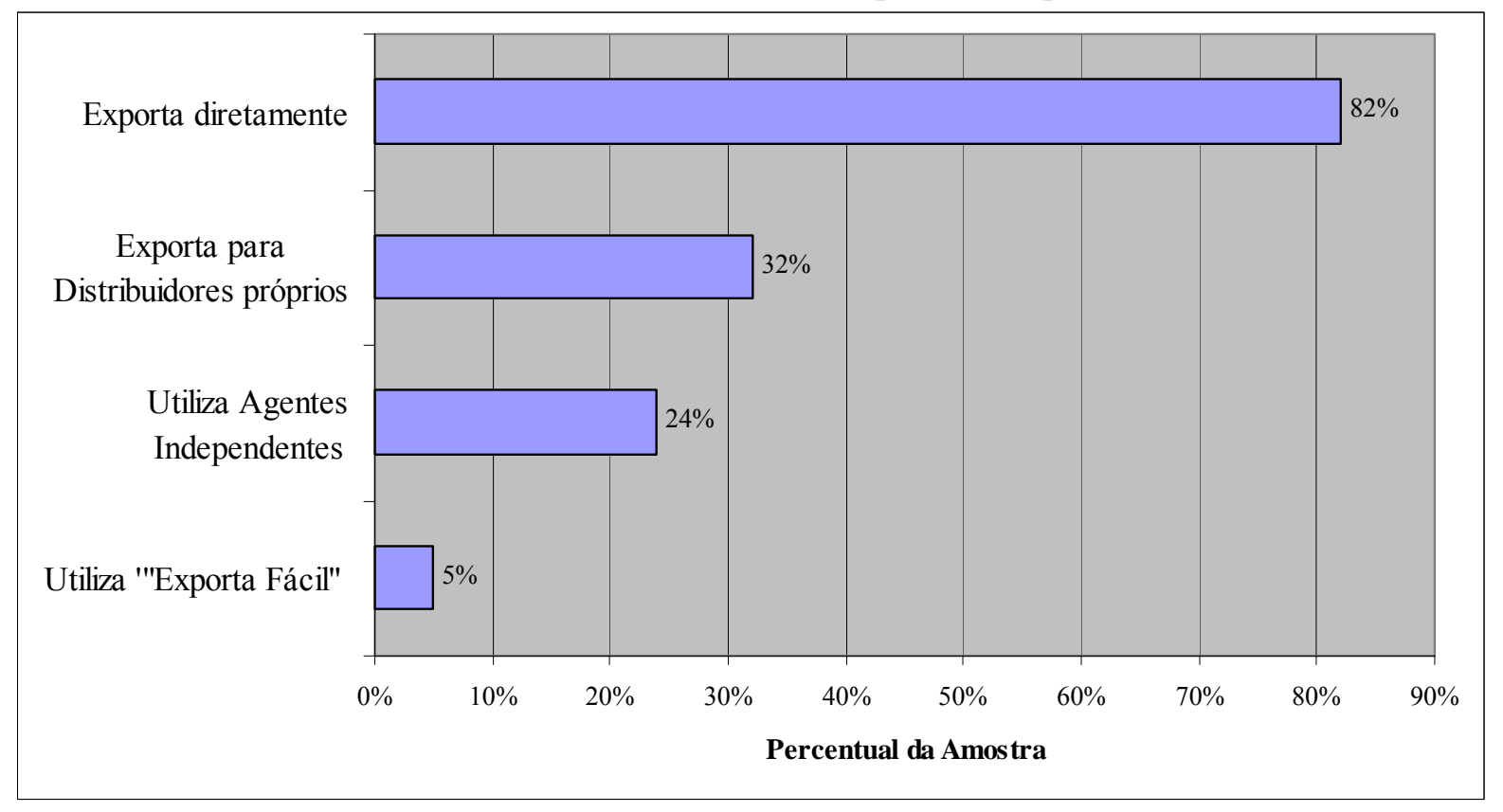

* A questão admitia mais de uma resposta

No bloco seguinte de perguntas, as empresas apontaram se buscavam constantemente novos mercados ou se os clientes é que as procuravam. Esta questão busca identificar se as empresas da região atuam ativa ou passivamente na atividade exportadora. O resultado está demonstrado no Gráfico 16, onde 55\% dos respondentes apontaram que a empresa busca constantemente novos mercados, enquanto que $45 \%$ apontaram que a empresa não busca novos mercados, pois são procuradas pelos clientes. 
Gráfico 16: Perfil de Atuação no Mercado Internacional

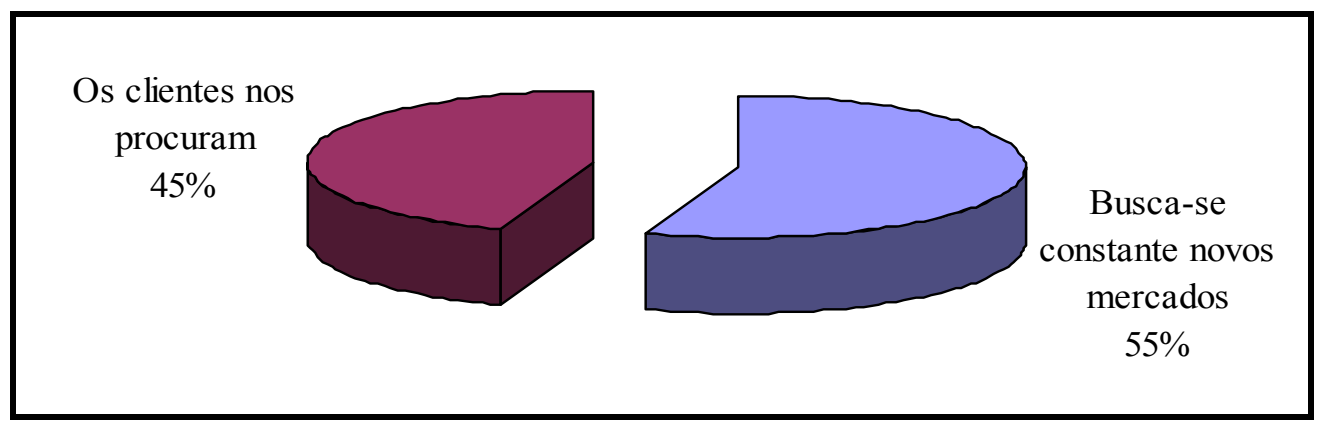

\subsection{Informações sobre os países alvo}

\subsubsection{Uso de Informações Gerais}

As questões sobre o uso de informações para atuação no mercado internacional, foco central desse trabalho, foram separadas em dois grandes grupos: Informações Gerais e Mercado Alvo. Primeiramente serão analisadas as informações do primeiro grupo: Uso de Informações Gerais sobre os países para os quais a empresa exporta (Tabela 15). Os resultados apresentados na Tabela 15 mostram os percentuais de cada resposta.

Tabela 15: Uso de Informações Gerais

\begin{tabular}{||l|c|c||c||c||}
\hline \multicolumn{1}{|c|}{ Informações gerais sobre o país alvo } & $\begin{array}{c}\text { Não } \\
\text { Usa }\end{array}$ & $\begin{array}{c}\text { Usa } \\
\text { pouco }\end{array}$ & $\begin{array}{c}\text { Usa } \\
\text { muito }\end{array}$ & $\begin{array}{c}\text { Usa } \\
\text { sempre }\end{array}$ \\
\hline \hline 1.Idioma utilizado nas transações internacionais & $15,8 \%$ & $5,3 \%$ & $28,9 \%$ & $\mathbf{5 0 , 0 \%}$ \\
\hline 2.Religião & $\mathbf{8 9 , 5 \%}$ & $7,9 \%$ & $0,0 \%$ & $2,6 \%$ \\
\hline 3.Inflação & $60,5 \%$ & $26,3 \%$ & $7,9 \%$ & $5,3 \%$ \\
\hline 4. Taxa de conversão da moeda do país alvo x Dólar dos EUA & $31,6 \%$ & $13,2 \%$ & $21,1 \%$ & $\mathbf{3 4 , 2 \%}$ \\
\hline 5. Renda per capita & $\mathbf{7 1 , 1 \%}$ & $13,2 \%$ & $10,5 \%$ & $5,3 \%$ \\
\hline 6. Volume de Reservas Internacionais & $\mathbf{8 1 , 6 \%}$ & $10,5 \%$ & $2,6 \%$ & $5,3 \%$ \\
\hline 7. PIB - Produto Interno Bruto & $68,4 \%$ & $23,7 \%$ & $2,6 \%$ & $5,3 \%$ \\
\hline 8. Taxa de desemprego & $\mathbf{7 6 , 3 \%}$ & $15,8 \%$ & $2,6 \%$ & $5,3 \%$ \\
\hline 9. Estabilidade Política & $36,8 \%$ & $28,9 \%$ & $18,4 \%$ & $15,8 \%$ \\
\hline 10. Relações diplomáticas com o Brasil & $44,7 \%$ & $21,1 \%$ & $15,8 \%$ & $18,4 \%$ \\
\hline 11. Existência de Acordos Comerciais com o Brasil & $36,8 \%$ & $7,9 \%$ & $28,9 \%$ & $\mathbf{2 6 , 3 \%}$ \\
\hline
\end{tabular}


Para visualização dos resultados mais representativos, as lacunas foram destacadas em negrito. No grupo de informações gerais (Tabela 15), as informações citadas como sempre utilizadas, estão o idioma que o país alvo usa nas transações internacionais (50\%), a taxa de conversão da moeda do país alvo com a moeda norte-americana $(34,2 \%)$ e a existência de acordos comerciais com o Brasil (26,3\%). No grupo de informações, citadas como não usadas, estão a religião $(89,5 \%)$, o volume de reservas internacionais $(81,6 \%)$, taxa de desemprego (76,3\%) e Renda Per Capita (71,1\%).

Estas informações (Tabela 15) compõem o ambiente de negócios internacionais citado pelos modelos apresentados no Capítulo 2, como importantes para uma empresa que atua no mercado internacional. O ambiente de negócios proporciona decisões criteriosas, levando-se em consideração proximidade geográfica, cultural e política que podem representar facilitadores na inserção internacional (LEONIDOU \& KATSIKEAS, 1996 e KEEGAN, 2005). Minervini (2005) destaca que conhecer o quadro macroeconômico do país possibilita avaliar a conveniência de fazer ou não negócios com este país. No entanto, os resultados obtidos revelam que as empresas não usam estas informações para atuar no mercado internacional, com tendência a ignorar estas informações como estratégia para tomada de decisão.

\subsubsection{Análise Fatorial do Uso das Informações Gerais}

Para analisar os dados da Tabela 15, de forma a comparar com a teoria, as respostas foram tabuladas utilizando o pacote SPSS (Statitical Package for the Social Sciences), para buscar entendimento das respostas e adequação dos resultados aos modelos apresentados na revisão bibliográfica. 
Para avaliar a adequação da Análise Fatorial, foi realizado o teste KMO (Kaiser Meyer Olkin) e Bartlett para medir a significância geral de todas as correlações em uma matriz de correlação. De acordo com Hair et. al. (2005), a significância neste teste deve ser $K M O \geq 0,5$, para que a ferramenta seja considerada adequada ao problema.

Figura 9: Teste $K M O$ - Uso de Informações Gerais

KMO and Bartlett's Test

\begin{tabular}{|c|c|c|}
\hline \multicolumn{2}{|c|}{$\begin{array}{l}\text { Kaiser-Meyer-Olkin Measure of Sampling } \\
\text { Adequacy. }\end{array}$} & 772, \\
\hline \multirow{3}{*}{$\begin{array}{l}\text { Bartlett's Test of } \\
\text { Sphericity }\end{array}$} & Approx. Chi-Square & 214,756 \\
\hline & $d f$ & 55 \\
\hline & Sig. &, 000 \\
\hline
\end{tabular}

O resultado obtido (Figura 9) mostra que a análise é consistente, pois apresenta $K M O$ igual a 0,772. Com este resultado, foi elaborada a Matriz de Variância Explicada, apresentada na Figura 10. O resultado mostrou que foram extraídos três fatores e a variância acumulada é de $68,023 \%$.

Figura 10: Matriz de Variância Total explicada - Uso de Informações Gerais

Total Variance Explained

\begin{tabular}{|l|r|r|r|}
\hline \multirow{2}{*}{ Component } & \multicolumn{3}{|c|}{ Rotation Sums of Squared Loadings } \\
\cline { 2 - 4 } & Total & $\begin{array}{c}\text { \% of } \\
\text { Variance }\end{array}$ & $\begin{array}{c}\text { Cumulativ } \\
\text { e \% }\end{array}$ \\
\hline 1 & 3,867 & 35,155 & 35,155 \\
2 & 2,270 & 20,639 & 55,794 \\
3 & 1,345 & 12,229 & 68,023 \\
\hline
\end{tabular}

Extraction Method: Principal Component Analysis.

Foi realizada a análise fatorial, técnica exploratória para verificar correlações entre variáveis e agrupa-las em fatores (dimensões) independentes. Utilizando-se o método de 
componentes principais e a rotação VARIMAX obteve-se o resultado mostrado na Figura 11. Os valores dispostos nas colunas dos componentes indicam os fatores agrupados, com as respectivas cargas fatoriais, ou seja, a correlação de cada variável com cada fator.

Figura 11: Matriz de Componentes Principais: Uso de Informações Gerais

Rotated Component Matrix a

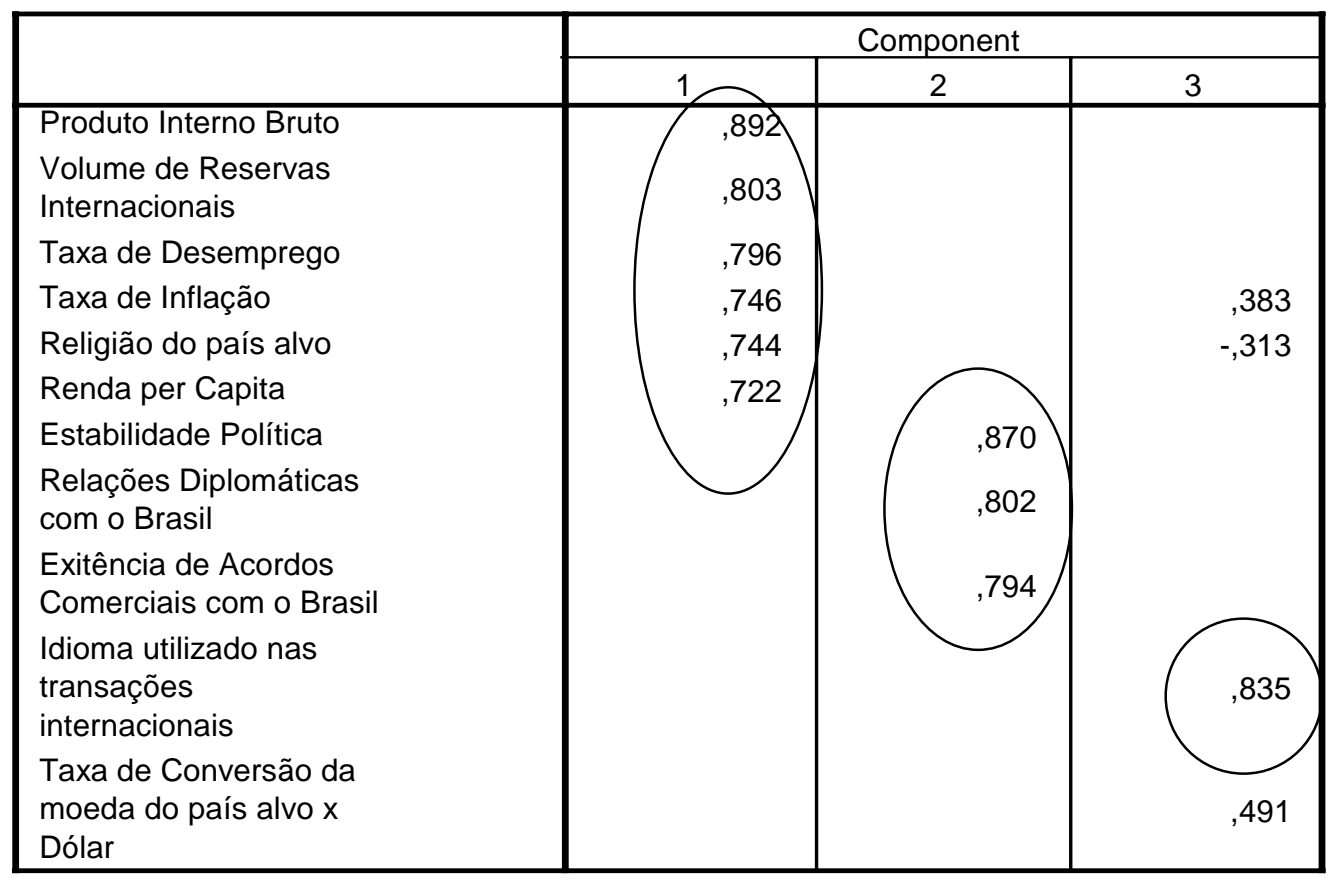

Extraction Method: Principal Component Analysis.

Rotation Method: Varimax with Kaiser Normalization.

a. Rotation converged in 5 iterations.

A Matriz dos Componentes Principais (Figura 11) permitiu a identificação de três fatores:

Fator 1: Produto Interno Bruto, Volume de Reservas Internacionais, Taxa de Desemprego, Taxa de Inflação, Religião do País Alvo e Renda Per Capita.

Fator 2: Estabilidade Política, Relações Diplomáticas com o Brasil e Existência de Acordos Comerciais com o Brasil.

Fator 3: Idioma Utilizado no País Alvo. 
Os modelos discutidos no Capítulo 2, que trata do ambiente de negócios internacionais, dimensionam as informações do macroambiente que influenciam as decisões das empresas como aspectos sócio-culturais, legais, políticos, econômicos e regulatórios (KEEGAN, 2005; HILL, 2005, DOWLE \& LOWE, 2004). Os dados obtidos permitem nomear os fatores, considerando as variáveis que autores definem como pertencente a cada ambiente:

Fator 1: Ambiente Econômico

Fator 2: Ambiente Político/Regulatório

Fator 3: Ambiente Sócio-Cultural

\subsubsection{Uso de Informações de Mercado}

Com relação às Informações de Mercado, as empresas exportadoras da região de Ribeirão Preto revelaram que as informações sobre o mercado são mais utilizadas do que as informações gerais. O resultado pode ser visualizado na Tabela 16, a seguir.

Tabela 16: Uso de Informações de Mercado

\begin{tabular}{||l|c||c||c||c||}
\hline \multicolumn{1}{|c|}{ Informações sobre o Mercado alvo } & $\begin{array}{c}\text { Não } \\
\text { usa }\end{array}$ & $\begin{array}{c}\text { Usa } \\
\text { pouco }\end{array}$ & $\begin{array}{c}\text { Usa } \\
\text { muito }\end{array}$ & $\begin{array}{c}\text { Usa } \\
\text { sempre }\end{array}$ \\
\hline \hline Concorrentes internacionais que atuam no mercado & $23,7 \%$ & $10,5 \%$ & $28,9 \%$ & $36,8 \%$ \\
\hline Existência de fabricantes & $\mathbf{3 4 , 2 \%}$ & $10,5 \%$ & $26,3 \%$ & $28,9 \%$ \\
\hline Estimativa de demanda do produto & $21,1 \%$ & $10,5 \%$ & $26,3 \%$ & $42,1 \%$ \\
\hline Capacidade de pagamento dos compradores & $7,9 \%$ & $0,0 \%$ & $26,3 \%$ & $\mathbf{6 5 , 8 \%}$ \\
\hline Preço praticado pelos concorrentes & $10,5 \%$ & $13,2 \%$ & $34,2 \%$ & $42,1 \%$ \\
\hline Impostos incidentes sobre o seu produto & $26,3 \%$ & $7,9 \%$ & $28,9 \%$ & $36,8 \%$ \\
\hline Benefícios fiscais para o seu produto & $23,7 \%$ & $7,9 \%$ & $23,7 \%$ & $\mathbf{4 4 , 7 \%}$ \\
\hline Exigências e normas para o seu produto & $13,2 \%$ & $2,6 \%$ & $26,3 \%$ & $\mathbf{5 7 , 9 \%}$ \\
\hline Custos logísticos no país alvo & $\mathbf{3 6 , 8 \%}$ & $5,3 \%$ & $26,3 \%$ & $31,6 \%$ \\
\hline Disponibilidade de transporte para o país alvo & $13,2 \%$ & $10,5 \%$ & $34,2 \%$ & $42,1 \%$ \\
\hline Procedimentos burocráticos para importação & $26,3 \%$ & $5,3 \%$ & $34,2 \%$ & $34,2 \%$ \\
\hline
\end{tabular}


$\mathrm{Na}$ Tabela 16, os resultados mais representativos foram destacadas em negrito nas respectivas colunas. As Informações de Mercado (Tabela 16), sempre utilizadas pelos exportadores estão a Capacidade de Pagamento dos Compradores (65,8\%), Exigência e Normas para o produto exportado $(57,9 \%)$ e Benefícios Fiscais $(44,7 \%)$. Com relação às informações de mercado citadas pelos respondentes como não usadas, estão principalmente a Existência de Fabricantes no país alvo (34,2\%) e Custos Logísticos $(36,8 \%)$.

As informações da Tabela 16 compõem as informações de mercado citadas pelos pesquisadores, e apresentados no Capítulo 2, como importantes para uma empresa que atua no mercado internacional, quando se avalia as condições de negócio para o produto exportado. Com esta relevância, decidiu-se explorar mais as respostas dos questionários, agrupando-as em “ Não Usa" e "Usa”, em ordem de maior citação (Tabela17).

Tabela 17: Informações sobre o Mercado Alvo por ordem de citação

\begin{tabular}{|l|l|l||}
\hline Informações sobre o Mercado alvo & Não usa & Usa \\
\hline \hline Capacidade de pagamento dos compradores & $7,9 \%$ & $92,1 \%$ \\
\hline Preço praticado pelos concorrentes & $10,5 \%$ & $89,5 \%$ \\
\hline Exigências e normas para o seu produto & $13,2 \%$ & $86,8 \%$ \\
\hline Disponibilidade de transporte para o país alvo & $13,2 \%$ & $86,8 \%$ \\
\hline Estimativa de demanda do produto & $21,1 \%$ & $78,9 \%$ \\
\hline Concorrentes internacionais que atuam no mercado & $23,7 \%$ & $76,3 \%$ \\
\hline Benefícios fiscais para o seu produto & $23,7 \%$ & $76,3 \%$ \\
\hline Impostos incidentes sobre o seu produto & $26,3 \%$ & $73,7 \%$ \\
\hline Procedimentos burocráticos para importação & $26,3 \%$ & $73,7 \%$ \\
\hline Existência de fabricantes & $34,2 \%$ & $65,8 \%$ \\
\hline Custos logísticos no país alvo & $36,8 \%$ & $63,2 \%$ \\
\hline
\end{tabular}

Observa-se na Tabela 17 que a informação mais utilizada pelas empresas exportadoras da região é a capacidade de pagamento dos compradores $(92,1 \%)$. Em seguida, o preço 
praticado pelos concorrentes $(89,5 \%)$, exigências e normas para os produtos $(86,8 \%)$ e disponibilidade de transporte para o país alvo $(86,8 \%)$, foram as informações mais citadas.

Em outro extremo, estão as informações com baixa representatividade na resposta que são os custos logísticos no país alvo $(63,2 \%)$ e a existência de fabricantes no mercado alvo $(65,8 \%)$

\subsubsection{Análise Fatorial do Uso das Informações de Mercado}

Para avaliar a adequação da Análise Fatorial, foi realizado o teste KMO (Kaiser Meyer Olkin) e Bartlett para medir a significância geral de todas as correlações em uma matriz de correlação, com os dados apurados na Tabela 16 e a adequação da técnica. O resultado pode ser visualizado na Figura 12.

Figura 12: Teste $K M O$ - Uso de Informações de Mercado

KMO and Bartlett's Test

\begin{tabular}{|c|c|c|}
\hline \multicolumn{2}{|c|}{$\begin{array}{l}\text { Kaiser-Meyer-Olkin Measure of Sampling } \\
\text { Adequacy. }\end{array}$} & 821, \\
\hline $\begin{array}{l}\text { Bartlett's Test of } \\
\text { Sphericity }\end{array}$ & $\begin{array}{l}\text { Approx. Chi-Square } \\
\text { df } \\
\text { Sig. }\end{array}$ & $\begin{array}{r}264,537 \\
55 \\
, 000\end{array}$ \\
\hline
\end{tabular}

O resultado obtido no Teste $K M O$ mostra que a análise é consistente, pois apresenta $K M O$ igual a 0,821. Foi elaborada a Matriz de Variância Explicada, apresentada na Figura 13, apresentando dois fatores e a variância acumulada é de 66,584\%. 
Figura 13: Matriz de Variância Total Explicada - Uso de Informações de Mercado

Total Variance Explained

\begin{tabular}{|l|c|c|c|}
\hline \multirow{2}{*}{ Component } & \multicolumn{3}{|c|}{ Rotation Sums of Squared Loadings } \\
\cline { 2 - 4 } & Total & $\begin{array}{c}\text { \% of } \\
\text { Variance }\end{array}$ & $\begin{array}{c}\text { Cumulativ } \\
\text { e } \%\end{array}$ \\
\hline 1 & 4,366 & 39,694 & 39,694 \\
2 & 2,958 & 26,890 & 66,584 \\
\hline
\end{tabular}

Extraction Method: Principal Component Analysis.

Foi realizada a análise fatorial, técnica exploratória para verificar correlações entre variáveis e agrupa-las em fatores (dimensões) independentes. Utilizando-se o método de componentes principais e a rotação VARIMAX obteve-se o resultado mostrado na Figura 14. Os valores dispostos nas colunas dos componentes indicam os fatores agrupados, com as respectivas cargas fatoriais, ou seja, a correlação de cada variável com cada fator.

A Matriz dos Componentes Principais (Figura 14) permitiu a identificação de dois grupos de fatores. Para melhor observação, foram retiradas as variáveis: "Existência de Fabricantes Nacionais" e "Impostos Incidentes sobre seu produto" que apresentaram componentes nos dois fatores e que poderiam resultar em análise equivocada. 
Figura 14: Matriz de Componentes Principais: Uso de Informações de Mercado

Rotated Component Matriæ

\begin{tabular}{|c|c|c|}
\hline & \multicolumn{2}{|c|}{ Component } \\
\hline & 1 & 2 \\
\hline $\begin{array}{l}\text { Preço praticado pelos } \\
\text { concorrentes }\end{array}$ & 835, & 325 \\
\hline $\begin{array}{l}\text { Estimativa de demanda } \\
\text { do produto no mercado } \\
\text { alvo }\end{array}$ & ,823 & \\
\hline $\begin{array}{l}\text { Exigências e Normas } \\
\text { para o seu produto }\end{array}$ & ,798 & \\
\hline $\begin{array}{l}\text { Benefícios Fiscais para } \\
\text { o seu produto }\end{array}$ & ,770 & \\
\hline $\begin{array}{l}\text { Concorrentes } \\
\text { Internacionais que } \\
\text { atuam no mercado alvo }\end{array}$ & ,731 & ,344 \\
\hline $\begin{array}{l}\text { Capacidade de } \\
\text { Pagamento dos } \\
\text { compradores }\end{array}$ & 697 & ,371 \\
\hline $\begin{array}{l}\text { Existência de } \\
\text { fabricantes nacionais } \\
\text { ne mercado alvo }\end{array}$ & ,515 &, 510 \\
\hline $\begin{array}{l}\text { Custos Logisticos para } \\
\text { seu produto }\end{array}$ & & ,853 \\
\hline $\begin{array}{l}\text { Procedimentos } \\
\text { Burocrráticos para } \\
\text { importação }\end{array}$ & & ,822 \\
\hline $\begin{array}{l}\text { Disponibilidade de } \\
\text { Transporte para o país } \\
\text { alvo }\end{array}$ & ,432 & 670 \\
\hline $\begin{array}{l}\text { Hmpostos incidentes } \\
\text { sobre o seu produto }\end{array}$ &, 511 & ,618 \\
\hline
\end{tabular}

Extraction Method: Principal Component Analysis.

Rotation Method: Varimax with Kaiser Normalization.

a. Rotation converged in 3 iterations.

A retiradas das duas variáveis (Existência de Fabricantes Nacionais e Impostos Incidentes sobre seu produto) resultou nos resultados: Teste KMO 0,798 (Figura 15) e Variância Total Explicada de 69,944\% (Figura 16), melhorando o resultado apresentado na Figura 13, cujo resultado foi de $66,584 \%$. 
Figura 15: Resultado do Teste $K M O$ - Uso de Informações de Mercado

KMO and Bartlett's Test

\begin{tabular}{|c|c|c|}
\hline \multicolumn{2}{|c|}{$\begin{array}{l}\text { Kaiser-Meyer-Olkin Measure of Sampling } \\
\text { Adequacy. }\end{array}$} & 798, \\
\hline $\begin{array}{l}\text { Bartlett's Test of } \\
\text { Sphericity }\end{array}$ & $\begin{array}{l}\text { Approx. Chi-Square } \\
\text { df } \\
\text { Sig. }\end{array}$ & $\begin{array}{r}208,992 \\
36 \\
000\end{array}$ \\
\hline
\end{tabular}

Figura 16: Resultado da Variância Total Explicada - Uso de Informações de Mercado

Total Variance Explained

\begin{tabular}{|l|c|c|c|}
\hline \multirow{2}{*}{ Component } & \multicolumn{3}{|c|}{ Rotation Sums of Squared Loadings } \\
\cline { 2 - 4 } & Total & $\begin{array}{c}\% \text { of } \\
\text { Variance }\end{array}$ & $\begin{array}{c}\text { Cumulativ } \\
\text { e } \%\end{array}$ \\
\hline 1 & 3,966 & 44,070 & 44,070 \\
2 & 2,329 & 25,874 & 69,944 \\
\hline
\end{tabular}

Extraction Method: Principal Component Analysis.

Com este resultado, foi realizada a rotação dos fatores (Figura 17) para verificar quais variáveis pertencem a cada fator. Os valores dispostos nas colunas dos Componentes indicam o agrupamento dos fatores agrupados, com as respectivas cargas fatoriais.

O resultado da Matriz de Componentes Principais Rotacionada permitiu a identificação de dois fatores.

Fator 1: Preço Praticado pelos Concorrentes, Estimativa de Demanda para Seu Produto, Benefícios Fiscais para Seu Produto, Concorrentes Internacionais que atuam no Mercado Alvo e Capacidade de Pagamento dos Compradores.

Fator 2: Custos Logísticos para seu produto, Procedimentos Burocráticos para Importação e Disponibilidade de Transporte para o país alvo. 
Figura 17: Matriz de Componentes Rotacionada: Uso de Informações de Mercado

Rotated Component Matrix ${ }^{\mathrm{a}}$

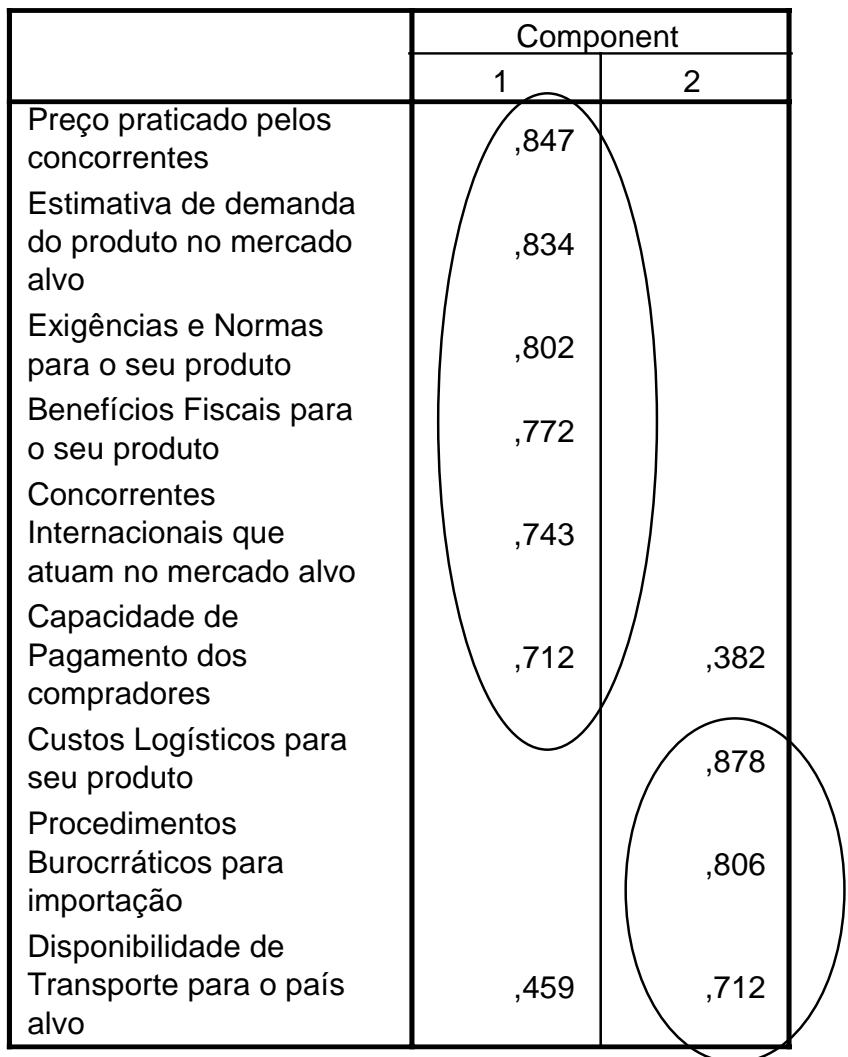

Extraction Method: Principal Component Analysis. Rotation Method: Varimax with Kaiser Normalization.

a. Rotation converged in 3 iterations.

A base teórica deste trabalho, apresentada no Capítulo 2, aborda os temas que focam o ambiente de negócios e que foram delimitadas pelos autores. Minervini (2005) sumariza as informações em quatro grupos:

1- Informações em nível interno do país exportador;

2- Informações sobre o mercado internacional;

3- Informações específicas sobre o produto; e

4- Informações referentes ao mercado selecionado.

O resultado deste grupo de informações evidencia que as empresas exportadoras da região, separam as informações em dois grandes blocos: Oferta/Demanda do Produto (Fator 
1) e Logística Internacional (Fator 2), não se levando em conta, a divisão proposta pelos autores e que foram discutidas no Capítulo 2 (KEEGAN, 2005; DOWLE \& LOWE, 2004; HILL, 2005)

A seguir serão analisadas as fontes de informação citadas pelos respondentes da pesquisa.

\subsection{Fontes de Informações sobre os países alvo}

O terceiro grupo de questões relacionadas à informação sobre os países que a empresa exporta trata da fonte das informações. Os dados obtidos podem ser visualizados no Gráfico 17 a seguir.

Gráfico 17: Fontes de Informação Utilizadas pelas empresas respondentes*

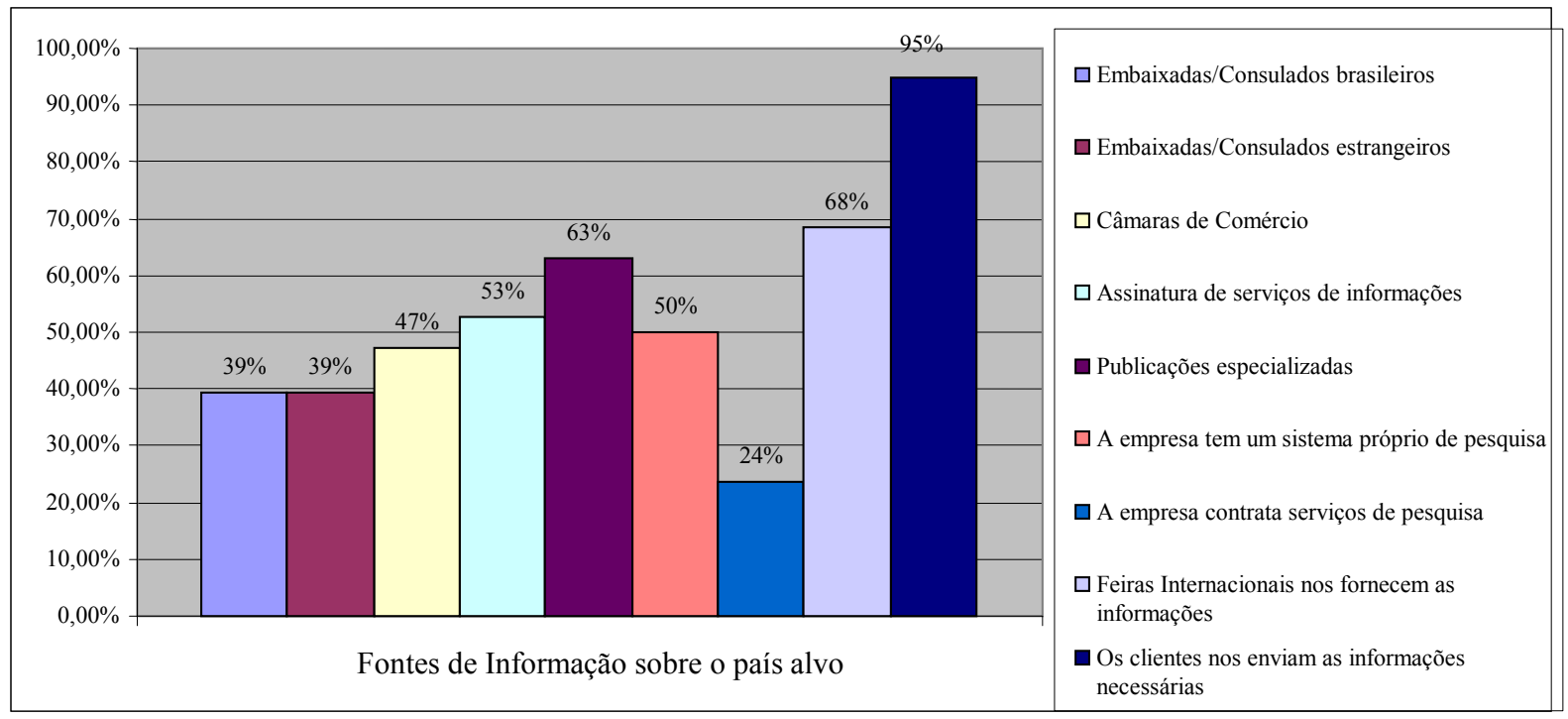

* A questão admitia mais de uma resposta 
O resultado obtido (Gráfico 17) mostra que 95\% das empresas recebem as informações necessárias do próprio cliente. Em seguida, os respondentes apontaram as Feiras Internacionais (68\%) e as Publicações Especializadas (63\%) como fontes de informação sobre o mercado alvo. As fontes menos citadas (24\%) foram a contratação de serviços de pesquisa e as representações diplomáticas, tanto do Brasil (39\%) quanto do país alvo (39\%).

\subsubsection{Análise Fatorial do Uso das Fontes de Informações}

As Fontes de Informação citadas pelos respondentes foram submetidas ao teste KMO (Kaiser Meyer Olkin) e Bartlett (Figura 18) para medir a significância geral de todas as correlações em uma matriz de correlação.

Figura 18: Teste $K M O$ - Fontes de Informações sobre o País Alvo

KMO and Bartlett's Test

\begin{tabular}{|c|c|c|}
\hline \multicolumn{2}{|c|}{$\begin{array}{l}\text { Kaiser-Meyer-Olkin Measure of Sampling } \\
\text { Adequacy. }\end{array}$} & 640, \\
\hline $\begin{array}{l}\text { Bartlett's Test of } \\
\text { Sphericity }\end{array}$ & $\begin{array}{l}\text { Approx. Chi-Square } \\
\text { df } \\
\text { Sig. }\end{array}$ & $\begin{array}{r}149,100 \\
36 \\
, 000\end{array}$ \\
\hline
\end{tabular}

O resultado obtido no Teste $K M O$ mostra que a análise é consistente, pois apresenta $K M O$ igual a 0,640. Foi elaborada a Matriz de Variância Explicada, apresentada na Figura 19, apresentando dois fatores e a variância acumulada é de 63,860\%. 
Figura 19: Variância Total Explicada - Fontes de Informações sobre o País Alvo

Total Variance Explained

\begin{tabular}{|l|r|r|r|}
\hline \multirow{2}{*}{ Component } & \multicolumn{3}{|c|}{ Rotation Sums of Squared Loadings } \\
\cline { 2 - 4 } & Total & $\begin{array}{c}\text { \% of } \\
\text { Variance }\end{array}$ & $\begin{array}{c}\text { Cumulativ } \\
\text { e \% }\end{array}$ \\
\hline 1 & 2,485 & 27,609 & 27,609 \\
2 & 2,061 & 22,903 & 50,512 \\
3 & 1,201 & 13,348 & 63,860 \\
\hline
\end{tabular}

Extraction Method: Principal Component Analysis.

A seguir, apresenta-se o resultado da análise fatorial para verificar correlações entre variáveis e agrupa-las em fatores (dimensões) independentes. Utilizando-se o método de componentes principais e a rotação VARIMAX obteve-se o resultado mostrado na Figura 20.

Figura 20: Matriz dos Componentes Principais: Fontes de Informação sobre o País Alvo 
Rotated Component Matrik

\begin{tabular}{|c|c|c|c|}
\hline & \multicolumn{3}{|c|}{ Component } \\
\hline & 1 & 2 & 3 \\
\hline $\begin{array}{l}\text { Embaixadas/Consulados } \\
\text { Estrangeiros }\end{array}$ & 921 & & \\
\hline $\begin{array}{l}\text { Embaixadas/Consulados } \\
\text { Brasileiros }\end{array}$ & 905, & & \\
\hline $\begin{array}{l}\text { Assinatura de Serviços de } \\
\text { Informação }\end{array}$ & 45 & ,393 & \\
\hline $\begin{array}{l}\text { A empresa contrata } \\
\text { serviços de informação }\end{array}$ & ,457 & 340, & \\
\hline $\begin{array}{l}\text { Feiras Internacionais nos } \\
\text { fornecem informações } \\
\text { necessárias }\end{array}$ & & ,844 & \\
\hline Câmaras de Comércio & & ,762 & \\
\hline $\begin{array}{l}\text { Publicações } \\
\text { Especializadas }\end{array}$ & ,455 & ,637 & \\
\hline $\begin{array}{l}\text { Os clientes nos enviam } \\
\text { as informações } \\
\text { necessárias }\end{array}$ & & & ,774 \\
\hline $\begin{array}{l}\text { A empresa tem um } \\
\text { sistema próprio de } \\
\text { pesquisa }\end{array}$ & & & 611 \\
\hline
\end{tabular}

Extraction Method: Principal Component Analysis.

Rotation Method: Varimax with Kaiser Normalization.

a. Rotation converged in 7 iterations.

A Matriz dos Componentes Principais (Figura 20) permitiu a identificação de três fatores:

Fator 1: Embaixadas/Consulados Brasileiros e Estrangeiros

Fator 2: Feiras Internacionais e Câmaras de Comércio

Fator 3: Informações obtidas nas relações com os Clientes

Minervini (2005) aponta diversas fontes de informação e relaciona estas fontes de acordo com o tipo de informação. As principais fontes citadas pelo autor são os organismos oficiais (Embaixadas e Consulados), as instituições de comércio bilateral (Câmaras de comércio e as agências promotoras de feiras internacionais e rodadas de negócio) e empresas especializadas, que geralmente são responsáveis pela edição de periódicos que contêm informações setoriais sobre o mercado internacional. 
Wood e Robertson (2000) apontaram as agências governamentais, os bancos e as instituições de apoio à exportação, enquanto que Keegan (2005) e Hill (2005) citam que as principais fontes de informação são os órgãos oficiais, ligados ao intercâmbio comercial dos países.

O resultado pode, então, ser assim identificado, de acordo com a base teórica:

Fator 1: Informações Oficiais

Fator 2: Informações Especializadas

Fator 3: Informações fornecidas pelo cliente

A seguir serão apresentadas análises de correlação entre as variáveis da pesquisa para aprofundamento do tema.

\subsection{Análise dos Dados}

Do referencial bibliográfico, pode-se verificar que a medida que a empresa adquire experiência no mercado internacional, maior será a necessidade de informações. Com base neste referencial foram feitas preliminarmente duas análises:

1. Tempo de experiência x Volume de Exportações

2. Tempo de experiência x Quantidade de Mercados

\subsection{1 - Análise do Tempo de Experiência x Volume de Exportações}

Esta análise considerou a experiência com exportação, o tempo de decorrido entre a primeira exportação e o ano 2007. Com relação ao volume de exportação, considerou-se a representatividade da exportação em relação ao volume total anual de vendas da empresa 
respondente. $\mathrm{O}$ questionário utilizou uma escala para que o respondente apontasse em termos percentuais a participação das exportações no volume de vendas totais anuais. Estes percentuais foram considerados em uma escala de 1 a 4 (Tabela 18) para construir a matriz de correlação (Figura 21).

Tabela 18: Escala do Volume de Exportações

\begin{tabular}{|l||l|}
\hline $\begin{array}{l}\text { Participação das Exportações no } \\
\text { Volume de Vendas Totais Anuais }\end{array}$ & $\mathrm{n}$ \\
\hline \hline Até $25 \%$ & 1 \\
\hline \hline De $25 \%$ a $50 \%$ & 2 \\
\hline \hline De $50 \%$ a $75 \%$ & 3 \\
\hline \hline De $75 \%$ a $100 \%$ & 4 \\
\hline
\end{tabular}

Figura 21: Matriz de Correlação Tempo de Experiência x Volume de Exportação

\begin{tabular}{|c||c|c||}
\hline Matriz de Correlação & $\begin{array}{c}\text { Tempo de } \\
\text { Experiência }\end{array}$ & $\begin{array}{c}\text { Volume de } \\
\text { Exportação }\end{array}$ \\
\hline Tempo de Experiência & 1 & 0,2525868 \\
\hline Volume de Exportação & 0,2525868 & 1 \\
\hline
\end{tabular}

O resultado da Matriz de Correlação (Figura 21) mostra que há uma fraca correlação positiva entre o tempo de experiência com exportações e o volume exportado, considerando todas as empresas respondentes da pesquisa.

\subsubsection{Tempo de Experiência x Quantidade de Mercados de Atuação}

Esta análise considerou a experiência com exportação e a quantidade de mercados que a empresa atua. $\mathrm{O}$ resultado apresentado (Figura 22) mostra uma forte correlação positiva entre as duas variáveis. 
Figura 22: Matriz de Correlação Tempo de Experiência x Quantidade de Mercados

\begin{tabular}{|ll|r|r|}
\hline & & & $\begin{array}{c}\text { Numero de } \\
\text { mercados } \\
\text { que atua }\end{array}$ \\
\hline ANOSEXP & Pearson Correlation & 1,000 &, $627^{*}$ \\
& Sig. (2-tailed) &, &, 000 \\
& $\mathrm{~N}$ & 39 & 39 \\
\hline Numero de & Pearson Correlation &, $627^{* *}$ & 1,000 \\
mercados que atua & Sig. (2-tailed) &, 000 &, \\
& $\mathrm{~N}$ & 39 & 39 \\
\hline
\end{tabular}

${ }^{* *}$. Correlation is significant at the 0.01 level (2-tailed).

Os resultados das Figuras 21 e 22 mostraram que o tempo de experiência tem correlação maior com a quantidade de mercados do que com o volume exportado. Porém, este resultado pode ser mais bem explorado, investigando se as empresas que comprometem maior volume das vendas com exportação, valorizam mais as informações.

\subsubsection{Análise da diferença entre grupos}

Feitas as análises gerais, nos itens anteriores, de uso das informações para atuação no mercado internacional, cabe questionar se as empresas pesquisadas diferem no uso das informações de acordo com as diferentes características de seu perfil.

Para verificar a aplicabilidade do modelo Uppsala, discutido no Capítulo 2, que mostrou que os investimentos em mercado externo crescem a medida que se adquire experiência, as empresas foram agrupadas de acordo com o seguinte critério:

\section{$\underline{\text { Representatividade da Exportacão }}$}

Grupo 1: Empresas que exportam até $25 \%$ do Volume Total Anual de Vendas (28 respondentes)

Grupo 2: Empresas que exportam de 25\% a 100\% (11 respondentes) 
O objetivo desta divisão é observar as características dos grupos, considerando que as empresas que exportam mais, têm um comportamento diferente das demais empresas. $\mathrm{O}$ modelo Uppsala mostrou, por observação do comportamento de quatro empresas suecas, que o envolvimento com mercado internacional faz com que a empresa adquira mais conhecimento e amplie o mercado de atuação.

A representatividade da exportação, aqui considerada, sugere a hipótese especulativa que à medida que o faturamento com exportação cresce, as empresas irão valorizar mais as informações. Para verificar esta hipótese, utilizou-se a Análise de Variância (ANOVA).

O objetivo da análise de variância é verificar se as médias amostrais são diferentes entre si. As respostas são obtidas a partir da análise da variância entre os grupos e dentro dos grupos, cujo resultado mostra que, quanto maior for a variabilidade, maior a diferença entre as médias. Para a análise ANOVA, consideraram-se relevantes as diferenças que apresentaram nível de significância abaixo de $10 \%$, tendo em vista a quantidade de questionários respondidos (39).

\subsubsection{Análise das informações utilizadas}

Primeiramente foram colocadas todas as variáveis na tabela ANOVA (Anexo 8.4.1), cujos resultados com significância abaixo de $10 \%$ foram:

$1^{\mathrm{o}}$. Concorrentes internacionais que atuam no mercado alvo

$2^{\circ}$. Estimativa de demanda do produto no mercado alvo 
$3^{\circ}$. Preço praticado pelos concorrentes

$4^{\circ}$. Assinatura de serviços de informação.

$5^{\circ}$. Os clientes nos enviam as informações necessárias

Com base no resultado da tabela ANOVA do Anexo 8.4.1., foi utilizada a Análise Descritiva (Anexo 8.4.2.) para verificar a significância entre os grupos. Os resultados mostraram que as variáveis analisadas, apresentam significância maior no grupo que exporta acima de $25 \%$ de seu faturamento. Este resultado mostra que as informações competitivas é que apresentaram diferenças significativas. Porém, verifica-se que a quinta variável: "Os clientes nos enviam as informações necessárias" poderia ser considerada com maior significância no grupo que exporta até $25 \%$. Este resultado revela que, independente do comprometimento com as vendas no mercado internacional, é um dado comum entre as empresas exportadoras da região.

Também cabe questionar se a amostra utilizada realmente é representativa do comportamento exportador, tendo em vista que no grupo de 22 variáveis, que representam as informações para atuação no mercado internacional, apenas 5 variáveis apresentaram significância estatística.

\subsubsection{Análise dos Mercados de Atuação}

Para avaliar a diferença entre os grupos, foram colocadas todas as variáveis referentes aos mercados de atuação em uma tabela ANOVA (Anexo 8.4.3), cujos resultados com significância abaixo de $10 \%$ estão aqui representados:

$1^{\circ}$. União Européia 
$2^{\circ}$. Estados Unidos e Canadá

$3^{\circ}$. China

$4^{\text {o. }}$ Ásia, exceto China.

$5^{\circ}$. Oriente Médio

O resultado da tabela ANOVA (Anexo 8.4.3.) foi submetido a Análise Descritiva (Anexo 8.4.4.) para verificar a significância entre os grupos. Os resultados mostraram que as variáveis analisadas, apresentam significância maior no grupo que exporta acima de $25 \%$ de seu faturamento. Este resultado mostra que os mercados mais distantes e com maiores exigências para entrada de produtos importados apresentaram diferenças significativas.

\subsubsection{Análise do Perfil de Atuação}

As variáveis referentes ao perfil de atuação foram em uma tabela ANOVA (Anexo 8.4.5), cujos resultados com significância abaixo de $10 \%$ estão aqui representados:

$1^{\circ}$. Exportação Direta

$2^{\circ}$. Exportação por Agentes Independentes

$3^{\circ}$. Empresa busca novos mercados

Com base no resultado da tabela ANOVA do Anexo 8.4.5., foi utilizada a Análise Descritiva (Anexo 8.4.6.) para verificar a significância entre os grupos. Os resultados mostraram que a Exportação Direta apresenta maior significância no grupo que exporta até $25 \%$ de seu faturamento total anual. O grupo que exporta acima de $25 \%$ de seu faturamento apresenta significância maior na "Exportação por Agentes Independentes" e na "Busca de Novo Mercados”. Este resultado mostra que quanto maior a participação no volume total de 
vendas anuais, as empresas tendem a diversificar mais a forma de atuação nos mercados internacionais.

Cabe aqui, comparar este resultado com o que foi abordado no Capítulo 2, quanto ao processo de inserção internacional. Nesse capítulo, os conceitos do desenvolvimento exportador, explorados por Bilkey e Tesar (1977), Cavusgil (1980) e Johanson e Wildersheim (1975), mostraram que à medida que se desenvolve a inserção internacional, a empresa tende a sofisticar seu perfil de atuação. Assim, as empresas podem iniciar o processo de inserção internacional com exportações esporádicas até atingir a instalação de unidade produtiva no exterior. Durante este processo, as empresas utilizam agentes independentes bem como, ao se tornarem experientes na exportação para países vizinhos, exploram a exportação para países distantes e diferentes culturalmente.

Para explorar mais este resultado, buscou-se analisar apenas o grupo que busca novos mercados e as informações utilizadas. O resultado demonstrado no Gráfico 16 indicou que $55 \%$ das empresas buscam constantemente novos mercados, enquanto que $45 \%$ são procuradas pelos clientes.

\subsubsection{Análise das empresas que buscam novos mercados}

\section{Análise 1: Informações Utilizadas}

Foram selecionadas as empresas que apontaram que buscam novos mercados e as respostas do grupo de informações utilizadas foram colocadas na tabela ANOVA (Anexo 8.4.7), considerando o critério: 


\section{Grupo que busca novos mercados x Informações Utilizadas}

0: Busca Novos Mercados

1: Não busca novos mercados

Os resultados com significância abaixo de 10\% foram:

1. Religião do país alvo

2. Renda Per Capita

3. Volume de Reservas Internacionais

4. Produto Interno Bruto

5. Estabilidade Política

6. Concorrentes Internacionais que atuam no mercado alvo

7. Custos Logísticos para seu produto.

Com base no resultado da tabela ANOVA do Anexo 8.4.7., foi utilizada a Análise Descritiva (Anexo 8.4.8) para verificar a significância entre os grupos. Os resultados mostraram que o grupo que busca novos mercados valoriza mais as informações do ambiente de negócios internacionais, representado pelas informações macroeconômicas.

\section{Análise 2: Mercados de Atuação}

As respostas do grupo que busca novos mercados, referente aos mercados de atuação foram colocadas na tabela ANOVA (Anexo 8.4.9). Os resultados com significância abaixo de $10 \%$ foram:

$1^{\circ}$. América Latina, exceto Mercosul 
$2^{\circ}$. União Européia

$2^{\circ}$. Estados Unidos e Canadá

$3^{\circ}$. China

$4^{\mathrm{o}}$. Ásia, exceto China.

$5^{\circ}$. Oriente Médio

Com base no resultado da tabela ANOVA do Anexo 8.4.9., foi utilizada a Análise Descritiva (Anexo 8.4.10). Os resultados mostraram que o grupo que busca novos mercados atua mais na China, Ásia e Oriente Médio. Assim como o resultado do item 4.4.3.2., que analisa os mercados de atuação do grupo que exporta mais de $25 \%$ do faturamento total anual, as empresas que buscam novos mercados também atuam em países mais distantes e com maiores exigências para entrada de produtos importados, com maior significância nos países orientais.

\section{Análise 3: Tempo de Atuação}

As respostas do grupo que busca novos mercados, referente ao tempo de atuação foram colocadas na tabela ANOVA (Anexo 8.4.11). O resultado apontou significância de 5,8\%. Este resultado foi submetido à Análise Descritiva (Anexo 8.4.12), confirmando que o grupo que atua há mais tempo, busca constantemente novos mercados.

\subsubsection{Análise do impacto da experiência com exportação no uso das informações}

Esta análise busca uma comparação do tempo de atuação no mercado internacional com o uso das informações. O objetivo desta análise é verificar se a experiência no mercado 
internacional reflete no uso mais das informações. Para esta análise, calculou-se o tempo médio de atuação no mercado internacional das empresas respondentes, cujo resultado foi de 9,4 anos. A variável tempo de experiência com exportações foi normalizada, criando-se o histograma demonstrado na Figura 23 a seguir.

Figura 23: Histograma: Número de Anos que a empresa exporta

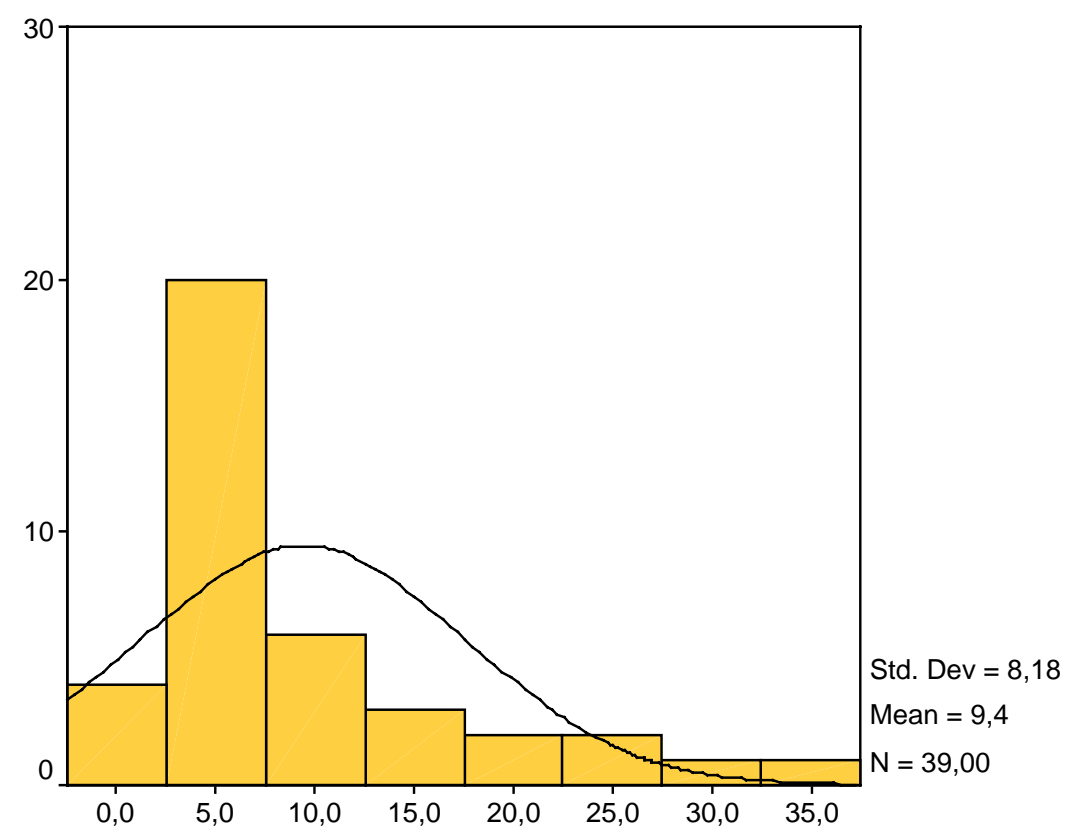

Numero de anos que a empresa exporta

Como hipótese especulativa, sugeriu-se que as empresas que exportam há mais de 9,4 anos têm mais experiência do que as empresas que exportam há menos tempo. Para analisar os dados utilizou-se o Zscore com um desvio padrão (Anexo 8.4.13). Considerou-se, então, 
que as empresas com Zscore maior que zero estão no grupo que exporta mais do que a média amostral, resultando em:

$$
\begin{aligned}
& 1 \text { - Empresas que exportam abaixo do tempo médio (26 empresas) } \\
& 2 \text { - Empresas que exportam acima do tempo médio (13 empresas) }
\end{aligned}
$$

Utilizando-se a Análise de Variância (ANOVA), os dois grupos foram avaliados com as variáveis de informações utilizadas, considerando como variável independente quem exporta acima do tempo médio de 9,4 anos, e as variáveis dependentes:

1- Informações Utilizadas

2- Fontes de Informação

3- Mercados de Atuação

4- Perfil de Atuação

Considerando significância $>0,10$, os resultados não apresentaram significância, o que conclui que o tempo de atuação não influencia nas variáveis analisadas. O perfil das empresas da região, demonstrado no Gráfico 12, revela que $18,4 \%$ das empresas exportam há menos de um ano e 31,6\%, entre 1 e 5 anos, totalizando $50 \%$ da amostra. Assim sendo, o resultado desta análise mostrou que as empresas mais jovens se mostram mais ativas na busca de informações do que as empresas que atuam há mais tempo no mercado internacional.

A seguir, são apresentadas as principais conclusões deste trabalho (Quadro 19). 
Quadro 19: Quadro Resumo das Conclusões do Trabalho

\section{Principais Conclusões do Trabalho}

Informações utilizadas pelas empresas para atuação no mercado internacional

\begin{tabular}{|c|c|c|c|}
\hline \multicolumn{2}{|c|}{ Informações Gerais sobre o País Alvo } & \multicolumn{2}{|c|}{ Informações sobre o Mercado Alvo } \\
\hline NÃO USA & USA & NÃO USA & $\overline{\text { USA }}$ \\
\hline $\begin{array}{c}\text { Religião } \\
\text { Volume de Reservas } \\
\text { Internacionais } \\
\text { Taxa de Desemprego } \\
\text { Renda Per Capita }\end{array}$ & $\begin{array}{c}\text { Idioma } \\
\text { Taxa de conversão da } \\
\text { moeda } \\
\text { Estabilidade Política } \\
\text { Acordos } \\
\text { Internacionais }\end{array}$ & $\begin{array}{l}\text { Custos Logísticos } \\
\text { Existência de } \\
\text { Fabricantes } \\
\text { Procedimentos para } \\
\text { Importação } \\
\text { Impostos incidentes } \\
\text { sobre o produto }\end{array}$ & $\begin{array}{c}\text { Capacidade de } \\
\text { Pagamento dos } \\
\text { Compradores } \\
\text { Preço dos } \\
\text { concorrentes } \\
\text { internacionais } \\
\text { Disponibilidade de } \\
\text { Transporte } \\
\text { Estimativa de } \\
\text { Demanda }\end{array}$ \\
\hline \multicolumn{4}{|c|}{ Fontes de Informação } \\
\hline & Obtidas nas relaç & s com os clientes & \\
\hline
\end{tabular}




\begin{tabular}{|c|c|}
\hline & Feiras Internacionais \\
& Publicações Especializadas \\
\hline \multicolumn{2}{|c|}{ Formas de Atuação no mercado internacional } \\
\hline \multicolumn{2}{|c|}{ Exportação direta } \\
\hline \multicolumn{2}{|c|}{ Experiência Internacional } \\
\hline Maior envolvimento no mercado internacional \\
\hline Influencia muito na diversificação de mercados e pouco no volume de exportação \\
\hline Não influencia no uso das informações & Atuação em mercados mais exigentes \\
Não tem relação com o tempo de atuação no & Diversificação na forma de atuação \\
mercado internacional & Busca constante de novos mercados \\
\hline
\end{tabular}

\section{Conclusões e Considerações Finais}

Este estudo tem como intuito identificar as informações consideradas importantes, utilizadas pelas empresas exportadoras de Ribeirão Preto e região, em sua atuação no mercado internacional.

Dos cinco objetivos propostos nesta pesquisa, o primeiro consistiu na identificação das informações sobre mercados internacionais utilizadas pelas empresas atuar no mercado internacional. Os modelos apresentados no referencial teórico do Capítulo 2 enfatizaram a necessidade de informações em nível interno do país, do produto, do mercado e do ambiente de negócios internacionais, representado pelas informações macroeconômicas. Com o resultado da pesquisa, verificou-se que as informações mais utilizadas estão diretamente ligadas ao mercado alvo, com ênfase nas informações ligadas a oferta/demanda do produto, e pouco se utiliza as informações do ambiente em que está inserido o país com o qual se negocia. 
O segundo objetivo foi a avaliação da freqüência de uso dos diversos tipos de informação. As informações mais citadas pelos respondentes da pesquisa, como utilizadas, são as questões ligadas a capacidade de pagamento dos compradores, exigências, normas e benefícios fiscais para o produto exportado. Em outro extremo, estão as informações de mercado relacionadas à existência de fabricantes no mercado alvo, bem como custos logísticos para o transporte do produto, com pouco ou nenhum uso.

Com relação às informações gerais, considerando o ambiente de negócios, a principal informação citada foi o idioma que o país alvo utiliza nas transações internacionais, seguida pela existência de acordos comerciais com o Brasil. Ainda foram citadas com nenhum ou pouco uso, pela maioria das empresas pesquisadas, as informações referentes à religião, seguidas pelas informações macroeconômicas inflação, PIB, taxa de desemprego, renda per capita e volume de reservas internacionais. Estas respostas indicam que as empresas exportadoras da região de Ribeirão Preto ainda não dimensionam a importância das informações gerais como reflexo no ambiente internacional de negócios. Um indicativo importante deste dimensionamento é a informação sobre a existência de benefícios fiscais para o produto exportado que foi citada por $76,3 \%$ das empresas como "usa sempre" e "usa muito”. Esta informação está diretamente associada à informação da Tabela 15 - Existência de Acordos Comerciais com o Brasil. Como foram expostos no Capítulo 1 (Tabela 1), os acordos comerciais proporcionam aos países signatários, redução dos impostos incidentes para os produtos negociados.

O terceiro objetivo foi a investigação das fontes de informação utilizadas pelas empresas exportadoras. Como resultado, 95\% das empresas responderam que os clientes 
enviam as informações necessárias. Seguido as este resultado, outras fontes mais citadas pelos respondentes foram as feiras internacionais e publicações especializadas. A fonte menos citada foi que a empresa contrata serviços de pesquisa para o mercado alvo. Este resultado revela que as empresas pesquisadas não atuam diretamente na busca de informações, criando um sistema próprio de entendimento de mercado, limitando-se a utilizar as informações fornecidas pelo comprador do produto.

O quarto objetivo visou à identificação dos perfis de ação das empresas na exportação. O resultado revelou que a grande parte das empresas exporta diretamente ou utilizam distribuidores próprios no exterior. No entanto, quase metade das empresas respondeu que a empresa não busca novos mercados, pois os clientes as procuram. Com este resultado aliado ao resultado do objetivo anterior, de que as informações são enviadas pelo próprio cliente, denota, ainda, um perfil passivo na atividade exportadora.

O quinto objetivo buscou analisar os dados obtidos na pesquisa com técnicas estatísticas descritivas de correlação e análise de variância. Os resultados evidenciaram que a experiência internacional influencia muito na diversificação de mercados e tem fraca correlação positiva com o volume de exportação. Verificou-se também que o maior envolvimento no mercado internacional não tem relação com o tempo de atuação e não influencia no uso das informações, quando comparado com o envolvimento das empresas que exportam até $25 \%$ de seu faturamento. Por outro lado, as empresas mais envolvidas com exportação atuam em mercados mais exigentes, diversificam sua forma de atuação e buscam constantemente novos mercados. 


\section{Contribuições e Recomendações para Pesquisas Futuras}

Este trabalho foi realizado, buscando a identificação das informações utilizadas por empresas exportadoras da região de Ribeirão Preto na atividade exportadora. As principais contribuições deste trabalham permitiram entender primeiramente como estas empresas atuam no mercado internacional. Ainda que a amostra seja composta por empresas com pequeno volume de exportações em relação às vendas totais, observa-se que a atuação é muito centrada em poucos mercados.

Esta pesquisa, como um estudo piloto, buscou a aplicação dos principais modelos de inteligência de mercados internacionais já aplicados em outros países. É importante que esta pesquisa seja realizada em outras regiões, tanto do estado de São Paulo, quanto no país, pois a amostra pode ser considerada pequena em relação a quantidade de empresas brasileiras que atuam no mercado internacional. 
Com base no que foi levantado na pesquisa de campo, as empresas exportadoras da região utilizam mais informações ligadas ao mercado do que propriamente o ambiente em que estão inseridas. Assim sendo, novos estudos podem se beneficiar da metodologia de pesquisa desenvolvida neste trabalho, tais como:

- Estudo comparativo das informações utilizadas para cada país onde as empresas atuam.

- Pesquisa dos obstáculos à obtenção de informação sobre os países alvo.

- Estudos setoriais do comportamento exportador das empresas brasileiras.

Estas sugestões não esgotam as possibilidades de estudos e análises necessárias para o aprimoramento da atuação internacional das empresas brasileiras. Mas podem contribuir para criação de caminhos para o entendimento do processo de inserção internacional tendo em vista a relevância para o desenvolvimento do país. 


\section{Referências Bibliográficas}

AAKER, D.A., DAY G. Marketing Research. 2a. Ed. New York: John Wiley \& Sons, 1983.

AMARAL, A.C.R. (Coordenador) Direito do Comércio Internacional: Aspectos Fundamentais. São Paulo: Aduaneiras, 2004.

ANDERSON, D. R. SWEENEY, D. J. WILLIANS, T.A. Estatística Aplicada à Administração e Economia. São Paulo: Pioneira Thomson Learning, 2003.

ANDERSON, V. BOOCOCK, G. GRAHAM, S. An Investigation into the learning needs of managers in internationalizing small and medium-size enterprises. Journal of Small Business and Enterprise Development. Vol. 8 No. 3, 2001 pp 215-232.

ARBIX, G. SALERNO, M.S. DE NEGRI, J.A. Internacionalização gera emprego de qualidade e melhora a competitividade das firmas brasileiras. In: DE NEGRI, J.A. SALERNO, M.S. (org.) Inovações, Padrões Tecnológicos e Desempenho das firmas industriais brasileiras. Brasília: IPEA, 2005.

BARRET, N. I. WILKINSON, I.F. Export Stimulation: A segmentation study of the exporting problems of Australian manufacturing firms. European Journal of Marketing. Vol. 19, No. 2, 1985 pp 53-72.

BNDES. O Desafio das Exportações. Rio de Janeiro: BNDES, 2002.

BHATT, G. D. Organizing knowledge in the knowledge development cycle. Journal of knowledge Management. Vol.4 No. 1 2000. pp 15-26 
BILKEY, W. J. An Attempted Integration of the Literature on the Export Behavior of Firms. Journal of International Business Studies, 9 33-46, 1978.

BRADSHAW, R. BURRIDGE, M. Practices of Successful small and medium-sized exporters: The use of market information. Journal of Small Business and Enterprise Development. Vol 8, No. 3, 2001 pp 267-273.

CABRAL, J.E.O., SILVA JÚNIOR, L.A. Dimensões do Marketing Estratégico, Atitudes e Percepções Gerenciais e Sucesso Exportador das Empresas Cearenses. In: XXVIII Encontro da Associação Nacional de Pós-Graduação e Pesquisa em Administração (ENANPAD), Curitiba, 2004

CAdOGAn, J. DiAmantopoulos, A. MORTANGES, C. A Measure of Export Market Orientation: scale development and cross-cultural validation. Journal of International Business Studies, Washington, v. 30 n. 4, p. 689-707, 1999

CALOF, J. BEAMISH, P. Adapting to foreign markets: explaining internationalization. International Business Review, Vol. 4 No. 2 pp 367-87, 1995

CANONGIA, C. SANTOS, D.A., SANTOS M.M., ZACKIEWICZ, M. Foresight, Inteligência Competitiva e Gestão do Conhecimento: Instrumento para a Gestão da Inovação. Disponível em: <http://www.scielo.br/pdf/gp/v11n2/a09v11n2.pdf> Acesso em 01. Out. 2005.

CARVALHO, D.T. Sistema de Inteligência de Mercados Internacionais: Um estudo Piloto. Faculdade de Economia, administração e Contabilidade de Ribeirão Preto, USP, 2003. (Projeto de Pesquisa para Concurso de Professor Doutor)

CARVALHO, F.A.C. Impact of the Perceived Importance of Information Type on the Perceived Importance of Information Source for Export Market Decision: An empirical Study on Brazilian Exporters. In: XXI Encontro da Associação Nacional de Pós-Graduação e Pesquisa em Administração (ENANPAD), Rio das Pedras, 1999.

CASAROTTO FILHO, N. PIRES, L.H. Redes de Pequenas e Médias Empresas e Desenvolvimento Local: Estratégias para a conquista da competitividade global com base na experiência italiana. 2 ${ }^{a}$. Ed. São Paulo: Atlas, 2001.

CAVUSGIL, S.T. NEVIN, J. Internal determinants of export marketing behavior: an empirical analysis. Journal of Marketing Research, Vol 18 no. 1 pp 114-9, 1981.

CHAUDHRY, S. CRICK, D. Export Information Providers: Are they meeting the needs of SMEs? Marketing Intelligence \& Planning, 1998 pp 141-149

CHETTY, S. CAMPBEL-HUNT, C. Paths to internationalization among small- to mediumsized firms. European Journal of Marketing, Col. 37, No. 56, pp 796-821, 2003.

CRICK, D. CHAUDHRY, S. Small business' motives for exporting. The effect of internalization. Journal of Marketing Practice: Applied Marketing Science. Vol.3 No. 31997 pp 156-170. 
DAVENPORT, T. PRUSAC, L. Working Knowledge. Boston: Harvard Business School Press, 1998.

DAY, G.S. Continuous Learning About Markets. California Management Review. Summer 1994 pp 9-31

DAY, G.S. NEDUNGADI, P. Managerial Representations of Competitive Advantage. Journal of Marketing, Vol. 58 (April 1994) 31-44

DENIS, J.E. DEPELTEAU, D. Market Knowledge, Diversification and Export Expansion. Journal of International Business Studies, Autumn, 1985, pp 77-89

DIAMANTOPOULOS, A. Viewpoint: Export performance measurement: Reflective versus formative indicators. International Marketing Review. Vol. 16, No. 6, 1999 pp 444-457.

DIAMANTOPOULOS, A. SOUCHON, A.L. Measuring Export Information Use: Scale Development and Validation. Journal of Business Research 46, 1-14, 1999

DIAMANTOPOULOS, A. SOUCHON, A.L. DURDEN, G.R. AXINN C. HOLZMULLER, $\mathrm{H}$. Towards an understanding of cross-national similarities and differences in export information utilization: A perceptual mapping approach International Marketing Review. Vol 20. No. 1, 2003 pp 17-43

DIAS, R. RODRIGUES, W. (organizadores). Comércio Exterior: Teoria e Gestão. São Paulo: Atlas, 2004.

DOOLE, I. LOWE R. International Marketing Strategy. 4a. Ed. London: Thomson-Learning, 2004

ESHGHI, A. Attitude-behaviour Inconsistency in Exporting International Marketing Review. Vol. 9 No. 3, 1992 pp 40-61.

FERRAZ FILHO, G. RIBEIRO, F.J. Um Levantamento de atividades relacionadas à atividade exportadora das empresas brasileiras: resultados de pesquisa de campo junto a 460 empresas exportadoras. In: O desafio das Exportações. Rio de Janeiro: BNDES, 2002. Disponível em: < http://www.bndes.gov.br/conhecimento/livro desafio/Relatorio-13.pdff Acesso em 10 jul 2006

GUIMARÃES, E.P. Política de Exportação Brasileira para as Pequenas e Médias Empresas. In: O Desafio das Exportações, Rio de Janeiro: 2002. Disponível em $<$ http://www.bndes.gov.br/conhecimento/publicacoes/catalogo/liv_desafio.asp. Acesso em 10 Abr. 2005.

HAAR, J. ORTIZ-BUONAFINA, M. The Internationalization Process and Marketing Activities: The Case of Brazilian Export Firms. Journal of Business Research 32, 175-181 (1995)

HAIR, J.F.Jr; ANDERSON, R.F. TAHAN, R.L. BLACK, W. Análise Multivariada de Dados. 5 . Ed. Porto Alegre: Bookman, 2005. 
HAVNES, P. Dynamics of Small Business Internationalization - A European panel study. A Thesis submitted for The Degree of Doctor of Philosophy Department of Entrepreneurship University of Stirling, Scotland, Submitted June 1998.

HILL, J. S. World Business - Globalization, Strategy and Analysis. Ohio: Thomson SouthWestern, 2005.

JAFFE, E. D. PASTERNAK, H. An Attitudinal Model to Determine the Export Intention of Non-Exporting, Small Manufactures. International Marketing Review. Vol. 11 No. 3, 1994 pp $17-32$

JAIN, S.C. Marketing Planning \& Strategy. 6a. Ed. Ohio: Thomson, 2000.

JOHANSON, J., VAHLNE J.E. The internationalization process of the firm - a model of knowledge development and increasing foreign market commitments. Journal of Business Studies. Vol 8. pp 23-32 1977.

JOHANSON, J. WIEDERSHEIM-PAUL, F. The internationalization of the firms: A Study of the UK experience. Journal of Management Studies. Vol 12. Autumn, 1975 pp 305-22.

KASTIKEAS, C.S. MORGAN R.E. Differences in perception of exporting problems based on firm size and export market experience. European Journal of Marketing. Vol. 28 No. 5, 1994 pp 17-35.

KEEGAN, W. Marketing Global. 7ª Ed. São Paulo: Prentice Hall, 2005.

KELLEY, W.T. Marketing Intelligence for Top Management Journal of Marketing Vol. 29, Oct. 1965, pp.19-24.

KOTLER, P. Administração de Marketing. 10a . Ed. São Paulo: Prentice Hall, 2000.

KUAZAQUI, E. Marketing Internacional: Como Conquistar Negócios em Mercados Internacionais. São Paulo: Makron, 1999.

LAMBIN, J. Market-driven Management: strategic \& Operational Marketing New York: Palgrave, 2000.

LARSON, R. FARBER, B. Estatística aplicada. 2a. Ed. São Paulo: Prentice Hall, 2004.

LEONIDOU, L.C.; KATSIKEAS, C.S. The Export Development Process: An Integrative Review of Empirical Models. Journal of International Business Studies.3o.Quarter 1996. pag 517-551.

LI, T. CAVUSGIL, S.T. Decomposing the effects of market knowledge competence in new product export: A dimensionality analysis. European Journal of Marketing. Vol . 34 Vol. 1/2, 2000 pp 57-79.

LIMA, E.T. CARVALHO JÚNIOR, M.C. Ações para Acelerar a Expansão das Exportações. Revista do BNDES, Rio de Janeiro, V.7. N. 14, p 253-272, Dez 2000. 
LLOYD-REASON, L. MUGHAN, T. Strategies for internationalization within SMEs: The key role of the owner-manager. Journal of Small Business and Enterprise Development. Vol. 9 N.2 2002 pp 120-129.

MACERA, A.P. URDAN, A.T.Orientação para o Mercado Externo: teste de um modelo no Brasil e sua aplicação a uma amostra de empresas exportadoras brasileiras. In: XXVI Encontro da Associação Nacional de Pós-Graduação e Pesquisa em Administração (ENANPAD), Salvador, 2002.

MACHADO, M.A. O Envolvimento Exportador e a Performance Exportadora: Uma revisão analítica em busca de uma tipologia explanatória para a exportação. In: XXVIII Encontro da Associação Nacional de Pós-Graduação e Pesquisa em Administração (ENANPAD), Curitiba, 2004.

MACKAY, D.B. EASLEY, R. International differences in product perception: a product map analysis. International Marketing Review. Vol. 13 No. 2, 1996, pp. 54-62.

MARCKWALD, R. PUGA, F. Focando a Política de Promoção de Exportações In: O desafio das Exportações. Rio de Janeiro: BNDES, 2002. Disponível em: < http://www.bndes.gov.br/conhecimento/livro desafio/Relatorio-04.pdf 3 Acesso em $10 \mathrm{jul}$ 2006

MINERVINI, N. O Exportador. 4a . Ed. São Paulo: Prentice Hall, 2005.

MINISTÉRIO DO DESENVOLVIMENTO, INDÚSTRIA E COMÉRCIO EXTERIOR. Contém Indicadores e Estatísticas de Comércio Exterior. Disponível em: < http://www.desenvolvimento.gov.br/arquivo/secex/evocomextbrasil/evolucaocebrasileiro.xls Acesso em: 16 ju. 2006

PALACIOS, T.M.G., SOUSA, J.M.M. Estratégias de Marketing Internacional. São Paulo: Atlas, 2004.

PUGA, F.P. Experiências de Apoio às Micro, Pequenas e Médias Empresas nos Estados Unidos, Itália e Taiwan. Rio de Janeiro: BNDES, 2000. (Texto para Discussão 75)

- O Apoio Financeiro às Micro, Pequenas e Médias Empresas na Espanha, no Japão e México. Rio de Janeiro: BNDES. 2000. (Texto para discussão 96)

REID, S.D. The Decision-Maker and Export Entry and Expansion. Journal of International Business Studies, Fall 1981. pp 101-112

RICHARDSON, R. J. Pesquisa social: métodos e técnicas. 3a . Ed. São Paulo: Atlas, 1999.

RICKEY, R.G. MYERS, M.B. An Investigation of Market Information use in Channel Decisions: Antecedents and Outcomes. International Journal of Physical Distribution \& Logistics Management, Vol 31, No. 5, 2001 pp 334-353

SAMIEE, S. WALTERS P.G.P., DUBOIS, F.L. Exporting as an Innovative Behavior: An Empirical Investigation. International Marketing Review. Vol 10. No. 3, 1993, pp. 5-25. 
SERINGHAUS, F.H.R. (1986/87), The role of information assistance in small firms' export involvement, International Small Business Journal, Vol. 5 No.2, pp.26-36.

SERVIÇO BRASILEIRO DE APOIO ÀS MICRO E PEQUENAS EMPRESAS (SEBRAE). Boletim Estatístico de Micro e Pequenas Empresas. Observatório Sebrae $1^{\circ}$. Semestre 2005. Disponível em: <http://www.sebrae.com.br/br/mpe_numeros/> Acesso em 09 Out. 2005.

A Micro e Pequena Empresa no Comércio Exterior - 2a . Parte. Brasília: SEBRAE, Agosto, 1998.

. Desempenho Exportador das Micro e Pequenas Empresas Industriais Brasileiras.

Boletim 2005 (Dados 2004). Disponível em:
$<$ http://www.sebrae.com.br/br/pesquisa_exportacao3/index.asp> Acesso em 09 Out. 2005.

SENGE, P. The fifth discipline. New York: Doubleday, 1990.

SILVA, P.A. ROCHA A. Perception of export barriers to Mercosur by Brazilian Firms. International Marketing Review, Vol. 18 No. 6, 2001, pp 589-610.

SOARES, C.S. Introdução ao Comércio Exterior: Fundamentos Técnicos do Comércio Internacional. São Paulo: Saraiva, 2004.

SOUCHON, A.L. DIAMANTOPOULOS, A. Export information acquisition modes: measure development and validation International Marketing Review, Vol 16 No. 2, 1999 pp 143-168.

TOFTEN, K. The Influence of export information use on export knowledge and performance: Some empirical evidence. Marketing Intelligence \& Planning. Vol 23 No. 2, 2005 pp 200-219

TOFTEN, K. RUSTAD K. Attributes of information quality of export market assistance: an exploratory study. European Journal of Marketing. Vol. 39 no. 5/6, 2005 pp 676-695.

TRIPOLDI, T. et al. Análise da pesquisa social: diretrizes para o uso de pesquisa em serviço social e em ciências sociais. Rio de Janeiro: Francisco Alves, 1975.

VEIGA, P.M. O viés anti-exportador: mais além da política comercial. In: O desafio das Exportações. Rio de Janeiro: BNDES, 2002. Disponível em: < http://www.bndes.gov.br/conhecimento/livro desafio/Relatorio-05.pdf Acesso em $10 \mathrm{jul}$ 2006.

VERWAAL, E. DONKERS, B. Firm Size and Export Intensity: Solving and Empirical Puzzle. Journal of International Business Studies, 33, 4(3o Quarter,2002) pp. 603-613.

WELCH, L.S. LOUSTARINEN, R. Internationalization: evolution of a concept. Journal of General Management, Vol 14 no. 2, pp 34-55, 1988.

WESTHEAD, P. BINKS, M. UCBASARAN, D. WRIGHT, M. Internationalization of SMEs: a research note. Journal of Small Business and Enterprise Development. Vol. 9 No. 1, 2002. pp 38-48 
WHITELOCK, J. Viewpoint: Theories of internationalisation and their impact on market entry. International Marketing Review Vol. 19 No. 4, 2002, pp 342-347

WILLIAMS J.E.M. Export Information use in small and medium-sized industrial companies: An application of Diamantopoulos' and Souchon' scale. International Marketing Review Vol 20 No. 1, 2003 pp 44-66

WOOD, V. R. ROBERTSON, K.R. Evaluating International Markets - The importance of information by industry, by country of destination, and by type of export transaction. International Marketing Review, Vol 17, No. 1, 2000 pp. 34-55.

Strategic Orientation and export success: an empirical study. International Marketing Review. Vol 14 No. 6, 1997 pp. 424-444.

YEOH, Poh-Lin International learning: Antecedents and performance implications among newly internationalizing companies in an exporting context. International Marketing Review. Vol. 21 No.4/5, 2004 pp 511-535.

ZAHRA, S. A. KORRI J.S. YU, J. Cognition and international entrepreneurship: implications for research on international opportunity recognition and exploitation. International Business Review 14 (2005) 129-146.

ZOU S., STAN, The Determinants of Export Performance: A review of the empirical literature between 1987-1997.Internacional Marketing Review. Vol. 15, No. 5, pp 333-356. 
Neste tópico são apresentados:

8.1. Email Convite

8.2. Instrumento de Pesquisa

8.3. Relação das empresas respondentes

8.4 Tabelas 


\subsection{Email Convite}

Prezado Senhor/Senhora

Meu nome é Orliene Maciel Guimarães e sou pesquisadora da Universidade de São Paulo (USP) Campus de Ribeirão Preto. Juntamente com o Prof. Dr. Dirceu Tornavoi de Carvalho, estou realizando pesquisa com empresas exportadoras. O objetivo é analisar as informações e suas fontes, para atuação no mercado internacional.

Peço sua colaboração respondendo as questões que se seguem. Sua contribuição será muito valiosa para a conclusão deste trabalho e nos comprometemos a enviar-lhe os resultados gerados e citar e seu nome e/ou da empresa na dissertação a ser publicada no próximo mês, se for de vosso interesse.

As informações serão tratadas de forma agregada, eliminando qualquer receio quanto à confidencialidade das respostas individuais. 
Para responder, retorne a planilha ao remetente (orliene.maciel@terra.com.br) com as respostas assinaladas nos campos respectivos.

Agrademos antecipadamente sua colaboração.

\subsection{Instrumento de Pesquisa - Questionário}

\begin{tabular}{|c|c|}
\hline \multicolumn{2}{|c|}{ DADOS DA EMPRESA } \\
\hline \multicolumn{2}{|l|}{ Em que ano a empresa foi fundada? } \\
\hline \multicolumn{2}{|c|}{ Qual o principal setor de atuação da empresa? } \\
\hline \multirow{4}{*}{ Qual o número de funcionários? } & Até 10 \\
\hline & de 11 a 40 \\
\hline & de 41 a 200 \\
\hline & Acima de 200 \\
\hline \multirow{4}{*}{ Qual a receita anual com exportações? } & Até US $400 \mathrm{mil}$ \\
\hline & Até US 3,5 milhões \\
\hline & Até US 20 milhões \\
\hline & Acima de US 20 milhões \\
\hline \multirow{5}{*}{$\begin{array}{l}\text { Qual a participação das exportações } \\
\text { no volume de vendas totais anuais? }\end{array}$} & Até $25 \%$ \\
\hline & de $25 \%$ a $50 \%$ \\
\hline & de $50 \%$ a $75 \%$ \\
\hline & de $75 \%$ a $100 \%$ \\
\hline & $100 \%$ \\
\hline \multicolumn{2}{|l|}{$\begin{array}{l}\text { Qual foi o primeiro ano que a empresa } \\
\text { exportou? }\end{array}$} \\
\hline \multicolumn{2}{|l|}{$\begin{array}{l}\text { Qual foi o primeiro país que a empresa } \\
\text { exportou? }\end{array}$} \\
\hline \multicolumn{2}{|c|}{ MERCADOS DE ATUAÇÃO } \\
\hline \multirow{5}{*}{$\begin{array}{l}\text { Para quais mercados a empresa } \\
\text { exporta? }\end{array}$} & $\begin{array}{l}\text { MERCOSUL - Argentina, Uruguai e } \\
\text { Paraguai }\end{array}$ \\
\hline & Demais países latino americanos \\
\hline & União Européia \\
\hline & EUA + Canadá \\
\hline & China \\
\hline
\end{tabular}




\begin{tabular}{|c|c|}
\hline & Demais países asiáticos \\
\hline & África \\
\hline & Oriente Médio \\
\hline & Outros \\
\hline \multicolumn{2}{|c|}{ PERFIL DE ATUAÇÃO } \\
\hline \multirow{6}{*}{$\begin{array}{l}\text { Como a empresa atua no mercado } \\
\text { internacional? }\end{array}$} & Exporta diretamente \\
\hline & Exporta para distribuidores próprios \\
\hline & Utiliza agentes independentes no exterior \\
\hline & Utiliza "Exporta Fácil" \\
\hline & $\begin{array}{l}\text { A empresa busca constantemente novos } \\
\text { mercados }\end{array}$ \\
\hline & $\begin{array}{l}\text { Não buscamos novos mercados, os clientes } \\
\text { nos procuram }\end{array}$ \\
\hline
\end{tabular}

\section{INFORMAÇÕES SOBRE OS PAÍSES PARA OS QUAIS A EMPRESA EXPORTA}

Questão: Ao exportar para um país, quais informações são utilizadas?

\begin{tabular}{|l|c|c|c|c|}
\hline \multicolumn{1}{|c|}{ Informações gerais sobre o país alvo } & $\begin{array}{c}\text { Não } \\
\text { usa }\end{array}$ & $\begin{array}{c}\text { Usa } \\
\text { pouco }\end{array}$ & $\begin{array}{c}\text { Usa } \\
\text { muito }\end{array}$ & $\begin{array}{c}\text { Usa } \\
\text { Sempre }\end{array}$ \\
\hline Idioma utilizado nas transações internacionais & & & & \\
\hline Religião & & & & \\
\hline Inflação & & & & \\
\hline Taxa de conversão da moeda do país alvo x Dólar EUA & & & & \\
\hline Renda per capita & & & & \\
\hline Volume de Reservas Internacionais & & & & \\
\hline PIB - Produto Interno Bruto & & & & \\
\hline Taxa de desemprego & & & & \\
\hline Estabilidade Política & & & & \\
\hline Relações diplomáticas com o Brasil & & & & \\
\hline Existência de Acordos Comerciais com o Brasil & Não & Usa & Usa & Usa \\
\hline & pouco & muito & Sempre \\
\hline Concorrentes internacionais que atuam no mercado & & & & \\
\hline Existência de fabricantes & & & & \\
\hline Estimativa de demanda do produto & & & & \\
\hline Capacidade de pagamento dos compradores & & & & \\
\hline Preço praticado pelos concorrentes & & & & \\
\hline Impostos incidentes sobre o seu produto & & & & \\
\hline Benefícios fiscais para o seu produto & & & & \\
\hline Exigências e normas para o seu produto & & & & \\
\hline Custos logísticos no país alvo & & & & \\
\hline Disponibilidade de transporte para o país alvo & & & & \\
\hline Procedimentos burocráticos para importação & & & \\
\hline
\end{tabular}




\begin{tabular}{|l|l|c|c|c|}
\hline \multicolumn{1}{|c|}{ Fontes de Informação sobre o país alvo } & $\begin{array}{c}\text { Não } \\
\text { usa }\end{array}$ & $\begin{array}{c}\text { Usa } \\
\text { pouco }\end{array}$ & $\begin{array}{c}\text { Usa } \\
\text { muito }\end{array}$ & $\begin{array}{c}\text { Usa } \\
\text { Sempre }\end{array}$ \\
\hline Embaixadas/Consulados brasileiros & & & & \\
\hline Embaixadas/Consulados estrangeiros & & & & \\
\hline Câmaras de Comércio & & & & \\
\hline Assinatura de serviços de informações & & & & \\
\hline Publicações especializadas & & & & \\
\hline A empresa tem um sistema próprio de pesquisa & & & \\
\hline A empresa contrata serviços de pesquisa & & & & \\
\hline Feiras Internacionais nos fornecem as informações & & & & \\
\hline Os clientes nos enviam as informações necessárias & & & \\
\hline Outras Fontes: & & & \\
\hline
\end{tabular}

\section{INFORMAÇÕES SOBRE O RESPONDENTE}

\begin{tabular}{|l|l|l|}
\hline \multirow{4}{*}{ Qual o seu cargo na empresa? } & Dono/Proprietário \\
\cline { 2 - 3 } & & Diretor/Presidente \\
\cline { 2 - 3 } & & Supervisor/Coordenador/Gerente \\
\cline { 2 - 3 } & & Analista \\
\cline { 2 - 3 } & & Assessor contratado \\
\cline { 2 - 3 } & & Representante \\
\cline { 2 - 3 } & & Outros \\
\hline \multirow{4}{*}{ Qual área da empresa você trabalha? } & Marketing/Comercial \\
\cline { 2 - 3 } & & Operações/Produção \\
\cline { 2 - 3 } & & Finanças \\
\hline & & Contabilidade \\
\cline { 2 - 3 } & Recursos Humanos \\
\hline Qual sua formação educacional? & \\
\hline Há quanto tempo atua na área internacional? & \multicolumn{2}{|l}{} \\
\hline Você já fez cursos específicos da área internacional? & \\
\hline
\end{tabular}


8.3 Relação das empresas exportadoras da região

\begin{tabular}{|c|l|l|}
\hline SEQ & \multicolumn{1}{|c|}{ EMPRESA } & \multicolumn{1}{|c|}{ CIDADE } \\
\hline 1 & VERSI CRIVELENTI FERRERO & ALTINOPOLIS \\
\hline 2 & AGROPLANTA INDÚSTRIAS QUIMICAS LTDA & BATATAIS \\
\hline 3 & BATATAIS PAVAN COMPON AUTOM LTDA IMPORT & BATATAIS \\
\hline 4 & FUNDICAO BATATAIS LTDA & BATATAIS \\
\hline 5 & IMPLEMENTOS AGRICOLAS MARISPAN LTDA & BATATAIS \\
\hline 6 & JUSTINO DE MORAIS IRMAOS S/A & BATATAIS \\
\hline 7 & PLURINOX INDÚSTRIA E COMERCIO LTDA & BATATAIS \\
\hline 8 & VOBER IND E COM LTDA & BATATAIS \\
\hline 9 & J.F. INDÚSTRIA DE COSMETICOS LTDA & BRODOWSKI \\
\hline 10 & REVEST-BRAS INDÚSTRIA E COMERCIO LTDA. & BRODOWSKI \\
\hline 11 & CINAP COMERCIO E IND DE AUTO PECAS LTDA & CRAVINHOS \\
\hline 12 & CONIMEL EMPRESA DE MATERIAL ELETRICO LTDA & CRAVINHOS \\
\hline 13 & FERTILANCE MAQUINAS AGRICOLAS LTDA & CRAVINHOS \\
\hline 14 & J.V. EQUIPAM MEDICOS E ODONTOL LTDA EPP & CRAVINHOS \\
\hline 15 & LUCYN COM E REPRES DE MAQUINAS LTDA & CRAVINHOS \\
\hline 16 & OURO FINO AGROSCIENCES LTDA & CRAVINHOS \\
\hline 17 & OURO FINO SAUDE ANIMAL LTDA & CRAVINHOS \\
\hline 18 & PALETRANS EQUIPAMENTOS LTDA & CRAVINHOS \\
\hline 19 & PRAMAC BRASIL EQUIPAMENTOS LTDA & CRAVINHOS \\
\hline 20 & RENK ZANINI S A EQUIPAMENTOS INDUSTRIAIS & CRASOS \\
\hline
\end{tabular}




\begin{tabular}{|c|c|c|}
\hline 21 & |TES TECNOLOGIA SISTEMAS E COMERCIO LTDA & CRAVINHOS \\
\hline 22 & A ULDERIGO ROSSI IND DE MAQS GRAFICAS LTDA & RIBEIRAO PRETO \\
\hline 23 & AGMAQ EQUIP E MONTAGENS INDS LTDA EPP & RIBEIRAO PRETO \\
\hline 24 & AGROSYSTEM COM, IMPORT E EXPORT LTDA & RIBEIRAO PRETO \\
\hline 25 & AJUBA INDÚSTRIA E COMERCIO LTDA. & RIBEIRAO PRETO \\
\hline 26 & ANTICORROSIVA DO BRASIL LTDA & RIBEIRAO PRETO \\
\hline 27 & ARNALDO DE ALMEIDA PRADO FILHO & RIBEIRAO PRETO \\
\hline 28 & BETUNEL INDÚSTRIA E COMERCIO LTDA. & RIBEIRAO PRETO \\
\hline 29 & BME SISTEMAS DE ENERGIA LTDA & RIBEIRAO PRETO \\
\hline 30 & BRANDY INDÚSTRIA E COMERCIO LTDA. & RIBEIRAO PRETO \\
\hline SEQ & EMPRESA & CIDADE \\
\hline 31 & BRASPOR RIBEIRAO LTDA & RIBEIRAO PRETO \\
\hline 32 & CARNAUBA EXPORTACAO E IMPORTACAO LTDA & RIBEIRAO PRETO \\
\hline 33 & CENTRO TECNICO RONCAR LTDA & RIBEIRAO PRETO \\
\hline 34 & CESAR N. ALFONZO COML EXPORT E IMPORT LT & RIBEIRAO PRETO \\
\hline 35 & CIPAMED EMBAL MEDICO-HOSPIT LTDA - EPP & RIBEIRAO PRETO \\
\hline 36 & COMEGA INDÚSTRIA DE TUBOS LTDA. & RIBEIRAO PRETO \\
\hline 37 & COMPANHIA DE BEBIDAS IPIRANGA & RIBEIRAO PRETO \\
\hline 38 & CONSOLI \& CIA LTDA. - EPP & RIBEIRAO PRETO \\
\hline 39 & CORDOBA INDUSTRIAL LTDA & RIBEIRAO PRETO \\
\hline 40 & CRYSTALSEV COM E REPRESENTACAO LTDA & RIBEIRAO PRETO \\
\hline 41 & DABI ATLANTE INDS MEDICO ODONTOL LTDA & RIBEIRAO PRETO \\
\hline 42 & DEL REI INDÚSTRIA DE ARTEF DE LATEX LTDA & RIBEIRAO PRETO \\
\hline 43 & DENT-FLEX INDÚSTRIA E COMERCIO LTDA & RIBEIRAO PRETO \\
\hline 44 & DENTSCLER IND DE AP ODONTOLOGICOS LTDA & RIBEIRAO PRETO \\
\hline 45 & DI MARIOTTI INDÚSTRIA DE CALCADOS LTDA & RIBEIRAO PRETO \\
\hline 46 & DINAGRO AGRO PECUARIA LTDA & RIBEIRAO PRETO \\
\hline 47 & DINATEC PECAS E SERVICOS LTDA & RIBEIRAO PRETO \\
\hline 48 & DM TECH PRODUTOS ELETRO - ELETRONICOS LTDA. & RIBEIRAO PRETO \\
\hline 49 & D-X INDÚSTRIA, COMERCIO E EXPORTACAO LTDA & RIBEIRAO PRETO \\
\hline 50 & EDITORA COC EMPREEND CULTURAIS LTDA & RIBEIRAO PRETO \\
\hline 51 & EXPANSAO COMERCIO INTERNACIONAL LTDA & RIBEIRAO PRETO \\
\hline 52 & FERRAZ MAQUINAS E ENGENHARIA LTDA & RIBEIRAO PRETO \\
\hline
\end{tabular}




\begin{tabular}{|c|c|c|}
\hline 53 & FOOD AND MACHINES EXPORT E IMPORT LTDA & RIBEIRAO PRETO \\
\hline 54 & FUND DE APOIO AO ENSINO PESQ E AS HCFMRPUSP & RIBEIRAO PRETO \\
\hline 55 & GIGANTE RECEM NASCIDO IND COM E REP LTDA & RIBEIRAO PRETO \\
\hline 56 & GIL EQUIPAMENTOS INDUSTRIAIS LIMITADA & RIBEIRAO PRETO \\
\hline 57 & GNATUS EQUIP MEDICO ODONTOLOGICOS LTDA & RIBEIRAO PRETO \\
\hline 58 & GNATUS INTERNATIONAL LTDA & RIBEIRAO PRETO \\
\hline 59 & GUARIM EQUIP DIESEL E FABRIC DE MAQUINAS IND & RIBEIRAO PRETO \\
\hline 60 & GUTTEMBERG CUNHA MUNIZ EPP & RIBEIRAO PRETO \\
\hline 61 & HIDROVACHEK LTDA & RIBEIRAO PRETO \\
\hline 62 & INDÚSTRIA DE PROD ALIMENTICIOS CORY LTDA & RIBEIRAO PRETO \\
\hline SEQ & EMPRESA & CIDADE \\
\hline 63 & IND E COM DE CALCADOS RIO MODINHA LTDA & RIBEIRAO PRETO \\
\hline 64 & INDÚSTRIAS REUNIDAS FRATESCHI LTDA-EPP & RIBEIRAO PRETO \\
\hline 65 & INTERMERC COMERCIO INTERNACIONAL LTDA & RIBEIRAO PRETO \\
\hline 66 & INTERUNION COMERCIO INTERNACIONAL LTDA & RIBEIRAO PRETO \\
\hline 67 & IR CONSULTORIA PROJETOS E MONTAGENS LTDA & RIBEIRAO PRETO \\
\hline 68 & IRBO-INDÚSTRIA DE ARTEF DE BORRACHA LTDA & RIBEIRAO PRETO \\
\hline 69 & JP INDÚSTRIA FARMACEUTICA S/A & RIBEIRAO PRETO \\
\hline 70 & LAVORWASH BRASIL INDL E COML LTDA & RIBEIRAO PRETO \\
\hline 71 & LEANDRO MARIANO FRANCA & RIBEIRAO PRETO \\
\hline 72 & MARANGATU SEMENTES LTDA & RIBEIRAO PRETO \\
\hline 73 & METALCURY FUNDICAO INDUSTRIAL LTDA. & RIBEIRAO PRETO \\
\hline 74 & MICRODENT AP ODONTOLOGICOS LTDA - EPP & RIBEIRAO PRETO \\
\hline 75 & MICROEM PRODUTOS MEDICOS LTDA & RIBEIRAO PRETO \\
\hline 76 & MINERADORA BKS LIMITADA & RIBEIRAO PRETO \\
\hline 77 & NAVY ATRAM - IND E COM DE EQUIP ODONT & RIBEIRAO PRETO \\
\hline 78 & NESTLE BRASIL LTDA. & RIBEIRAO PRETO \\
\hline 79 & NETAFIM BRASIL SIST E EQUIP DE IRRIGACAO LTD & RIBEIRAO PRETO \\
\hline 80 & ODONTICS INDÚSTRIA E COMERCIO LTDA - EPP & RIBEIRAO PRETO \\
\hline 81 & ODONTOBRAS IND. E COM. DE EQ. MED E ODONT LTDA & RIBEIRAO PRETO \\
\hline 82 & ODONTOMEDICS IND DE EQUIP MED ODONTOL & RIBEIRAO PRETO \\
\hline 83 & OLIDEF CZ IND E COM DE AP HOSPITALARES LTDA & RIBEIRAO PRETO \\
\hline 84 & PASTOBRAS SEMENTES LTDA & RIBEIRAO PRETO \\
\hline
\end{tabular}




\begin{tabular}{|c|c|c|}
\hline 85 & PROCION INDÚSTRIA E COMERCIO LTDA & RIBEIRAO PRETO \\
\hline 86 & PRODENTAL EQUIP ODONTOLOGICOS LTDA & RIBEIRAO PRETO \\
\hline 87 & RIBERBALL MERCANTIL E INDUSTRIAL LTDA & RIBEIRAO PRETO \\
\hline 88 & RONCAR IND, COM E EXPORT LTDA. & RIBEIRAO PRETO \\
\hline 89 & SANTA HELENA INDÚSTRIA DE ALIMENTOS S/A & RIBEIRAO PRETO \\
\hline 90 & SANTAL EQUIPAMENTOS S A COM E IND & RIBEIRAO PRETO \\
\hline 91 & SIBRAPE-IND E COM DE ARTIGOS PARA LAZER LTDA & RIBEIRAO PRETO \\
\hline 92 & SOCIEDADE PORTUGUESA DE BENEFICENCIA & RIBEIRAO PRETO \\
\hline 93 & TEC BOL INDÚSTRIA DE ARTEFATOS DE LATEX LTDA. & RIBEIRAO PRETO \\
\hline 94 & TECMEDD IMPORT E DISTRIB DE LIVROS LTDA & RIBEIRAO PRETO \\
\hline SEQ & EMPRESA & CIDADE \\
\hline 95 & TORKFLEX MONT E COM DE ACION MECANICOS & RIBEIRAO PRETO \\
\hline 96 & TRACAN MAQ E SIST PARA AGRICULTURA LTDA & RIBEIRAO PRETO \\
\hline 97 & TUBOS VEROLA COM, IMPORT E EXPORT LTDA. & RIBEIRAO PRETO \\
\hline 98 & UNIBRAS AGRO QUIMICA LTDA & RIBEIRAO PRETO \\
\hline 99 & WEM EQUIPAMENTOS ELETRONICOS LTDA & RIBEIRAO PRETO \\
\hline 100 & WOLF SEEDS DO BRASIL S/A. & RIBEIRAO PRETO \\
\hline 101 & BIO SOJA INDS QUIMICAS E BIOLOGICAS LTDA. & SERRANA \\
\hline 102 & SERRANA PAPEL E CELULOSE S/A & SERRANA \\
\hline 103 & ADDN ASSISTENCIA TECNICA COM E IND LTDA & SERTAOZINHO \\
\hline 104 & BARRA MANSA COM DE CARNES E DERIV LTDA & SERTAOZINHO \\
\hline 105 & COMPANHIA ALBERTINA MERCANTIL E INDUSTRIAL & SERTAOZINHO \\
\hline 106 & COMPANHIA ENERGETICA SANTA ELISA & SERTAOZINHO \\
\hline 107 & DEDINI S/A INDÚSTRIAS DE BASE & SERTAOZINHO \\
\hline 108 & DMB MAQUINAS E IMPLEMENTOS AGRIC LTDA & SERTAOZINHO \\
\hline 109 & ECO-SAND SISTEMAS E EQUIP INDUST - EPP & SERTAOZINHO \\
\hline 110 & EQUIPALCOOL SISTEMAS LTDA & SERTAOZINHO \\
\hline 111 & FERMAN EQUIP INDUST E SERVICOS LTDA & SERTAOZINHO \\
\hline 112 & FERNAVAN COMERCIO INTERNACIONAL LTDA & SERTAOZINHO \\
\hline 113 & FERTRON CONTROLE E AUTOMACAO INDL LTDA & SERTAOZINHO \\
\hline 114 & FUNDICAO MORENO LTDA & SERTAOZINHO \\
\hline 115 & HEROM INDÚSTRIA E COMERCIO LTDA & SERTAOZINHO \\
\hline 116 & INDUSTRIAL PROCESS ENGINEERING LTDA & SERTAOZINHO \\
\hline
\end{tabular}




\begin{tabular}{|c|c|c|}
\hline 117 & INMAD INDÚSTRIA E COMERCIO DE MOVEIS LTDA & SERTAOZINHO \\
\hline 118 & INTERVAL IND E COM DE VALVULAS LTDA & SERTAOZINHO \\
\hline 119 & IRMAOS TONIELLO LTDA & SERTAOZINHO \\
\hline 120 & J W IND E COM DE EQUIP EM ACO INOXIDA & SERTAOZINHO \\
\hline 121 & LAGOA DA SERRA LTDA & SERTAOZINHO \\
\hline 122 & MEGAVAL ACESSORIOS INDUSTRIAIS LTDA & SERTAOZINHO \\
\hline 123 & MERCOSUL REFRATARIOS LTDA. & SERTAOZINHO \\
\hline 124 & MOLBOR - IND E COM DE MOLAS HELICOIDAIS E AR & SERTAOZINHO \\
\hline 125 & NATIVE PROD ORG COML. IMPORT EXPORT LTD & SERTAOZINHO \\
\hline 126 & PROMOEN EQUIPAMENTOS INDUSTRIAIS LTDA & SERTAOZINHO \\
\hline SEQ & EMPRESA & CIDADE \\
\hline 127 & SANDVIK MINING AND CONSTRUCT DO BRASIL S/A & SERTAOZINHO \\
\hline 128 & SERMATEC INDÚSTRIA E MONTAGENS LTDA & SERTAOZINHO \\
\hline 129 & SERT PLAST INDÚSTRIA E COMERCIO LTDA & SERTAOZINHO \\
\hline 130 & SIMEX - SIMIONI IMPORT E EXPORT LTDA. & SERTAOZINHO \\
\hline 131 & SIMISA SIMIONI METALURGICA LTDA & SERTAOZINHO \\
\hline 132 & T.G.M. TURBINAS INDÚSTRIA E COMERCIO LTDA & SERTAOZINHO \\
\hline 133 & UNI SYSTEMS DO BRASIL LTDA & SERTAOZINHO \\
\hline 134 & WAGO PRODUTOS PECUARIOS LTDA EPP & SERTAOZINHO \\
\hline
\end{tabular}




\subsection{Tabelas}

\subsubsection{Análise de Variância (ANOVA)}

Percentual de Faturamento x Informações Utilizadas

Grupo 1: Exporta até 25\% do volume total de vendas anuais

Grupo 2: Exporta de 25\% a 100\% do volume total de vendas anuais 


\begin{tabular}{|c|c|c|c|}
\hline & & ANOVA & \\
\hline & & $\begin{array}{l}\text { Sum of } \\
\text { Squares }\end{array}$ & df \\
\hline Idioma utilizado nas & Between Groups & $1,199 \mathrm{E}-02$ & 1 \\
\hline transaçōes internacionais & Within Groups & 51,065 & 37 \\
\hline & Total & 51,077 & 38 \\
\hline Religião do país alvo & Between Groups & ,154 & 1 \\
\hline & Within Groups & 21,744 & 37 \\
\hline & Total & 21,897 & 38 \\
\hline Taxa de Inflação & Between Groups & 2,266 & 1 \\
\hline & Within Groups & 30,964 & 37 \\
\hline & Total & 33,231 & 38 \\
\hline Taxa de Conversão da & Between Groups & 3,069 & 1 \\
\hline moeda do país alvo $\mathrm{x}$ & Within Groups & 58,623 & 37 \\
\hline 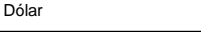 & Total & 61,692 & 38 \\
\hline Renda per Capita & Between Groups & ,481 & 1 \\
\hline & Within Groups & 40,494 & 37 \\
\hline & Total & 40,974 & 38 \\
\hline Volume de Reservas & Between Groups & ,176 & 1 \\
\hline Internacionais & Within Groups & 15,260 & 37 \\
\hline & Total & 15,436 & 38 \\
\hline Produto Interno Bruto & Between Groups & $6,743 \mathrm{E}-03$ & 1 \\
\hline & Within Groups & 23,224 & 37 \\
\hline & Total & 23,231 & 38 \\
\hline Taxa de Desemprego & Between Groups & ,300 & 1 \\
\hline & Within Groups & 12,623 & 37 \\
\hline & Total & 12,923 & 38 \\
\hline Estabilidade Política & Between Groups & 2,849 & 1 \\
\hline & Within Groups & 47,510 & 37 \\
\hline & Total & 50,359 & 38 \\
\hline Relações Diplomáticas & Between Groups & 1,898 & 1 \\
\hline com o Brasil & Within Groups & 53,692 & 37 \\
\hline & Total & 55,590 & 38 \\
\hline Exitência de Acordos & Between Groups & 2,942 & 1 \\
\hline Comerciais com o Brasil & Within Groups & 54,494 & 37 \\
\hline & Total & 57,436 & 38 \\
\hline Concorrentes & Between Groups & 6,667 & 1 \\
\hline Internacionais que atuam & Within Groups & 47,692 & 37 \\
\hline no mercado alvo & Total & 54,359 & 38 \\
\hline Existência de fabricantes & Between Groups & 1,679 & 1 \\
\hline nacionais no mercado & Within Groups & 60,065 & 37 \\
\hline & Total & 61,744 & 38 \\
\hline Estimativa de demanda & Between Groups & 8,366 & 1 \\
\hline do produto no mercado & Within Groups & 45,224 & 37 \\
\hline & Total & 53,590 & 38 \\
\hline Capacidade de & Between Groups & 1,082 & 1 \\
\hline Pagamento dos & Within Groups & 28,610 & 37 \\
\hline compradores & Total & 29,692 & 38 \\
\hline Preço praticado pelos & Between Groups & 5,499 & 1 \\
\hline concorrentes & Within Groups & 32,860 & 37 \\
\hline & Total & 38,359 & 38 \\
\hline Impostos incidentes & Between Groups & ,560 & 1 \\
\hline sobre o seu produto & Within Groups & 57,338 & 37 \\
\hline & Total & 57,897 & 38 \\
\hline Beneficios Fiscais para o & Between Groups & 2,158 & 1 \\
\hline seu produto & Within Groups & 55,432 & 37 \\
\hline & Total & 57,590 & 38 \\
\hline Exigências e Normas & Between Groups & 2,697 & 1 \\
\hline para o seu produto & Within Groups & 37,610 & 37 \\
\hline & Total & 40,308 & 38 \\
\hline Custos Logísticos para & Between Groups & ,883 & 1 \\
\hline seu produto & Within Groups & 62,860 & 37 \\
\hline & Total & 63,744 & 38 \\
\hline Disponibilidade de & Between Groups & ,751 & 1 \\
\hline Transporte para o país & Within Groups & 41,146 & 37 \\
\hline & Total & 41,897 & 38 \\
\hline Procedimentos & Between Groups & $8,525 \mathrm{E}-02$ & 1 \\
\hline Burocrráticos para & Within Groups & 57,351 & 37 \\
\hline importação & Total & 57,436 & 38 \\
\hline Embaixadas/Consulados & Between Groups & ,900 & 1 \\
\hline Brasileiros & Within Groups & 31,766 & 37 \\
\hline & Total & 32,667 & 38 \\
\hline Embaixadas/Consulados & Between Groups & ,560 & 1 \\
\hline Estrangeiros & Within Groups & 37,338 & 37 \\
\hline & Total & 37,897 & 38 \\
\hline Câmaras de Comércio & Between Groups &, 154 & 1 \\
\hline & Within Groups & 23,744 & 37 \\
\hline & Total & 23,897 & 38 \\
\hline Assinatura de Serviços de & Between Groups & 3,706 & 1 \\
\hline Informação & Within Groups & 36,653 & 37 \\
\hline & Total & 40,359 & 38 \\
\hline Publicaçōes & Between Groups & 1,280 & 1 \\
\hline Especializadas & Within Groups & 52,156 & 37 \\
\hline & Total & 53,436 & 38 \\
\hline A empresa tem um & Between Groups & ,918 & 1 \\
\hline stema próprio de & Within Groups & 44,159 & 37 \\
\hline & Total & 45,077 & 38 \\
\hline A empresa contrata & Between Groups & ,385 & 1 \\
\hline serviços de informação & Within Groups & 7,974 & 37 \\
\hline & Total & 8,359 & 38 \\
\hline Feiras Internacionais nos & Between Groups & 1,949 & 1 \\
\hline fornecem informações & Within Groups & 49,744 & 37 \\
\hline necessárias & Total & 51,692 & 38 \\
\hline Os clientes nos enviam & Between Groups & 4,404 & 1 \\
\hline as informacões & Within Groups & 23,494 & 37 \\
\hline necessárias & Total & 27,897 & 38 \\
\hline
\end{tabular}




\subsubsection{Análise Descritiva}

\section{Percentual de Faturamento x Informações Utilizadas}

Grupo 1: Exporta até $25 \%$ do volume total de vendas anuais

Grupo 2: Exporta de 25\% a 100\% do volume total de vendas anuais 


\begin{tabular}{|c|c|c|}
\hline & & \\
\hline & & \\
\hline & & $\mathrm{N}$ \\
\hline \begin{tabular}{|l|} 
Idioma utilizado nas \\
\end{tabular} & Até $25 \%$ & 28 \\
\hline transações internacionais & Acima de $25 \%$ & 11 \\
\hline & Total & 39 \\
\hline Religião do país alvo & Até $25 \%$ & 28 \\
\hline & Acima de $25 \%$ & 11 \\
\hline & Total & 39 \\
\hline Taxa de Inflação & Até $25 \%$ & 28 \\
\hline & Acima de $25 \%$ & 11 \\
\hline & Total & 39 \\
\hline Taxa de Conversão da & Até $25 \%$ & 28 \\
\hline moeda do país alvo $x$ & Acima de $25 \%$ & 11 \\
\hline Dólar & Total & 39 \\
\hline \begin{tabular}{|l|} 
Renda per Capita \\
\end{tabular} & Até $25 \%$ & 28 \\
\hline & Acima de $25 \%$ & 11 \\
\hline & Total & 39 \\
\hline \begin{tabular}{|l|} 
Volume de Reservas \\
\end{tabular} & Até $25 \%$ & 28 \\
\hline Internacionais & Acima de $25 \%$ & 11 \\
\hline & Total & 39 \\
\hline \begin{tabular}{|l|} 
Produto Interno Bruto \\
\end{tabular} & Até $25 \%$ & 28 \\
\hline & Acima de $25 \%$ & 11 \\
\hline & Total & 39 \\
\hline Taxa de Desemprego & Até $25 \%$ & 28 \\
\hline & Acima de $25 \%$ & 11 \\
\hline & Total & 39 \\
\hline Estabilidade Política & Até $25 \%$ & 28 \\
\hline & Acima de $25 \%$ & 11 \\
\hline & Total & 39 \\
\hline Relaçōes Diplomáticas & Até $25 \%$ & 28 \\
\hline com o Brasil & Acima de $25 \%$ & 11 \\
\hline & Total & 39 \\
\hline \begin{tabular}{|l|} 
Exitência de Acordos \\
\end{tabular} & Até $25 \%$ & 28 \\
\hline Comerciais com o Brasil & Acima de $25 \%$ & 11 \\
\hline & Total & 39 \\
\hline \begin{tabular}{|l|} 
Concorrentes \\
\end{tabular} & Até $25 \%$ & 28 \\
\hline Internacionais que atuam & Acima de $25 \%$ & 11 \\
\hline no mercado alvo & Total & 39 \\
\hline \begin{tabular}{|l} 
Existência de fabricantes \\
\end{tabular} & Até $25 \%$ & 28 \\
\hline nacionais no mercado & Acima de $25 \%$ & 11 \\
\hline & Total & 39 \\
\hline \begin{tabular}{|l|} 
Estimativa de demanda \\
\end{tabular} & Até $25 \%$ & 28 \\
\hline do produto no mercado & Acima de $25 \%$ & 11 \\
\hline & Total & 39 \\
\hline Capacidade de & Até $25 \%$ & 28 \\
\hline Pagamento dos & Acima de $25 \%$ & 11 \\
\hline mpradores & Total & 39 \\
\hline Preço praticado pelos & Até $25 \%$ & 28 \\
\hline concorrentes & Acima de $25 \%$ & 11 \\
\hline & Total & 39 \\
\hline Impostos incidentes & Até $25 \%$ & 28 \\
\hline sobre o seu produto & Acima de $25 \%$ & 11 \\
\hline & Total & 39 \\
\hline \begin{tabular}{|l|} 
Benefícios Fiscais para o \\
\end{tabular} & Até $25 \%$ & 28 \\
\hline seu produto & Acima de $25 \%$ & 11 \\
\hline & Total & 39 \\
\hline \begin{tabular}{|l|} 
Exigências e Normas \\
\end{tabular} & Até $25 \%$ & 28 \\
\hline para o seu produto & Acima de $25 \%$ & 11 \\
\hline & Total & 39 \\
\hline \begin{tabular}{|l} 
Custos Logísticos para \\
\end{tabular} & Até $25 \%$ & 28 \\
\hline seu produto & Acima de $25 \%$ & 11 \\
\hline & Total & 39 \\
\hline \begin{tabular}{|l|} 
Disponibilidade de \\
\end{tabular} & Até $25 \%$ & 28 \\
\hline Transporte para o pais & Acima de $25 \%$ & 11 \\
\hline & Total & 39 \\
\hline \begin{tabular}{|l|} 
Procedimentos \\
\end{tabular} & Até $25 \%$ & 28 \\
\hline Burocrráticos para & Acima de $25 \%$ & 11 \\
\hline importação & Total & 39 \\
\hline Embaixadas/Consulados & Até $25 \%$ & 28 \\
\hline Brasileiros & Acima de $25 \%$ & 11 \\
\hline & Total & 39 \\
\hline \begin{tabular}{|l|} 
Embaixadas/Consulados \\
\end{tabular} & Até $25 \%$ & 28 \\
\hline Estrangeiros & Acima de $25 \%$ & 11 \\
\hline & Total & 39 \\
\hline Câmaras de Comércio & Até $25 \%$ & 28 \\
\hline & Acima de $25 \%$ & 11 \\
\hline & Total & 39 \\
\hline Assinatura de Serviços de & Até $25 \%$ & 28 \\
\hline Informação & Acima de $25 \%$ & 11 \\
\hline & Total & 39 \\
\hline \begin{tabular}{|l} 
Publicações \\
\end{tabular} & Até $25 \%$ & 28 \\
\hline Especializadas & Acima de $25 \%$ & 11 \\
\hline & Total & 39 \\
\hline A empresa tem um & Até $25 \%$ & 28 \\
\hline sistema próprio de & Acima de $25 \%$ & 11 \\
\hline squisa & Total & 39 \\
\hline A empresa contrata & Até $25 \%$ & 28 \\
\hline serviços de informação & Acima de $25 \%$ & 11 \\
\hline & Total & 39 \\
\hline \begin{tabular}{|l|} 
Feiras Internacionais nos \\
\end{tabular} & Até $25 \%$ & 28 \\
\hline fornecem informaçōes & Acima de $25 \%$ & 11 \\
\hline cessárias & Total & 39 \\
\hline Os clientes nos enviam & Até $25 \%$ & 28 \\
\hline informacões & Acima de $25 \%$ & 11 \\
\hline nec & Total & 39 \\
\hline
\end{tabular}




\subsubsection{Análise de Variância (ANOVA)}

\section{Percentual de Faturamento x Mercados de Atuação}

Grupo 1: Exporta até $25 \%$ do volume total de vendas anuais

Grupo 2: Exporta de 25\% a 100\% do volume total de vendas anuais

\section{ANOVA}

\begin{tabular}{|c|c|c|c|c|c|c|}
\hline & & $\begin{array}{l}\text { Sum of } \\
\text { Squares }\end{array}$ & $\mathrm{df}$ & $\begin{array}{c}\text { Mean } \\
\text { Square }\end{array}$ & $F$ & Sig. \\
\hline \multirow[t]{3}{*}{ Mercosul } & Between Groups & $8,325 \mathrm{E}-03$ & $\overline{1}$ & $8,325 \mathrm{E}-03$ & ,049 & ,827 \\
\hline & Within Groups & 6,351 & 37 & , 172 & & \\
\hline & Total & 6,359 & 38 & & & \\
\hline \multirow{3}{*}{$\begin{array}{l}\text { America Latina } \\
\text { exceto Mercosul }\end{array}$} & Between Groups & $3,330 \mathrm{E}-02$ & 1 & 3,330E-02 & ,131 & ,719 \\
\hline & Within Groups & 9,403 & 37 & ,254 & & \\
\hline & Total & 9,436 & 38 & & & \\
\hline \multirow[t]{3}{*}{ União Européia } & Between Groups & 1,063 & 1 & 1,063 & 5,755 & ,022 \\
\hline & Within Groups & 6,834 & 37 & , 185 & & \\
\hline & Total & 7,897 & 38 & & & \\
\hline \multirow{3}{*}{$\begin{array}{l}\text { Estados Unidos e } \\
\text { Canada }\end{array}$} & Between Groups & ,520 & 1 &, 520 & 3,680 & ,063 \\
\hline & Within Groups & 5,224 & 37 & , 141 & & \\
\hline & Total & 5,744 & 38 & & & \\
\hline \multirow[t]{3}{*}{ China } & Between Groups & ,587 & 1 & ,587 & 9,962 &, 003 \\
\hline & Within Groups & 2,182 & 37 & 5,897E-02 & & \\
\hline & Total & 2,769 & 38 & & & \\
\hline \multirow[t]{3}{*}{ Asia exceto China } & Between Groups & 1,159 & 1 & 1,159 & 9,355 & ,004 \\
\hline & Within Groups & 4,584 & 37 & , 124 & & \\
\hline & Total & 5,744 & 38 & & & \\
\hline \multirow[t]{3}{*}{ Africa } & Between Groups & ,533 & 1 & ,533 & 2,335 & , 135 \\
\hline & Within Groups & 8,442 & 37 & ,228 & & \\
\hline & Total & 8,974 & 38 & & & \\
\hline \multirow[t]{3}{*}{ Oriente Médio } & Between Groups & 1,159 & 1 & 1,159 & 9,355 & ,004 \\
\hline & Within Groups & 4,584 & 37 & ,124 & & \\
\hline & Total & 5,744 & 38 & & & \\
\hline \multirow[t]{3}{*}{ Outros } & Between Groups & , 169 & 1 & , 169 & 2,398 &, 130 \\
\hline & Within Groups & 2,601 & 37 & 7,029E-02 & & \\
\hline & Total & 2,769 & 38 & & & \\
\hline
\end{tabular}




\subsubsection{Análise Descritiva}

\section{Percentual de Faturamento x Mercados de Atuação}

Grupo 1: Exporta até 25\% do volume total de vendas anuais

Grupo 2: Exporta de 25\% a 100\% do volume total de vendas anuais

Descriptives

\begin{tabular}{|c|c|c|c|c|c|c|c|c|c|}
\hline & \multirow[b]{2}{*}{$\mathrm{N}$} & \multirow[b]{2}{*}{ Mean } & \multirow[b]{2}{*}{$\begin{array}{c}\text { Std. } \\
\text { Deviation }\end{array}$} & \multirow[b]{2}{*}{ Std. Error } & \multicolumn{2}{|c|}{$\begin{array}{l}\text { 95\% Confidence } \\
\text { Interval for Mean }\end{array}$} & \multirow[b]{2}{*}{ Minimum } & \multirow[b]{2}{*}{ Maximum } \\
\hline & & & & & & $\begin{array}{l}\text { Lower } \\
\text { Bound }\end{array}$ & $\begin{array}{l}\text { Upper } \\
\text { Bound }\end{array}$ & & \\
\hline \multirow[t]{3}{*}{ Mercosul } & Até 25\% & 28 & ,7857 & ,4179 & $7,897 \mathrm{E}-02$ & ,6237 & ,9477 &, 00 & 1,00 \\
\hline & Acima de $25 \%$ & 11 & ,8182 & ,4045 & 1220 & ,5464 & 1,0899 & ,00 & 1,00 \\
\hline & Total & 39 & 7949 & 4091 & 6,550E-02 & 6623 & ,9275 & ,00 & 1,00 \\
\hline \multirow{3}{*}{$\begin{array}{l}\text { America Latina } \\
\text { exceto Mercosul }\end{array}$} & Até $25 \%$ & 28 & ,5714 & ,5040 & $9,524 \mathrm{E}-02$ & ,3760 & ,7668 &, 00 & 1,00 \\
\hline & Acima de $25 \%$ & 11 & ,6364 &, 5045 & 1521 & 2974 & ,9753 &, 00 & 1,00 \\
\hline & Total & 39 & ,5897 & 4983 & 7,979E-02 & ,4282 & ,7513 &, 00 & 1,00 \\
\hline \multirow[t]{3}{*}{ União Européia } & Até $25 \%$ & 28 & ,1786 & ,3900 & $7,371 \mathrm{E}-02$ & $2,734 \mathrm{E}-02$ & ,3298 &, 00 & 1,00 \\
\hline & Acima de $25 \%$ & 11 & ,5455 & 5222 & 1575 & 1946 & 8963 & ,00 & 1,00 \\
\hline & Total & 39 & 2821 & 4559 & 7,300E-02 & 1343 & 4298 & ,00 & 1,00 \\
\hline \multirow{3}{*}{$\begin{array}{l}\text { Estados Unidos e } \\
\text { Canada }\end{array}$} & Até $25 \%$ & 28 & ,1071 & ,3150 & 5,952E-02 & $-1,50 \mathrm{E}-02$ & ,2293 &, 00 & 1,00 \\
\hline & Acima de $25 \%$ & 11 & ,3636 &, 5045 & ,1521 & $2,469 \mathrm{E}-02$ & ,7026 &, 00 & 1,00 \\
\hline & Total & 39 & , 1795 & ,3888 & 6,225E-02 & $5,346 \mathrm{E}-02$ & ,3055 &, 00 & 1,00 \\
\hline \multirow[t]{3}{*}{ China } & Até $25 \%$ & 28 & 0000 & 0000 & ,0000 & 0000 &, 0000 &, 00 & 00 \\
\hline & Acima de $25 \%$ & 11 & 2727 & 4671 & 1408 & $-4,11 \mathrm{E}-02$ & ,5865 & ,00 & 1,00 \\
\hline & Total & 39 & 7,692E-02 & 2700 & 4,323E-02 & -1,06E-02 & 1644 & ,00 & 1,00 \\
\hline \multirow[t]{3}{*}{ Asia exceto China } & Até $25 \%$ & 28 & $7,143 \mathrm{E}-02$ & ,2623 & $4,956 \mathrm{E}-02$ & \begin{tabular}{|l|}
$-3,03 E-02$ \\
\end{tabular} & ,1731 &, 00 & 1,00 \\
\hline & Acima de $25 \%$ & 11 & ,4545 & ,5222 & 1575 & 1037 & 8054 &, 00 & 1,00 \\
\hline & Total & 39 & ,1795 & ,3888 & $6,225 \mathrm{E}-02$ & 5,346E-02 & ,3055 &, 00 & 1,00 \\
\hline \multirow[t]{3}{*}{ Africa } & Até $25 \%$ & 28 & ,2857 & ,4600 & 8,694E-02 & ,1073 & ,4641 &, 00 & 1,00 \\
\hline & Acima de $25 \%$ & 11 & ,5455 & 5222 & 1575 & 1946 & 8963 & ,00 & 1,00 \\
\hline & Total & 39 & ,3590 & ,4860 & 7,782E-02 & 2014 &, 5165 & ,00 & 1,00 \\
\hline \multirow[t]{3}{*}{ Oriente Médio } & Até $25 \%$ & 28 & $7,143 \mathrm{E}-02$ & ,2623 & $4,956 \mathrm{E}-02$ & $-3,03 E-02$ & ,1731 &, 00 & 1,00 \\
\hline & Acima de $25 \%$ & 11 & ,4545 & ,5222 & 1575 & 1037 & ,8054 &, 00 & 1,00 \\
\hline & Total & 39 & 1795 & 3888 & $6,225 \mathrm{E}-02$ & $5,346 \mathrm{E}-02$ & ,3055 &, 00 & 1,00 \\
\hline \multirow[t]{3}{*}{ Outros } & Até $25 \%$ & 28 & $3,571 \mathrm{E}-02$ & ,1890 & $3,571 \mathrm{E}-02$ & $-3,76 \mathrm{E}-02$ & , 1090 &, 00 & 1,00 \\
\hline & Acima de $25 \%$ & 11 & 1818 & 4045 & 1220 & $-8,99 \mathrm{E}-02$ & 4536 & ,00 & 1,00 \\
\hline & Total & 39 & 7,692E-02 & 2700 & 4,323E-02 & $-1,06 \mathrm{E}-02$ & 1644 & ,00 & 1,00 \\
\hline
\end{tabular}




\subsubsection{Análise de Variância (ANOVA)}

\section{Percentual de Faturamento x Forma de Atuação}

Grupo 1: Exporta até $25 \%$ do volume total de vendas anuais

Grupo 2: Exporta de $25 \%$ a $100 \%$ do volume total de vendas anuais

ANOVA

\begin{tabular}{|c|c|c|c|c|c|c|}
\hline & & $\begin{array}{l}\text { Sum of } \\
\text { Squares }\end{array}$ & $\mathrm{df}$ & $\begin{array}{c}\text { Mean } \\
\text { Square }\end{array}$ & $\mathrm{F}$ & Sig. \\
\hline Exportação Direta & $\begin{array}{l}\text { Between Groups } \\
\text { Within Groups } \\
\text { Total }\end{array}$ & $\begin{array}{r}, 674 \\
4,403 \\
5,077\end{array}$ & $\begin{array}{r}1 \\
37 \\
38\end{array}$ & $\begin{array}{l}674 \\
, 119\end{array}$ & 5,667 &, 023 \\
\hline $\begin{array}{l}\text { Exporta para } \\
\text { distribuidores próprios }\end{array}$ & $\begin{array}{l}\text { Between Groups } \\
\text { Within Groups } \\
\text { Total }\end{array}$ & $\begin{array}{r}, 243 \\
8,065 \\
8,308 \\
\end{array}$ & $\begin{array}{r}1 \\
37 \\
38\end{array}$ & $\begin{array}{l}243 \\
218\end{array}$ & 1,114 & ,298 \\
\hline $\begin{array}{l}\text { Exporta por agentes } \\
\text { independentes }\end{array}$ & $\begin{array}{l}\text { Between Groups } \\
\text { Within Groups } \\
\text { Total }\end{array}$ & $\begin{array}{r}, 953 \\
5,406 \\
6,359\end{array}$ & $\begin{array}{r}1 \\
37 \\
38\end{array}$ & $\begin{array}{l}, 953 \\
, 146\end{array}$ & 6,524 & ,015 \\
\hline Utiliza Exporta fácil & $\begin{array}{l}\text { Between Groups } \\
\text { Within Groups } \\
\text { Total }\end{array}$ & $\begin{array}{r}9,066 \mathrm{E}-02 \\
2,679 \\
2,769 \\
\end{array}$ & $\begin{array}{r}1 \\
37 \\
38 \\
\end{array}$ & $\begin{array}{l}9,066 \mathrm{E}-02 \\
7,239 \mathrm{E}-02\end{array}$ & 1,252 & ,270 \\
\hline $\begin{array}{l}\text { Empresa busca novos } \\
\text { mercados }\end{array}$ & $\begin{array}{l}\text { Between Groups } \\
\text { Within Groups } \\
\text { Total }\end{array}$ & $\begin{array}{r}, 783 \\
8,653 \\
9,436 \\
\end{array}$ & $\begin{array}{r}1 \\
37 \\
38 \\
\end{array}$ & $\begin{array}{l}, 783 \\
\text {,234 }\end{array}$ & 3,350 & ,075 \\
\hline $\begin{array}{l}\text { Nao busca-clientes é } \\
\text { que procuram }\end{array}$ & $\begin{array}{l}\text { Between Groups } \\
\text { Within Groups } \\
\text { Total }\end{array}$ & $\begin{array}{r}1,199 \mathrm{E}-02 \\
5,065 \\
5,077 \\
\end{array}$ & $\begin{array}{r}1 \\
37 \\
38\end{array}$ & $\begin{array}{r}1,199 \mathrm{E}-02 \\
137\end{array}$ & ,088 & ,769 \\
\hline
\end{tabular}




\subsubsection{Análise Descritiva}

\section{Percentual de Faturamento x Forma de Atuação}

Grupo 1: Exporta até 25\% do volume total de vendas anuais

Grupo 2: Exporta de $25 \%$ a $100 \%$ do volume total de vendas anuais

Descriptives

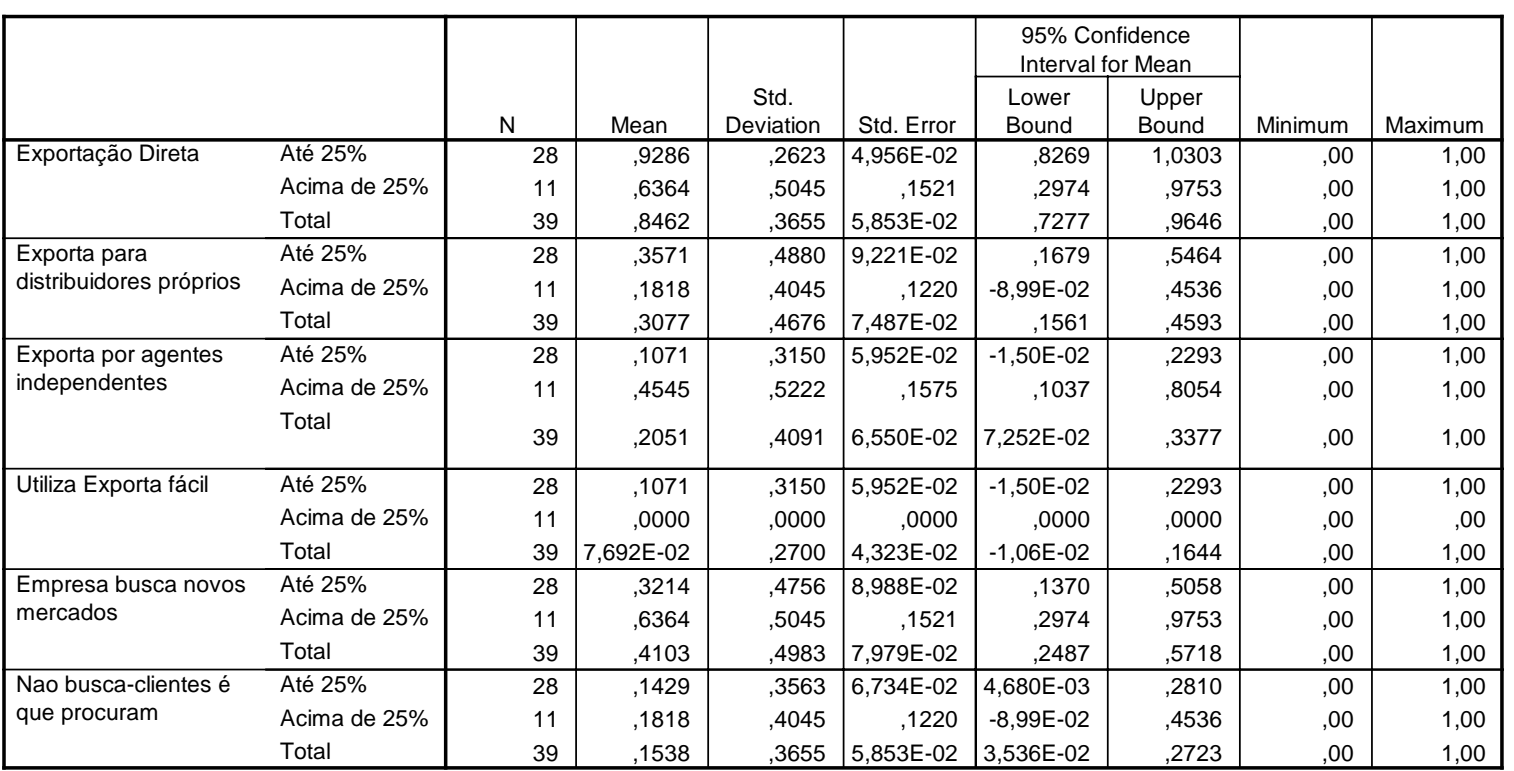

\subsubsection{Análise de Variância (ANOVA)}

\section{Grupo que busca novos mercados x Informações Utilizadas}

0: Busca Novos Mercados

1: Não busca novos mercados 
ANOVA

\begin{tabular}{|c|c|c|c|c|c|c|}
\hline & & $\begin{array}{l}\text { Sum of } \\
\text { Squares }\end{array}$ & df & $\begin{array}{l}\text { Mean } \\
\text { Square }\end{array}$ & $\mathrm{F}$ & Sig. \\
\hline \multirow{3}{*}{$\begin{array}{l}\text { Idioma utilizado nas } \\
\text { transações } \\
\text { internacionais }\end{array}$} & Between Groups & 1,270 & 1 & 1,270 & \multirow[t]{3}{*}{,943 } & \multirow[t]{3}{*}{, 338} \\
\hline & Within Groups & 49,807 & 37 & 1,346 & & \\
\hline & Total & 51,077 & 38 & & & \\
\hline \multirow[t]{3}{*}{ Religião do país alvo } & Between Groups & 4,460 & 1 & 4,460 & \multirow[t]{3}{*}{9,463} & \multirow[t]{3}{*}{,004 } \\
\hline & Within Groups & 17,438 & 37 & ,471 & & \\
\hline & Total & 21,897 & 38 & & & \\
\hline \multirow[t]{3}{*}{ Taxa de Inflação } & Between Groups & 1,829 & 1 & 1,829 & \multirow[t]{3}{*}{2,155} & \multirow[t]{3}{*}{ 151 } \\
\hline & Within Groups & 31,402 & 37 & ,849 & & \\
\hline & Total & 33,231 & 38 & & & \\
\hline \multirow{3}{*}{$\begin{array}{l}\text { Taxa de Conversão da } \\
\text { moeda do país alvo x } \\
\text { Dólar }\end{array}$} & Between Groups & 1,385 & 1 & 1,385 & \multirow[t]{3}{*}{,850 } & \multirow[t]{3}{*}{,363 } \\
\hline & Within Groups & 60,307 & 37 & 1,630 & & \\
\hline & Total & 61,692 & 38 & & & \\
\hline Renda per Capita & Between Groups & 3,496 & 1 & 3,496 & 3,451 & ,071 \\
\hline & Within Groups & 37,478 & 37 & 1,013 & & \\
\hline & Total & 40,974 & 38 & & & \\
\hline Volume de Reservas & Between Groups & 1,610 & 1 & 1,610 & 4,308 & 045 \\
\hline Internacionais & Within Groups & 13,826 & 37 & ,374 & & \\
\hline & Total & 15,436 & 38 & & & \\
\hline Produto Interno Bruto & Between Groups & 2,489 & 1 & 2,489 & 4,440 & ,042 \\
\hline & Within Groups & 20,742 & 37 &, 561 & & \\
\hline & Total & 23,231 & 38 & & & \\
\hline Taxa de Desemprego & Between Groups & ,564 & 1 & ,564 & 1,690 & ,202 \\
\hline & Within Groups & 12,359 & 37 & 334 & & \\
\hline & Total & 12,923 & 38 & & & \\
\hline Estabilidade Política & Between Groups & 6,313 & 1 & 6,313 & 5,303 & , 027 \\
\hline & Within Groups & 44,046 & 37 & 1,190 & & \\
\hline & Total & 50,359 & 38 & & & \\
\hline Relações Diplomáticas & Between Groups & 9,283 & 1 & 9,283 & 7,417 & ,010 \\
\hline com o Brasil & Within Groups & 46,307 & 37 & 1,252 & & \\
\hline & Total & 55,590 & 38 & & & \\
\hline Exitência de Acordos & Between Groups & 3,947 & 1 & 3,947 & 2,730 & , 107 \\
\hline Comerciais com o Brasil & Within Groups & 53,489 & 37 & 1,446 & & \\
\hline & Total & 57,436 & 38 & & & \\
\hline Concorrentes & Between Groups & 5,620 & 1 & 5,620 & 4,266 & ,046 \\
\hline Internacionais que & Within Groups & 48,739 & 37 & 1,317 & & \\
\hline atuam no mercado alvo & Total & 54,359 & 38 & & & \\
\hline Existência de fabricantes & Between Groups & 1,874 & 1 & 1,874 & 1,158 & , 289 \\
\hline nacionais no mercado & Within Groups & 59,870 & 37 & 1,618 & & \\
\hline alvo & Total & 61,744 & 38 & & & \\
\hline Estimativa de demanda & Between Groups & 3,372 & 1 & 3,372 & 2,485 & ,123 \\
\hline do produto no mercado & Within Groups & 50,217 & 37 & 1,357 & & \\
\hline & Total & 53,590 & 38 & & & \\
\hline Capacidade de & Between Groups & 4,013E-02 & 1 & $4,013 \mathrm{E}-02$ & 050 & ,824 \\
\hline Pagamento dos & Within Groups & 29,652 & 37 & ,801 & & \\
\hline compradores & Total & 29,692 & 38 & & & \\
\hline Preço praticado pelos & Between Groups & 1,652 & 1 & 1,652 & 1,666 & ,205 \\
\hline concorrentes & Within Groups & 36,707 & 37 & ,992 & & \\
\hline & Total & 38,359 & 38 & & & \\
\hline Impostos incidentes & Between Groups & 3,221 & 1 & 3,221 & 2,180 & , 148 \\
\hline sobre o seu produto & Within Groups & 54,677 & 37 & 1,478 & & \\
\hline & Total & 57,897 & 38 & & & \\
\hline Benefícios Fiscais para & Between Groups & ,196 & 1 & , 196 & , 126 & ,724 \\
\hline o seu produto & Within Groups & 57,394 & 37 & 1,551 & & \\
\hline & Total & 57,590 & 38 & & & \\
\hline Exigências e Normas & Between Groups & $9,030 \mathrm{E}-02$ & 1 & $9,030 \mathrm{E}-02$ & ,083 & ,775 \\
\hline para o seu produto & Within Groups & 40,217 & 37 & 1,087 & & \\
\hline & Total & 40,308 & 38 & & & \\
\hline Custos Logísticos para & Between Groups & 5,502 & 1 & 5,502 & 3,495 & ,069 \\
\hline seu produto & Within Groups & 58,242 & 37 & 1,574 & & \\
\hline & Total & 63,744 & 38 & & & \\
\hline Disponibilidade de & Between Groups & $3,414 \mathrm{E}-03$ & 1 & $3,414 \mathrm{E}-03$ & ,003 & ,957 \\
\hline Transporte para o país & Within Groups & 41,894 & 37 & 1,132 & & \\
\hline alv & Total & 41,897 & 38 & & & \\
\hline Procedimentos & Between Groups & 1,020 & 1 & 1,020 & 669 & ,419 \\
\hline Burocrráticos para & Within Groups & 56,416 & 37 & 1,525 & & \\
\hline Impo & Total & 57,436 & 38 & & & \\
\hline
\end{tabular}




\subsubsection{Análise Descritiva}

\section{Grupo que busca novos mercados $x$ Informações Utilizadas}

0: Busca Novos Mercados

1: Não busca novos mercados 
Descriptives






\title{
8.4.9. Análise de Variância (ANOVA)
}

\section{Grupo que busca novos mercados x Mercados de Atuação}

\author{
0: Busca Novos Mercados
}

1: Não busca novos mercados

ANOVA

\begin{tabular}{|c|c|c|c|c|c|c|}
\hline & & $\begin{array}{l}\text { Sum of } \\
\text { Squares }\end{array}$ & df & $\begin{array}{l}\text { Mean } \\
\text { Square }\end{array}$ & $\mathrm{F}$ & Sig. \\
\hline \multirow[t]{3}{*}{ Mercosul } & Between Groups & 174 & 1 & ,174 & 1,042 & ,314 \\
\hline & Within Groups & 6,185 & 37 & 167 & & \\
\hline & Total & 6,359 & 38 & & & \\
\hline \multirow{3}{*}{$\begin{array}{l}\text { America Latina } \\
\text { exceto Mercosul }\end{array}$} & Between Groups & ,697 & 1 & ,697 & 2,950 & ,094 \\
\hline & Within Groups & 8,739 & 37 & 236 & & \\
\hline & Total & 9,436 & 38 & & & \\
\hline \multirow[t]{3}{*}{ União Européia } & Between Groups & ,656 & 1 & ,656 & 3,350 & ,075 \\
\hline & Within Groups & 7,242 & 37 & 196 & & \\
\hline & Total & 7,897 & 38 & & & \\
\hline \multirow{3}{*}{$\begin{array}{l}\text { Estados Unidos e } \\
\text { Canada }\end{array}$} & Between Groups & 1,742E-03 & 1 & $1,742 \mathrm{E}-03$ & 011 & ,916 \\
\hline & Within Groups & 5,742 & 37 & 155 & & \\
\hline & Total & 5,744 & 38 & & & \\
\hline \multirow[t]{3}{*}{ China } & Between Groups & 332 & 1 & 332 & 5,036 & ,031 \\
\hline & Within Groups & 2,438 & 37 & $6,588 \mathrm{E}-02$ & & \\
\hline & Total & 2,769 & 38 & & & \\
\hline \multirow[t]{3}{*}{ Asia exceto China } & Between Groups & 1,037 & 1 & 1,037 & 8,153 & ,007 \\
\hline & Within Groups & 4,707 & 37 & 127 & & \\
\hline & Total & 5,744 & 38 & & & \\
\hline \multirow[t]{3}{*}{ Africa } & Between Groups &, 540 & 1 &, 540 & 2,367 & ,132 \\
\hline & Within Groups & 8,435 & 37 & 228 & & \\
\hline & Total & 8,974 & 38 & & & \\
\hline \multirow[t]{3}{*}{ Oriente Médio } & Between Groups & 1,037 & 1 & 1,037 & 8,153 & ,007 \\
\hline & Within Groups & 4,707 & 37 & ,127 & & \\
\hline & Total & 5,744 & 38 & & & \\
\hline \multirow[t]{3}{*}{ Outros } & Between Groups & $6,271 \mathrm{E}-02$ & 1 & $6,271 \mathrm{E}-02$ & 857 & ,361 \\
\hline & Within Groups & 2,707 & 37 & 7,315E-02 & & \\
\hline & Total & 2,769 & 38 & & & \\
\hline
\end{tabular}




\title{
8.4.10. Análise Descritiva
}

\section{Grupo que busca novos mercados x Mercados de Atuação}

\author{
0: Busca Novos Mercados
}

1: Não busca novos mercados

Descriptives

\begin{tabular}{|c|c|c|c|c|c|c|c|c|c|}
\hline & \multirow[b]{2}{*}{$\mathrm{N}$} & \multirow[b]{2}{*}{ Mean } & \multirow[b]{2}{*}{$\begin{array}{c}\text { Std. } \\
\text { Deviation }\end{array}$} & \multirow[b]{2}{*}{ Std. Error } & \multicolumn{2}{|c|}{$\begin{array}{l}\text { 95\% Confidence } \\
\text { Interval for Mean }\end{array}$} & \multirow[b]{2}{*}{ Minimum } & \multirow[b]{2}{*}{ Maximum } \\
\hline & & & & & & $\begin{array}{l}\text { Lower } \\
\text { Bound }\end{array}$ & $\begin{array}{l}\text { Upper } \\
\text { Bound }\end{array}$ & & \\
\hline \multirow[t]{3}{*}{ Mercosul } &, 00 & 23 & ,7391 &, 4490 & $9,362 \mathrm{E}-02$ &, 5450 & ,9333 &, 00 & 1,00 \\
\hline & 1,00 & 16 & 8750 & ,3416 & $8,539 \mathrm{E}-02$ & 6930 & 1,0570 &, 00 & 1,00 \\
\hline & Total & 39 & 7949 & ,4091 & $6,550 \mathrm{E}-02$ & ,6623 & ,9275 & , 00 & 1,00 \\
\hline \multirow{3}{*}{$\begin{array}{l}\text { America Latina } \\
\text { exceto Mercosul }\end{array}$} & ,00 & 23 & ,4783 & ,5108 & , 1065 & ,2574 & ,6991 & ,00 & 1,00 \\
\hline & 1,00 & 16 & ,7500 & ,4472 & , 1118 & ,5117 & ,9883 & ,00 & 1,00 \\
\hline & Total & 39 & ,5897 & 4983 & 7,979E-02 & ,4282 &, 7513 & ,00 & 1,00 \\
\hline \multirow[t]{3}{*}{ União Européia } & ,00 & 23 & ,1739 & ,3876 & $8,081 \mathrm{E}-02$ & $6,322 \mathrm{E}-03$ & ,3415 & ,00 & 1,00 \\
\hline & 1,00 & 16 & ,4375 & ,5123 & , 1281 & 1645 & ,7105 &, 00 & 1,00 \\
\hline & Total & 39 & 2821 & 4559 & 7,300E-02 & 1343, & ,4298 & ,00 & 1,00 \\
\hline \multirow{3}{*}{$\begin{array}{l}\text { Estados Unidos e } \\
\text { Canada }\end{array}$} & ,00 & 23 & ,1739 & ,3876 & $8,081 \mathrm{E}-02$ & $6,322 \mathrm{E}-03$ & 3415 & ,00 & 1,00 \\
\hline & 1,00 & 16 & 1875 & 4031 & ,1008 & $-2,73 E-02$ & ,4023 &, 00 & 1,00 \\
\hline & Total & 39 & 1795 & ,3888 & $6,225 \mathrm{E}-02$ & 5,346E-02 & ,3055 & , 00 & 1,00 \\
\hline \multirow[t]{3}{*}{ China } & ,00 & 23 & ,0000 & ,0000 & ,0000 & ,0000 & 0000 & ,00 & ,00 \\
\hline & 1,00 & 16 & 1875 & 4031 & 1008 & $-2,73 E-02$ & ,4023 &, 00 & 1,00 \\
\hline & Total & 39 & 7,692E-02 & ,2700 & 4,323E-02 & $-1,06 \mathrm{E}-02$ & ,1644 & ,00 & 1,00 \\
\hline \multirow[t]{3}{*}{ Asia exceto China } & ,00 & 23 & $4,348 \mathrm{E}-02$ & ,2085 & $4,348 \mathrm{E}-02$ & -4,67E-02 & ,1336 & ,00 & 1,00 \\
\hline & 1,00 & 16 & ,3750 &, 5000 & 1250 & 1086 & ,6414 &, 00 & 1,00 \\
\hline & Total & 39 & 1795 & ,3888 & $6,225 \mathrm{E}-02$ & 5,346E-02 & ,3055 &, 00 & 1,00 \\
\hline \multirow[t]{3}{*}{ Africa } & ,00 & 23 & ,2609 & ,4490 & $9,362 \mathrm{E}-02$ & 6,672E-02 & ,4550 & ,00 & 1,00 \\
\hline & 1,00 & 16 &, 5000 & ,5164 & , 1291 & 2248 & ,7752 &, 00 & 1,00 \\
\hline & Total & 39 & ,3590 & ,4860 & 7,782E-02 & 2014 & ,5165 &, 00 & 1,00 \\
\hline \multirow[t]{3}{*}{ Oriente Médio } & ,00 & 23 & $4,348 \mathrm{E}-02$ & ,2085 & $4,348 \mathrm{E}-02$ & -4,67E-02 & ,1336 & ,00 & 1,00 \\
\hline & 1,00 & 16 & ,3750 &, 5000 & ,1250 & 1086 & ,6414 &, 00 & 1,00 \\
\hline & Total & 39 & , 1795 & ,3888 & 6,225E-02 & 5,346E-02 & ,3055 &, 00 & 1,00 \\
\hline \multirow[t]{3}{*}{ Outros } & ,00 & 23 & $4,348 \mathrm{E}-02$ & 2085 & $4,348 \mathrm{E}-02$ & $-4,67 \mathrm{E}-02$ & ,1336 & ,00 & 1,00 \\
\hline & 1,00 & 16 & 1250 & ,3416 & 8,539E-02 & $-5,70 \mathrm{E}-02$ & ,3070 &, 00 & 1,00 \\
\hline & Total & 39 & 7,692E-02 & 2700 & 4,323E-02 & -1,06E-02 & ,1644 & ,00 & 1,00 \\
\hline
\end{tabular}




\subsubsection{Análise de Variância (ANOVA)}

\section{Grupo que busca novos mercados $x$ Tempo de Atuação}

0: Busca Novos Mercados

1: Não busca novos mercados

ANOVA

ANOSEXP
\begin{tabular}{|l|r|r|r|r|r|}
\hline & \multicolumn{1}{|c|}{$\begin{array}{c}\text { Sum of } \\
\text { Squares }\end{array}$} & df & $\begin{array}{c}\text { Mean } \\
\text { Square }\end{array}$ & F & Sig. \\
\hline Between Groups & 238,469 & 1 & 238,469 & 3,825 &, 058 \\
Within Groups & 2306,967 & 37 & 62,350 & & \\
Total & 2545,436 & 38 & & & \\
\hline
\end{tabular}

\subsubsection{Análise Descritiva}

\section{Grupo que busca novos mercados x Tempo de Atuação}

0: Busca Novos Mercados

1: Não busca novos mercados

\section{Descriptives}

ANOSEXP

\begin{tabular}{|c|c|c|c|c|c|c|c|c|}
\hline & \multirow[b]{2}{*}{$\mathrm{N}$} & \multirow[b]{2}{*}{ Mean } & \multirow[b]{2}{*}{$\begin{array}{c}\text { Std. } \\
\text { Deviation }\end{array}$} & \multirow[b]{2}{*}{ Std. Error } & \multicolumn{2}{|c|}{$\begin{array}{l}95 \% \text { Confidence } \\
\text { Interval for Mean }\end{array}$} & \multirow[b]{2}{*}{ Minimum } & \multirow[b]{2}{*}{ Maximum } \\
\hline & & & & & $\begin{array}{l}\text { Lower } \\
\text { Bound }\end{array}$ & $\begin{array}{l}\text { Upper } \\
\text { Bound }\end{array}$ & & \\
\hline ,00 & 23 & 7,3478 & 6,0724 & 1,2662 & 4,7219 & 9,9737 & 1,00 & 23,00 \\
\hline 1,00 & 16 & 12,3750 & 9,9858 & 2,4965 & 7,0539 & 17,6961 & 3,00 & 37,00 \\
\hline Total & 39 & 9,4103 & 8,1844 & 1,3106 & 6,7572 & 12,0633 & 1,00 & 37,00 \\
\hline
\end{tabular}




\subsubsection{Histogramas}

\section{Grupo que busca novos mercados x Tempo de Atuação}

0: Busca Novos Mercados

1: Não busca novos mercados

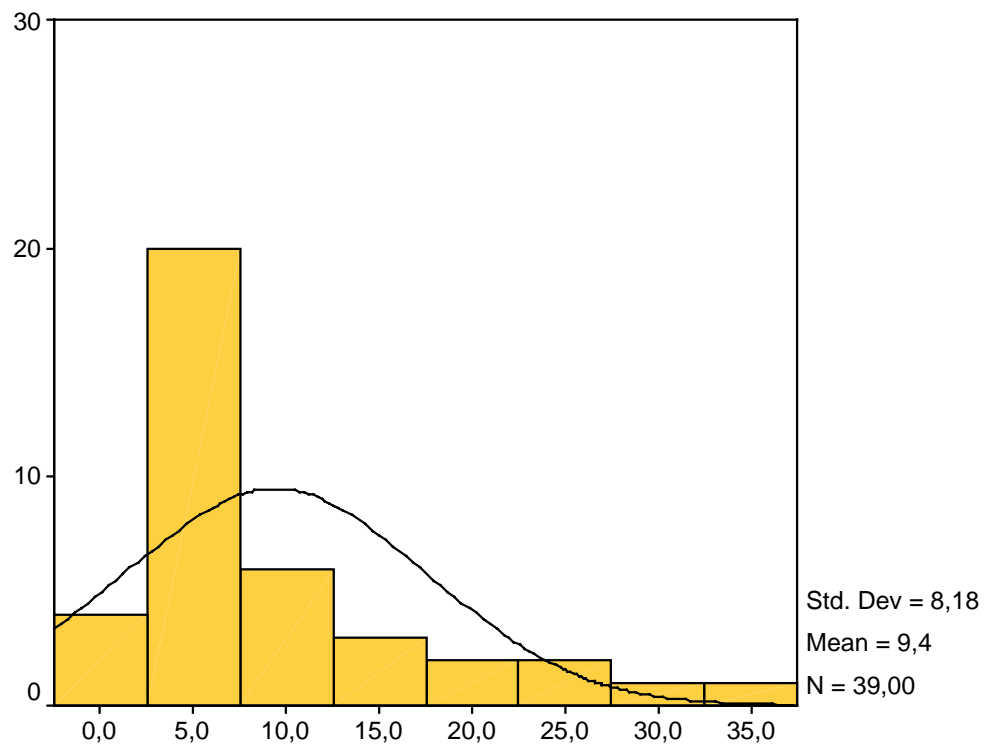

Numero de anos que a empresa exporta

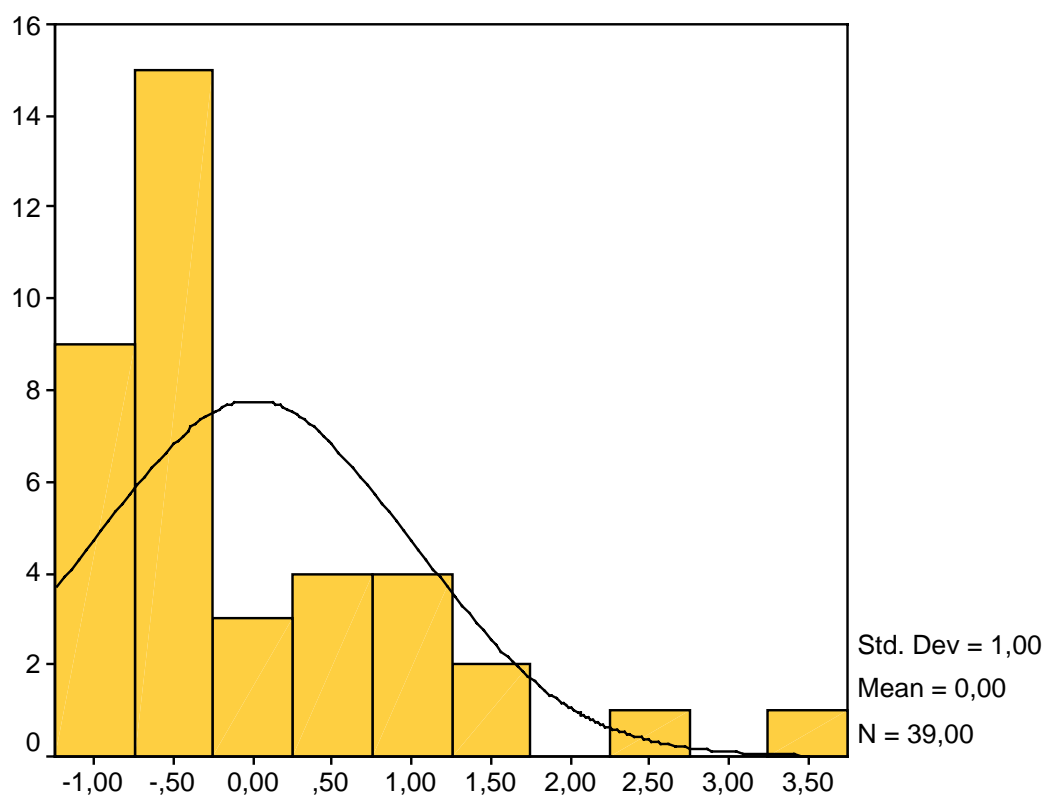

Zscore: Numero de anos que a empresa ex 